\title{
ENRIQUECIMENTO DE CONSÓRCIOS MICROBIANOS EM QUIMIOSTATOS SOB CONDIÇÕES ANAMMOX
}

Tiago Henrique Martins

Dissertação apresentada ao Departamento de hidráulica e Saneamento como parte dos requisitos para obtenção do Título de Mestre em Hidráulica e Saneamento.

Orientadora: Profa. Dra. Maria Bernadete Amâncio Varesche Silva 
AUTORIZO A REPRODUÇÃO E DIVULGAÇÃO TOTAL OU PARCIAL DESTE TRABALHO, POR QUALQUER MEIO CONVENCIONAL OU ELETRÔNICO, PARA FINS DE ESTUDO E PESQUISA, DESDE QUE CITADA A FONTE.

Ficha catalográfica preparada pela Seção de Tratamento da Informação do Serviço de Biblioteca - EESC/USP

Martins, Tiago Henrique
Enriquecimento de consórcios microbianos em
quimiostatos sob condiçoses anammox / Tiago Henrique
Martins ; orientadora Maria Bernadete Amâncio Varesche
Silva. -- São Carlos, 2007 .
Dissertação (Mestrado-Programa de Pós-Graduação e Área
de Concentraço em Hidráulica e Saneamento) -- Escola de
Engenharia de São Carlos da Universidade de São Paulo,
2007.
1. Tratamento de águas residuárias. 2. Anammox.
3. DGGE. 4. Nitrogênio. 5. Quimiostatos. 6. Fish.
I. Título.


Candidato: Bacharel TIAGO HENRIQUE MARTINS

Disserlação defendida e julgada em 13/04/2007 perante a Comissão Julgadora:
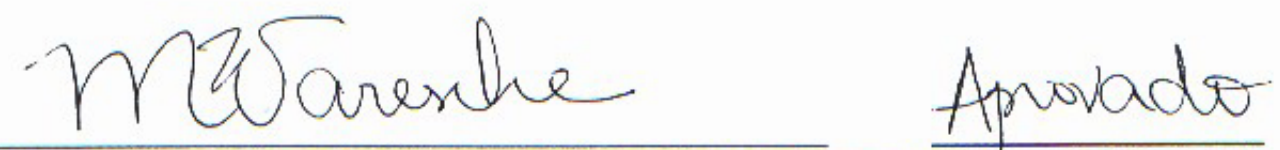

Prof $^{\underline{a}}$. Dr ${ }^{3}$. MARIA BERNADETE AMANCIO VARESCHE SILVA (Orientadora) (Escola de Engenhariacde São Carlos/USP)

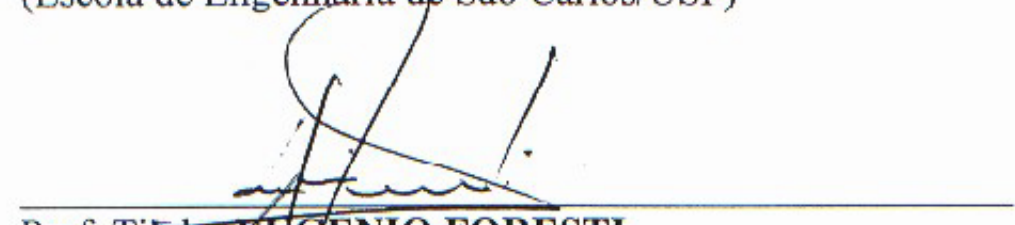

\section{Prof. Titutar EC QENIO FORESTI}

(Escola de Enganharia de São Carlos/USP)
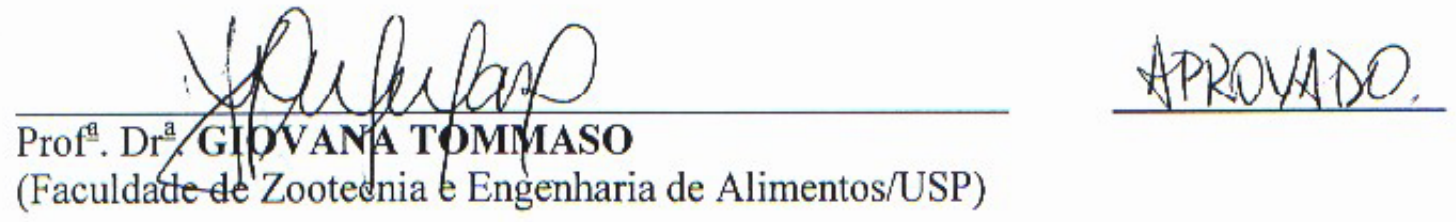

(Faculdacte de Zootednia Engenharia de Alimentos/USP)

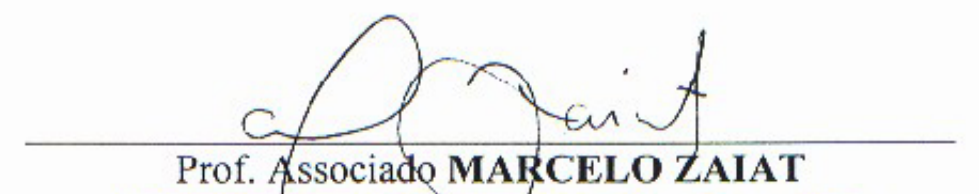

Coordenador do Programa de Pós-Graduação

em Engenharia (Hidráulica e Saneamento)

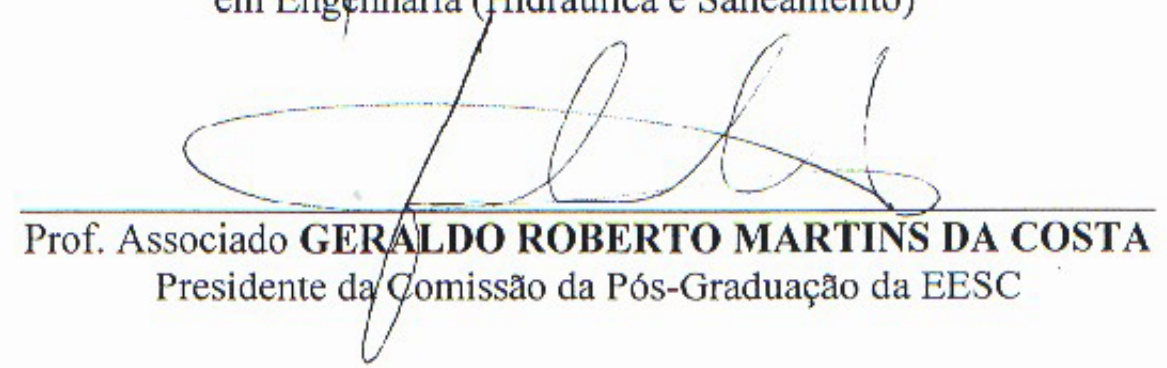


Dedico este trabalho às minhas duas avós Rosa Defavari Polizel e Virgínia Doriguelo Martins, pela simplicidade de suas vidas e por serem as raízes de tudo. 


\section{AGRADECIMENTOS}

À minha querida esposa Lis pelo Amor e Solidariedade na vida ao seu lado e a minha filha Sofia pela paciência e apoio na confecção deste "livro".

À querida orientadora Professora Maria Bernadete pelo exemplo de vida acadêmico e incentivo profissional. Obrigado!

Ao Professor Eugênio Foresti pelas considerações na qualificação e incentivo durante o mestrado.

À Janja, Beth e Elô pela amizade e colaboração “infindáveis".

Aos "Bacanões" Arnaldo, Luis e Leonardo pelos bons momentos no cafezinho regados a discussões altamente construtivas.

À Dani pela força e colaboração na biologia molecular e ao Daniel pelos ensinamentos em construções de árvores filogenéticas.

À Julia pelos ensinamentos na técnica do FISH.

Às minhas amigas de turma do mestrado e laboratório Érika e Carol.

À equipe de pesquisadores do LPB Mércia, Gunther, Iolanda, Lorena, Katita, Sandra, Renata, Lissa, Joel, Flávia, Alexandre Ono, Alexandre Struzziatto, Bruna, Luciano, a turma da iniciação científica.

Às secretárias do departamento Sá e Pavi, em especial à recepcionista Rose pelo bom humor e disposição em sempre ajudar.

À Professora Valéria Reginatto Spiller pelas amostras anammox utilizadas como controle positivo nos ensaios de FISH.

Ao meu Grande amigo Virgílio Teixeira Machado pela amizade soberana.

Em especial aos meus pais André Martins e Maria Angélica Polizel Martins por sempre me apoiarem e incentivarem na vida científica.

À Fundação de Amparo a Pesquisa do Estado de São Paulo (FAPESP) pela concessão da bolsa de estudos, processo 04/12236-0.

Obrigado a todos que participa(ra)m da minha não glamurosa, porém muito prazerosa vida científica. 
MARTINS, T.H. (2007). Enriquecimento de consórcios microbianos em quimiostatos sob condições anammox. São Carlos, 2007. 58p Dissertação (Mestrado) Escola de Engenharia de São Carlos, Universidade de São Paulo.

\section{RESUMO}

Esta pesquisa objetivou enriquecer e purificar, em quimiostatos, consórcios microbianos capazes de oxidar amônia a nitrogênio $\left(\mathrm{N}_{2}\right)$, sob condições anaeróbias utilizando como inóculo: (Q1) biomassa de reator nitrificante-desnitrificante de estação de tratamento de água residuária de indústria produtora de aminoácidos (Ajinomoto) e (Q2) lodo granular de reator UASB de abatedouro de aves (Avícola DACAR, TIETÊ). Os inóculos foram enriquecidos em quimiostatos com vazão afluente de $18 \mathrm{ml} / \mathrm{h}$ de meio basal especifico com concentrações médias de $80 \mathrm{mg} \mathrm{N}-\mathrm{NH}_{4}{ }^{+} / \mathrm{L}, 75,2 \mathrm{mg} \mathrm{N}-\mathrm{NO}_{2}{ }^{-} / \mathrm{L}$ e $1000 \mathrm{mg} / 1$ de bicarbonato como única fonte de carbono. Nos quimiostatos Q1 e Q2 as eficiências médias de remoção foram de $51,6 \%$ e $39,3 \%$ de amônia e $60,5 \%$ e $53,2 \%$ de nitrito, respectivamente, após 296 dias de operação. A eficiência média de remoção de nitrogênio total $\left(\mathrm{N}_{-} \mathrm{NH}_{4}{ }^{+}+\mathrm{N}^{-\mathrm{NO}_{2}}{ }^{-}\right)$foi de 57,1\% e 43\% após 296 dias de operação, respectivamente para Q1 e Q2. A purificação dos consórcios enriquecidos foi realizada utilizando-se metodologia de gradiente de densidade por centrifugação Percoll. Os consórcios microbianos foram observados por exames microscópicos e a diversidade foi avaliada por DGGE antes e depois da purificação pelo protocolo Percoll. O DGGE revelou mudança na estrutura dos consórcios presentes em Q1 e Q2 no decorrer do período de operação dos quimiostatos. A técnica de hibridação in situ (FISH) com sonda fluorescente (Amx - 368) confirmou a presença de microrganismos anammox nos dois consórcios microbianos. O seqüenciamento do DNA ribossomal $16 \mathrm{~S}$ de bandas obtidas do gel de DGGE, utilizando-se primers universais para Domínio Bacteria, relacionou por árvore de máxima verossimilhança, duas bandas com o grupo das Bactérias verdes não-sulfurosas.

Palavras-chaves: Anammox, DGGE, nitrogênio, quimiostatos, FISH. 
MARTINS, T.H. (2007). Enrichment of microbial trusts in chemostats with anammox conditions. São Carlos, 2007. 58p Dissertation (Master) - Escola de Engenharia de São Carlos, Universidade de São Paulo.

\section{ABSTRACT}

This research aimed to enrich and to purify, in chemostats, microbial trusts capable to realize ammonium oxidation to dinitrogen $\left(\mathrm{N}_{2}\right)$ under anaerobic conditions, using as inoculum: (Q1) biomass from nitrifying-denitrifying reactor of wastewater treatment plant of amino-acids industry (Ajinomoto) and (Q2) granular sludge from upflow anaerobic sludge blanket UASB reactor treating poultry wastes - Avícola DACAR, TIETE. The inoculum was enriched in chemostats with affluent flow of $18 \mathrm{ml} / \mathrm{h}$ of specific basal media with mean concentrations of $80 \mathrm{mg} \mathrm{N}-\mathrm{NH}_{4}{ }^{+} / \mathrm{L}, 75.2 \mathrm{mg} \mathrm{NO}_{2}{ }^{-} / \mathrm{L}$ and $1000 \mathrm{mg} / 1$ of bicarbonate as sole carbon source. In Q1 and Q2 chemostats the mean efficiency of removal were $51.6 \%$ and $39.3 \%$ of ammonium, and $60.5 \%$ and $53.2 \%$ of nitrite, respectively, after 296 days of operation. In Q1 and Q2 chemostats, the mean efficiency of total nitrogen removal $\left(\mathrm{N}^{-N H} 4^{+}+\mathrm{NO}_{2}{ }^{-}\right)$were $57.1 \%$ and $43 \%$, respectively, after 296 days of operation. The purification of enriched microbial trusts was carried following methodology of density gradient by centrifugation (Percoll). The microbial trusts were observed by microscopic analysis and the diversity was evaluated by DGGE, before and after the purification by the Percoll protocol. The DGGE analysis showed changes in microbial trusts structure in Q1 and Q2 in chemostats operation period. The fluorescence in situ hibridization technique (FISH) with Amx-368 probe confirmed the presence of anammox microrganisms in both microbial trusts. The sequencing of recovered bands of DGGE was carried through ribossomal DNA 16S using universal primers for Bacteria Domain that related two bands with green nosulphur Bacterium using maximum likelyhood tree.

Keywords: Anammox, DGGE, nitrogen, chemostats, FISH. 


\section{LISTA DE FIGURAS}

Figura 3.1. Esquema do catabolismo anammox. $\mathrm{NIR}=$ nitrito redutase, $\mathrm{HH}=$ hidrazina

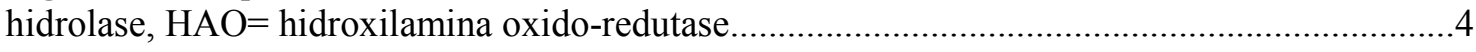

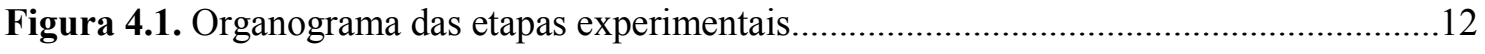

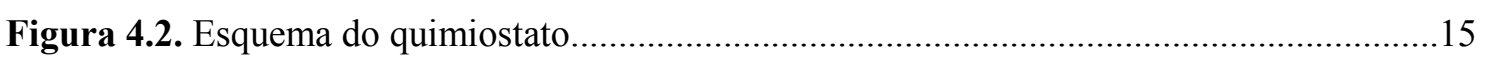

Figura 4.3. Microscopia óptica de campo claro da superfície das pérolas de vidro após ataque

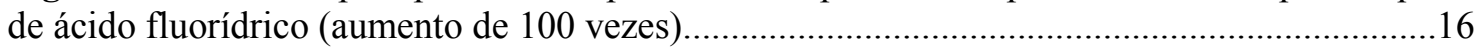

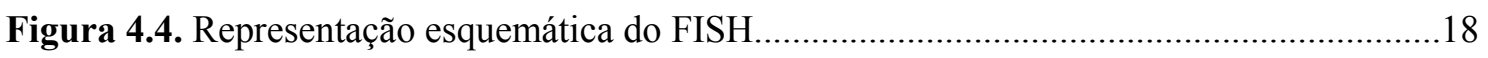

Figura 4.5. Fluxograma da análise dos consórcios microbianos presentes em Q1 e Q2 utilizando técnica PCR/DGGE

Figura 5.1. Microscopia de contraste de fase da biomassa crescida em Q1 com 70 dias de operação..

Figura 5.2. Microscopia de contraste de fase da biomassa crescida em Q1 com 105 dias: (a) cocos agrupados; (b) bacilos sem divisão completa.

Figura 5.3. Microscopia de contraste de fase da biomassa crescida em Q1 com 105 dias: (a) cocos agrupados; (b) coco-bacilos e cocos em matriz extracelular.....

Figura 5.4. Microscopia de contraste de fase da biomassa crescida em Q1 com 109 dias: (a) matriz extracelular rompida; (b) novos aglomerados se formando; (c) bacilos sem divisão completa; (d) cocos aglomerados.

Figura 5.5. Coloração de Gram em microscopia de campo claro da biomassa crescida em Q1 com 148 dias.

Figura 5.6. Microscopia de contraste de fase da biomassa crescida em Q2 com 70 dias de operação.

Figura 5.7. Microscopia de contraste de fase da biomassa crescida em Q2 com 105 dias: (a) bacilos pleomórficos; (b) bacilos sem divisão completa; (c) biofilme de células aglomeradas; (d) cocos agrupados

Figura 5.8. Microscopia de contraste de fase da biomassa crescida em Q2 com 109 dias.........27

Figura 5.9. Microscopia de contraste de fase da biomassa crescida em Q2 com 109 dias: (a) cocos aglomerados; (b) cocos e coco-bacilos suspensos.

Figura 5.10. Coloração de Gram em microscopia de campo claro da biomassa crescida em Q2 com 148 dias: (a) células planctônicas Gram negativas; (b) aglomerado de cocos Gram negativos e bacilos Gram positivos.

Figura 5.11. Variação temporal da concentração de nitrogênio na forma de amônia afluente e efluente em Q1 e Q2..

Figura 5.12. Foto da parte inferior de Q1 mostrando pérolas imobilizadas, grânulos de biomassa e tubo de saída.

Figura 5.13. Variação temporal da concentração de nitrogênio na forma de nitrito e nitrato afluente e efluente em Q1 e Q2.

Figura 5.14. Microscopia de contraste de fase do consórcio enriquecido em Q1 com 312 dias de operação.

Figura 5.15. Microscopia de epifluorescência do consórcio enriquecido em Q1 com 312 dias de operação coradas com DAPI.

Figura 5.16. Microscopia de epifluorescência do consórcio enriquecido em Q1 com 312 dias de 
Figura 5.17. Microscopia de contraste de fase do consórcio enriquecido em Q2 com 312 dias de operação.

Figura 5.18. Microscopia de epifluorescência do consórcio enriquecido em Q2 com 312 dias de operação coradas com DAPI

Figura 5.19. Microscopia de epifluorescência do consórcio enriquecido em Q2 com 312 dias de operação hibridadas com sonda AMX-368 CY3.

Figura 5.20. Fotografia da análise de DGGE de produtos de PCR com primers universais para Domínio Bacteria (968F-1392R) das amostras do Quimiostato Q1. Canaleta $1=$ inóculo, $2=$ 143 dias, $3=197$ dias, $4=197$ dias após purificação (Percoll), 5=262 dias, $6=262$ dias após purificação (Percoll), 7316 dias.

Figura 5.21. Fotografia da análise de DGGE de produtos de PCR com primers universais para Domínio Bacteria (968F-1392R) das amostras do Quimiostato Q2. Canaleta $1=$ inóculo, $2=$ 143 dias, $3=197$ dias, $4=197$ dias após purificação (Percoll), $5=262$ dias, $6=262$ dias após purificação (Percoll), 7316 dias.

Figura 5.22. Fotografia da análise de DGGE de produtos de PCR com primers universais para Domínio Bacteria (968F-1392R) das amostras do Quimiostato Q1, com bandas retiradas para seqüênciamento. Canaleta $1=$ inóculo, $2=143$ dias, $3=197$ dias, $4=197$ dias após purificação (Percoll), $5=262$ dias, $6=262$ dias após purificação (Percoll), 7316 dias.

Figura 5.23. Fotografia da análise de DGGE de produtos de PCR com primers universais para Domínio Bacteria (968F-1392R) das amostras do Quimiostato Q2, com bandas retiradas para seqüênciamento. Canaleta $1=$ inóculo, $2=143$ dias, $3=197$ dias, $4=197$ dias após purificação (Percoll), $5=262$ dias, $6=262$ dias após purificação (Percoll), 7316 dias.

Figura 5.24. Árvore filogenética de máxima verossimilhança do DNA ribossomal 16S, mostrando similaridades entre seqüências obtidas das bandas 7 e 9 e membros do grupo das Bactérias verdes não sulfurosas, filo Planctomyces, Bacterioidetes, Actinobactérias, Firmicutes e Proteobacteria. A barra significa distância filogenética relativa, observada somente horizontalmente, entre dois ramos da árvore. . .48

Figura 5.25. Árvore filogenética de máxima verossimilhança do DNA ribossomal $16 \mathrm{~S}$ das seqüências 7 e 9 em relação ao grupo de bactérias verdes não-sulfurosas (Chloroflexi) mais relacionadas, bactérias anammox, E. coli. Aquifex aeolicus foi utilizado como grupo externo. A barra significa distância filogenética relativa entre dois ramos da árvore.

Figura 5.26. Árvore filogenética de máxima verossimilhança do DNA ribossomal 16S das seqüências 7 e 9 em relação ao grupo de bactérias verdes não-sulfurosas (Chloroflexi). Aquifex aeolicus foi utilizado como grupo externo. A barra significa distância filogenética relativa entre dois ramos da árvore. 


\section{LISTA DE TABELAS}

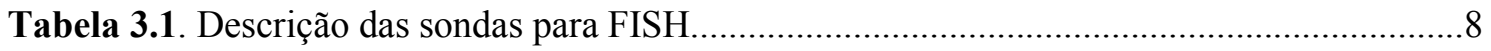

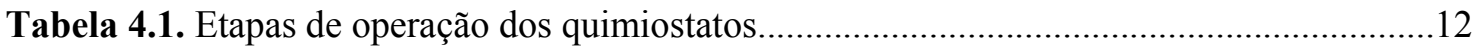

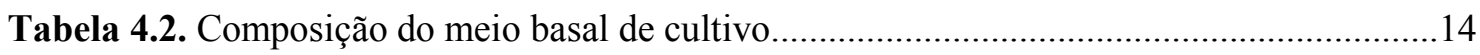

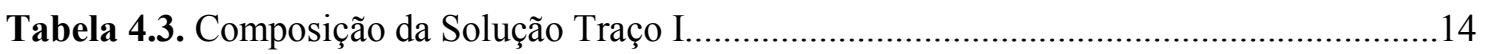

Tabela 4.4. Composição da Solução Traço II.............................................................................14

Tabela 4.5. Protocolo de purificação da cultura anammox..........................................................

Tabela 4.6. Soluções Tampão de hibridação e lavagem utilizadas na técnica FISH....................18

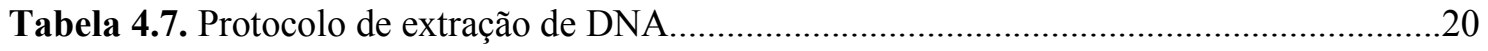

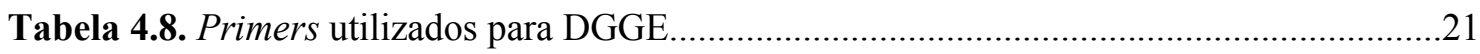

Tabela 5.1. Concentração da biomassa como STV nos quimiostatos..........................................28

Tabela 5.2. Análises dos compostos nitrogenados no frasco de alimentação e na entrada dos

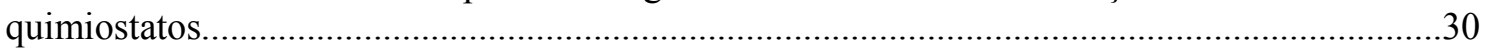

Tabela 5.3. Quantidade removida de nitrogênio na forma dos compostos nitrogenados e proporção de remoção

Tabela 5.4. Parâmetros estequiométricos de amônia e nitrito removidos e nitrato gerado, a partir do $274^{\circ}$ dia de operação.

Tabela 5.5. Comparação entre parâmetros estequiométricos encontrados na literatura e desta pesquisa.

Tabela 5.6. Carga volumétrica de cada composto nitrogenado e total e respectivas remoções médias ( \pm desvio padrão), nos dois períodos de estabilização de Q1

Tabela 5.7. Carga volumétrica de cada composto nitrogenado e total e respectivas remoções médias ( \pm desvio padrão), nos dois períodos de estabilização de Q2. 


\section{LISTA DE ABREVIATURAS E SÍMBOLOS}

ANAMMOX - anaerobic ammonium oxidation (oxidação anaeróbia da amônia)

ASBR - reator anaeróbio seqüencial de batelada

CANON - Completely Autotrophic Nitrogen removal Over Nitrito

$\mathrm{CCCP}$ - cianeto de carbonil $m$-clorofenilhidrazona

DGGE - eletrofose em gel por gradiente desnaturante

DNA - ácido desoxirribonucléico

DNAr - seqüência de DNA que codifica o ribossomo $16 \mathrm{~S}$

DQO - demanda química de oxigênio

EDTA - ácido etinodiaminotetra acético

FIA - análise por injeção em fluxo

FISH - Hibridação in situ com sondas fluorescentes

$\mathrm{N}-\mathrm{NH}_{4}{ }^{+}$- nitrogênio na forma de íon amônio

$\mathrm{N}-\mathrm{NO}_{2}{ }^{-}-$nitrogênio na forma de nitrito

$\mathrm{N}-\mathrm{NO}_{3}{ }^{-}-$nitrogênio na forma de nitrato

$\mathrm{g}$ - unidade de centrifugação (gravidade)

$\mu$ max - velocidade máxima de crescimento

PBS - Phosphate-Buffered Saline (Tampão Fosfato Salino)

PCR - reação em cadeia da polimerase

PVC - poli cloreto de vinila

$\mathrm{pH}$ - potencial hidrogeniônico

Q1- quimiostato 1 (inóculo de reator UASB de abatedouro de aves- Avícola DACAR, Tietê)

Q2 - quimiostato 2 ( inóculo de indústria alimentícia AJINOMOTO-Valparaíso)

RNA - ácido ribonucléico

RSB - reator seqüencial de batelada

SDS - dodecil sulfonato de sódio

SSV - sólidos suspensos voláteis

SHARON Single reactor system for high ammonium removal over nitrite

STV - sólidos totais voláteis

TDH - tempo de detenção hidráulica

UASB reator - reator anaeróbio de fluxo ascendente e manta de lodo

UV - ultravioleta

${ }^{\circ} \mathrm{C}$ - graus Celsius 


\section{SUMÁRIO}

1. INTRODUÇÃO

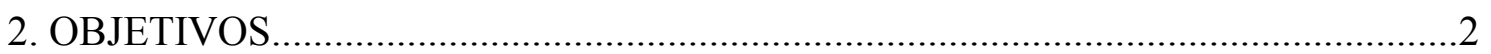

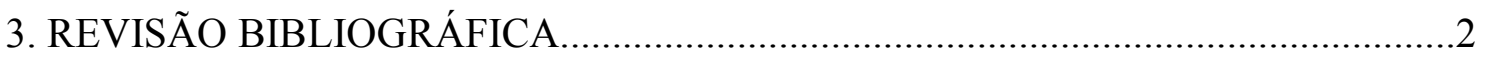

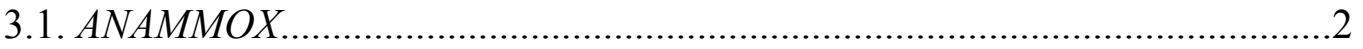

3.2. TECNOLOGIAS NÃO-CONVENCIONAIS PARA REMOÇÃO DE

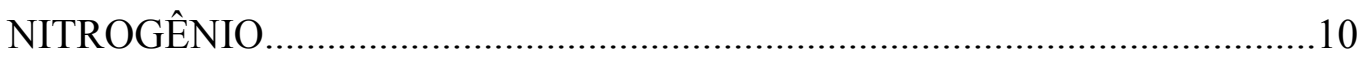

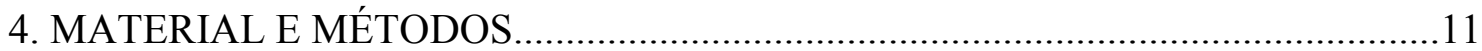

4.1. ORGANOGRAMA EXPERIMENTAL_.....................................................11

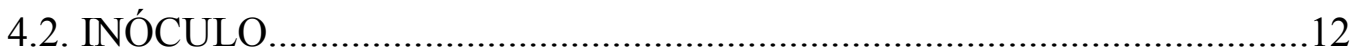

4.3. ENRIQUECIMENTO ......................................................................... 13

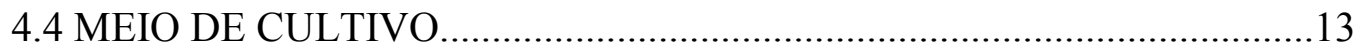

4.5. OPERAÇÃO DOS QUIMIOSTATOS ANAMMOX...................................14

4.6. EXAMES MICROSCÓPICOS......................................................................16

4.7. ANÁLISES FÍSICO-QUÍMICAS.............................................................16

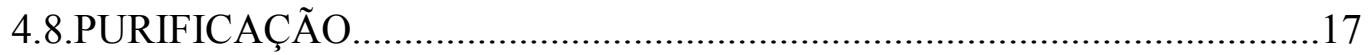

4.9. TÉCNICAS DE BIOLOGIA MOLECULAR .............................................17

4.9.1. Hibridação in situ com Sondas Fluorescentes..........................................17

4.9.2. Análises da Diversidade dos Consórcios Microbianos.............................19

4.9.3. Reação em Cadeia da Polimerase e Eletroforese em Gel de Gradiente

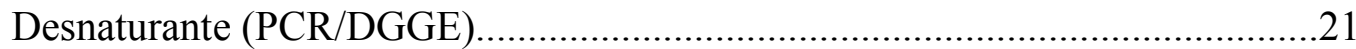

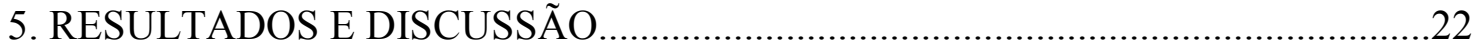

5.1. CARACTERISTICAS GERAIS DOS CONSÓCIOS ENRIQUECIDOS...22

5.2. OPERAÇÃO DOS QUIMIOSTATOS.......................................................28

5.2.1. REMOÇÃO DO NITROGÊNIO AMONIACAL .....................................28

5.2.2. REMOÇÃO DO NITROGÊNIO NA FORMA DE NITRITO E

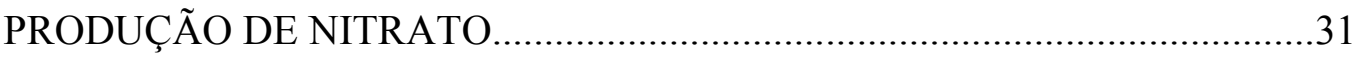

5.3. HIBRIDAÇÃO IN SITU COM SONDAS FLUORESCENTES (FISH).................39

5.4. ANÁLISE DA COMUNIDADE MICROBIANA...................................................42

5.5. SEQÜENCIAMENTO DE BANDA E FILOGENIA.............................................44

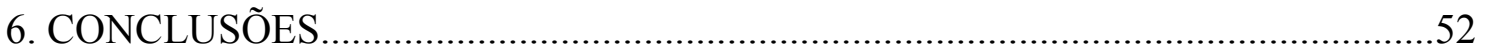

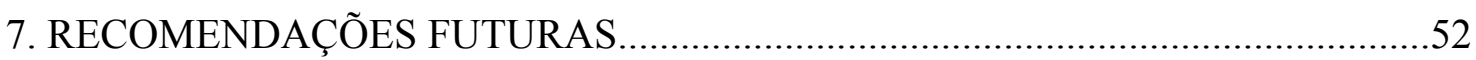

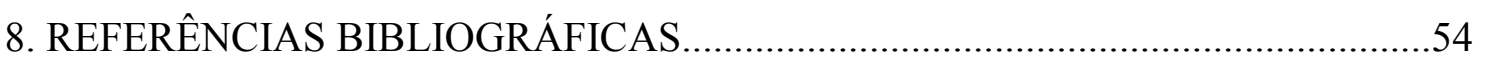




\section{INTRODUÇÃO}

A poluição por compostos nitrogenados, principalmente, o excesso de amônia nos corpos d'água advindo das práticas de fertilização e de lançamentos de águas residuárias, é causa de preocupação. Esse nitrogênio, descarregado na natureza, afeta os ciclos biogeoquímicos por estimular organismos fotossintetizantes, que fixam carbono e aumentam a concentração da biomassa presente nos corpos d'água.

A nitrificação e desnitrificação são processos consolidados na remoção de nitrogênio em estações de tratamento de águas residuárias e esgoto sanitário (Verstraete \& Philips, 1998; Schimidt et al., 2003).

Além da nitrificação clássica, a amônia também pode ser oxidada em ambientes anaeróbios, no processo conhecido como anammox (oxidação anaeróbia da amônia). Esse processo envolve a remoção de nitrogênio, de águas residuárias, sob condições anaeróbias, principalmente aquelas com teores reduzidos de matéria orgânica (Strous et al., 1999a). Do ponto de vista da preservação ambiental, o processo anammox pode ser considerado uma perspectiva para o tratamento de águas residuárias anaeróbias, promovendo a remoção de amônia e aminas (Madigan et al., 2004).

As bactérias capazes de oxidar amônia anaerobiamente eram desconhecidas até a década de 1990, e em 1977, BRODA considerou-as como "litotróficas perdidas na natureza". Segundo o autor, essa rota metabólica era reconhecida por ser termodinamicamente possível, mas os microrganismos quimioautotróficos responsáveis, nunca haviam sido encontrados.

MULDER et al. (1995) descreveram esse processo em reator desnitrificante, em escala piloto, em Gist-brocades, Delft (Holanda). Os autores observaram que a amônia e nitrato eram consumidos com concomitante produção de gás nitrogênio. As evidências da oxidação anaeróbia da amônia foram baseadas nos balanços de nitrogênio; ou seja, 5mols de amônia para cada $3 \mathrm{mols}$ de nitrato, formando $4 \mathrm{mols}$ de nitrogênio gasoso. Experimentos com reatores em batelada, realizados posteriormente, demonstraram que a conversão foi dependente de nitrato.

Devido à configuração básica, o processo anammox é uma opção para o tratamento biológico de águas residuárias (Strous et al., 1997b; Jetten et al., 1999). Thamdrup \& Dalsgaard (2002) relataram que este processo contribui até $67 \%$ na produção de nitrogênio $\left(\mathrm{N}_{2}\right)$ nos oceanos.

Segundo JETTEN et al. (2001a), a aplicação do processo anammox para remoção de 
nitrogênio pode reduzir os custos operacionais em até $90 \%$, focalizando principalmente águas residuárias com elevadas concentrações de nitrogênio e reduzidas concentrações de matéria orgânica como, por exemplo, efluentes de digestores de lodo.

Desse modo, a presente pesquisa visou contribuir para o entendimento do processo anammox através do enriquecimento de consórcios microbianos em quimiostatos; uma vez que a obtenção dessas células é possível após 150 dias de operação em função do tempo de geração elevado (11 a 29 dias).

\section{OBJETIVOS}

- Enriquecer em quimiostatos, separadamente, dois inóculos em condições anammox;

- Purificar as culturas enriquecidas utilizando protocolo Percoll;

- Avaliar a diversidade genética dos consórcios microbianos enriquecidos utilizando a técnica do DGGE,

- Utilizar a técnica de hibridação in situ (FISH) para confirmar a presença de consórcio microbiano anammox,

- Aproximar filogeneticamente a cultura purificada utilizando o seqüenciamento parcial do DNA ribossomal 16S.

\section{REVISÃO BIBLIOGRÁFICA}

\subsection{ANAMMOX (ANaerobic AMMonium OXidation/oxidação anaeróbia da} amônia)

A anammox é o processo biológico em que a oxidação da amônia ocorre concomitantemente à redução do nitrito utilizando carbono inorgânico para crescimento microbiano. Pelo menos três enzimas estão envolvidas diretamente neste processo, a nitrito redutase, hidrazina hidrolase e hidroxilamina oxido-redutase (Figura 3.1).

Esse processo é mediado por bactérias da Ordem Planctomycetales (Strous et al., 1999a). Existem quatro gêneros descritos e sete espécies, tais como: Candidatus "Brocadia anammoxidans", "B. fulgida", Candidatus "Kuenenia stuttgartiensis", Candidatus "Anammoxoglobus propionicus" e Candidatus "Scalindua brodae", "S. wagneri” "S. sorokinii"; sendo esta última encontrada no Mar Negro. 
Estudos filogenéticos utilizando seqüências do RNA ribossomal 16S identificaram esses microrganismos autotróficos como sendo relacionados aos membros da Divisão Planctomycetes (Ordem Planctomycetales) do Domínio Bacteria. Anteriormente, acreditava-se que os planctomicetos eram de limitada relevância ambiental, mas recentes estudos em ecologia microbiana mostraram que essas bactérias são ubíquas (STROUS et al., 1999a).

Segundo FUERST (1995) as bactérias pertencentes à classe Planctomycetales pertencem a um dos mais distintos grupos do domínio Bacteria. Os planctomicetos não possuem peptideoglicano em sua parede celular, na superfície celular são observadas estruturas crateriformes, compartimentalização citoplasmática e reprodução diferente dos demais grupos.

O catabolismo anammox é realizado no compartimento intracitoplasmático limitado por membrana, chamado anamoxossomo (Figura 3.1). Este compartimento tem uma delicada membrana impermeável devido aos lipídeos que a compõe (Sinnighe et al., 2002), e contém pequenas quantidades de DNA ou RNA (Lindsay et al., 2001).

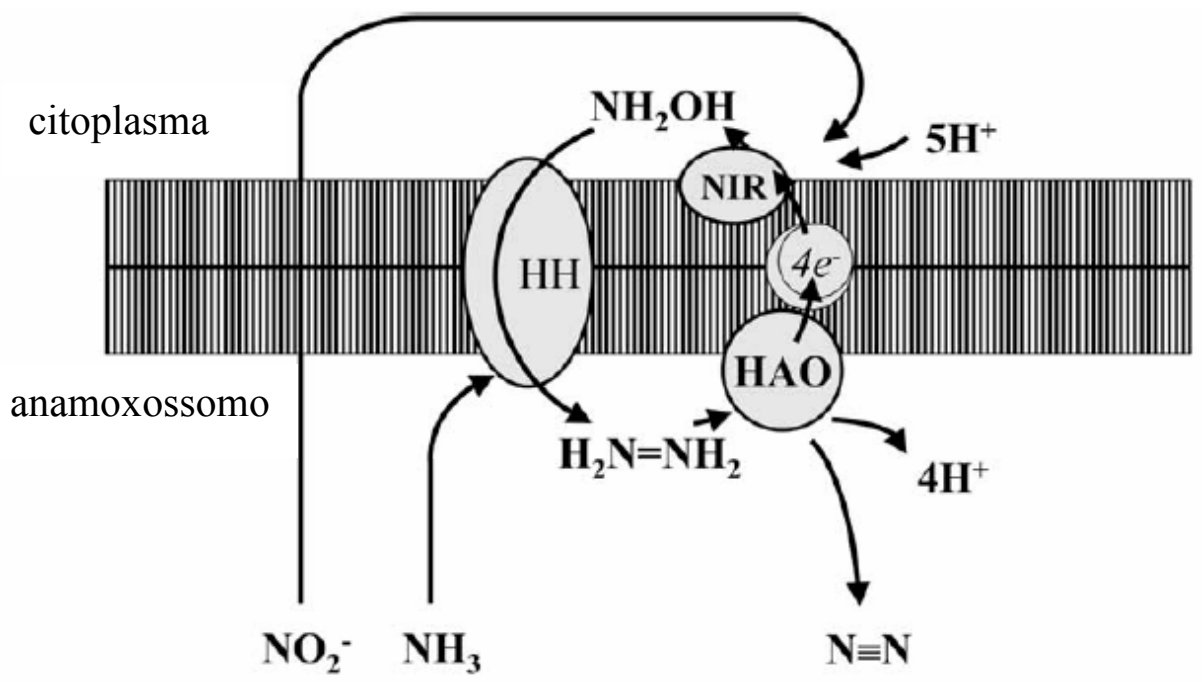

Figura 3.1. Esquema do catabolismo anammox. $\mathrm{NIR}=$ nitrito redutase, $\mathrm{HH}=$ hidrazina hidrolase, $\mathrm{HAO}=$ hidroxilamina oxido-redutase.

Fonte: JETTEN et al. (2002) (adaptado).

SINNINGHE-DAMSTE et al. (2002) estudaram profundamente a membrana presente no anamoxossomo, e observaram que esta é muito menos permeável que as demais biomembranas, sendo constituída por lipídeos em forma de escada, chamados ladderane. Além desta característica, os autores encontraram ligações diéter e éster entre os lipídeos e glicerol desta membrana. A ligação éter é encontrada, principalmente, em microrganismos pertencentes ao Domínio Archaea, no entanto bactérias termófilas de ramificação antiga 
como Thermotoga e Aquifex têm ligações éster e éter, assim como, dois gêneros de bactérias redutoras de sulfato mesofílicas Desulfosarcina variabilis e Desulforhabdus amnigenus.

MULDER et al. (1995) observaram consumo de amônia, em reator desnitrificante de leito fluidificado, aplicado ao tratamento do efluente de reator metanogênico de fábrica de produção de fermento, em Delft (Holanda), após 420 dias de operação, à taxa de remoção de $0,4 \mathrm{KgN} / \mathrm{m}^{3} / \mathrm{dia}$. A possibilidade da ocorrência da nitrificação aeróbia foi descartada, porque, seria necessária concentração de $1,8 \mathrm{KgO}_{2} / \mathrm{m}^{3} /$ dia, para ocorrência desse processo. Além disso, não foi encontrado oxigênio molecular nas amostras.

VAN DE GRAAF et al. (1995) provaram que o processo anammox é biológico. Os autores realizaram experimentos em batelada, sob condições anaeróbias. Os reatores controle foram preparados com água residuária, sem inóculo (lodo utilizado por MULDER et al., 1995) ou com lodo esterilizado em autoclave ou por radiação gama. Nos reatores alimentados com cloranfenicol, ampicilina, 2,4 diclorofenol, cianeto de carbonil $\mathrm{m}$ clorofenilhidrazona (CCCP) e cloreto de mercúrio o processo foi completamente inibido. Nos reatores com inóculo, $110 \mathrm{mg} / \mathrm{L}$ de amônia foram oxidadas em 9 dias. Os autores verificaram, também, que a remoção da amônia foi proporcional à quantidade de inóculo inicial e não relacionada à concentração de substrato.

VAN DE GRAAF et al. (1997) observaram a produção exclusiva de ${ }^{14-15} \mathrm{~N}_{2}$ em experimentos com amônia $\left({ }^{15} \mathrm{NH}_{4}^{+}\right)$e nitrato $\left({ }^{14} \mathrm{NO}_{3}{ }^{-}\right)$em reatores de batelada. Esses resultados não estão em acordo com a reação postulada por MULDER et al. (1995), como descrito na (Equação 1). Ou seja, cada $\mathrm{N}$-amoniacal requer $0,6 \mathrm{~N}$-nitrato produzindo $0,8 \mathrm{~N}_{2}$, portanto, $75 \%$ do gás deveria estar na forma ${ }^{14-15} \mathrm{~N}_{2}$ e $25 \%{ }^{15-15} \mathrm{~N}_{2}$. No entanto, se o nitrito fosse o aceptor de elétrons, no lugar do nitrato, os resultados observados e calculados estariam em acordo com a Equação 2.

A anammox envolve a oxidação da amônia, utilizando o nitrito como aceptor de elétrons, para produzir nitrogênio gasoso (Equação 2). A nitrificação aeróbia ocorre segundo as Equações 3 ou 4. Tais equações demonstram que o processo anaeróbio é energeticamente mais favorável (Jetten et al., 1999a).

$$
\begin{array}{lll}
5 \mathrm{NH}_{4}{ }^{+}+3 \mathrm{NO}_{3}{ }^{-} \longrightarrow & 4 \mathrm{~N}_{2}+9 \mathrm{H}_{2} \mathrm{O}+2 \mathrm{H}^{+} & \Delta \mathrm{G}^{\circ}=-297 \mathrm{~kJ} \\
\mathrm{NH}_{4}{ }^{+}+\mathrm{NO}_{2}{ }^{-} \longrightarrow & \mathrm{N}_{2}+2 \mathrm{H}_{2} \mathrm{O} & \Delta \mathrm{G}^{\circ}=-357 \mathrm{~kJ} \\
\mathrm{NH}_{4}^{+}+1,5 \mathrm{O}_{2} \longrightarrow & \mathrm{NO}_{2}^{-}+2 \mathrm{H}^{+}+\mathrm{H}_{2} \mathrm{O} & \Delta \mathrm{G}^{\circ}=-275 \mathrm{~kJ} \\
\mathrm{NH}_{4}^{+}+2 \mathrm{O}_{2} \longrightarrow & \mathrm{NO}_{3}{ }^{-}+2 \mathrm{H}^{+}+\mathrm{H}_{2} \mathrm{O} & \Delta \mathrm{G}^{\circ}=-349 \mathrm{~kJ}
\end{array}
$$

Em experimentos em batelada, com Brocadia anammoxidans foi verificada inibição 
irreversível, quando nitrito e fosfato, em concentrações acima de $98 \mathrm{mg} / \mathrm{L}$ e $60 \mathrm{mg} / \mathrm{L}$, respectivamente foram adicionados separadamente nos sistemas (Van de Graaf et al., 1996; Strous et al., 1997a; Strous et al., 1997b). Outra cultura, Kuenenia stuttgartienses tolerou até $180 \mathrm{mg} / \mathrm{L}$ de nitrito e $600 \mathrm{mg} / \mathrm{L}$ de fosfato (Egli et al., 2001) As duas espécies cresceram adequadamente a $37^{\circ} \mathrm{C}$ e $\mathrm{pH} 8$.

A influência do oxigênio no processo anammox foi investigada por STROUS et al. (1997a) em reator de batelada. O reator, alimentado com $84 m g N-\mathrm{NH}_{4}{ }^{+} / \mathrm{L}$ e $112 \mathrm{mgN}-\mathrm{NO}_{2}{ }^{-}$ $/ \mathrm{L}$, foi monitorado durante 20 dias, com ciclos de $2 \mathrm{~h}$ alternados com aeração $\left(\mathrm{O}_{2}\right)$ e anaerobiose (argônio). O processo anammox foi observado somente nos períodos anaeróbios. No período aeróbio não foi observado decréscimo da amônia por nitrificação. Nesse reator em batelada não foi verificada a ocorrência da anammox sob microaerofilia, para tensões de oxigênio iguais a 2, 1, 0,5\%. Porém, o processo foi restabelecido sob anaerobiose, demonstrando que a inibição foi reversível.

A fisiologia de cultura anammox foi estudada por STROUS et al. (1999b) em reatores em batelada. A taxa máxima de consumo de amônia foi de $1,1 \mathrm{~g} \mathrm{~N}-\mathrm{NH}_{4}{ }^{+} / \mathrm{g}$ proteína/dia. Concentrações de até $1 \mathrm{gN} / \mathrm{L}$ na forma de amônia ou nitrato não inibiram a anammox. No entanto, valores acima de $100 \mathrm{mgN} / \mathrm{L}$ de nitrito (por vários dias) inibiram o processo. Todavia, a adição de $1,4 \mathrm{mgN} / \mathrm{L}$ de hidrazina e $0,7 \mathrm{mg}-\mathrm{N} / \mathrm{L}$ de hidroxilamina (intermediários da anammox) restabeleceram o metabolismo.

STROUS et al., (1998) observaram 90\% de retenção da biomassa em reator anaeróbio em batelada seqüencial (ASBR). Essa retenção foi importante para o processo anammox devido ao longo tempo de geração celular. Os autores verificaram, também, outras características favoráveis ao processo e relacionadas com os seguintes aspectos: (1) distribuição homogênea dos substratos, (2) operação segura por mais de um ano, (3) estabilidade sob condições limitantes de substrato.

Baseado no balanço de massa de nitrogênio e carbono, experimentos com culturas anammox enriquecidas indicaram a reação estequiométrica descrita na Equação 5 (Strous et al., 1998). Todavia, a proporção de nitrito e amônia não foi exatamente 1:1, considerando que parte do nitrito oxida a nitrato na rota de redução do $\mathrm{CO}_{2}$ (Van de Graaf et al., 1996).

$$
\begin{aligned}
1 \mathrm{NH}_{4}^{+}+1,32 \mathrm{NO}_{2}^{-}+0,066 \mathrm{HCO}_{3}{ }^{-}+0,13 \mathrm{H}^{+} & \longrightarrow \\
& \longrightarrow 1,02 \mathrm{~N}_{2}+0,26 \mathrm{NO}_{3}{ }^{-}+0,066 \mathrm{CH}_{2} \mathrm{O}_{0,5} \mathrm{~N}_{0,15}+2,03 \mathrm{H}_{2} \mathrm{O}
\end{aligned}
$$

JETTEN et al. (1999), utilizaram como inóculo biomassa do reator desnitrificante 
em escala piloto e obtiveram culturas enriquecidas em 4 meses. Essa cultura enriquecida foi inoculada em reator de leito fluidificado alimentado com meio sintético contendo amônia (70-420mgN-NH$\left.{ }_{4}^{+} / \mathrm{L}\right)$, nitrito (70-490mg N-NO$\left.{ }_{2}^{-} / \mathrm{L}\right)$, bicarbonato de sódio $(1,25 \mathrm{~g} / \mathrm{L})$ e elementos traços. Durante 27 meses foram monitoradas as concentrações de amônia, nitrito e as respectivas remoções foram de $84,6 \%$ e 99,5\%. Sob tais condições, a velocidade máxima de crescimento $(\mu)$ e tempo de geração $(\mathrm{Tg})$ foram de $0,001 \mathrm{~h}^{-1}$ e 29 dias, respectivamente.

JONES et al. (2000) destacaram que a oxidação anaeróbia da amônia pode ser de importância significativa em lagoas anaeróbias devido, principalmente, ao longo tempo de armazenamento comum em tais sistemas. Essa característica é importante na formação de agregados celulares e, por conseguinte poderá favorecer a liberação de nitrogênio molecular renovando o ciclo do nitrogênio.

THAMDRUP \& DALSGAARD (2002) observaram oxidação anaeróbia da amônia associada à redução do nitrato em três amostras de sedimento marinho provenientes do Norte do Mar Báltico e obtidas a 16, 380 e 695m de profundidade, em temperaturas de 6,5; 6 e $5,5{ }^{\circ} \mathrm{C}$, respectivamente. A anammox correspondeu a 2,24 e $67 \%$ da produção de $\mathrm{N}_{2}$, respectivamente nessas amostras ambientais. Todavia, a desnitrificação foi o processo mais importante para amostras de sedimento coletadas a $16 \mathrm{~m}$ de profundidade. Essas observações indicaram que a anammox pode ocorrer, também, em baixas temperaturas.

Após três meses de operação de reator granular de leito expandido, inoculado com lodo de estação de tratamento de água residuária de cervejaria, JAINLONG \& JING (2005) observaram $98 \%$ de remoção de $250 \mathrm{mg} \mathrm{N}^{-N_{2}}{ }_{2} / \mathrm{L}$ e $40 \%$ de remoção de $250 \mathrm{mgN}-\mathrm{NH}_{4}{ }^{+} / \mathrm{L}$ nesse reator. No entanto, essa desproporcionalidade entre nitrito e amônia, em relação ao processo anammox, ocorreu em função da carga orgânica (dextrose) afluente; ou seja, 500mg DQO/L. Desse modo, os autores destacaram que o processo anammox pode ocorrer em reatores que recebem água residuária com matéria orgânica.

EGLI et al. (2001) obtiveram 88\% de bactérias anammox (quantificação por FISH) por método de enriquecimento em reator com biodisco rotativo usado no tratamento de chorume contendo elevadas concentrações de amônia e teores reduzidos de carbono orgânico. A cultura purificada apresentou tolerância de até $600 \mathrm{mg} / \mathrm{L}$ de fosfato e $182 \mathrm{mgN}$ $\mathrm{NO}_{2}{ }^{-} / \mathrm{L}$; ou seja, valores maiores que os observados para Brocadia anammoxidans. Todavia, a atividade catalítica anammox foi até 20 vezes menor que B. anammoxidans. Análises do seqüenciamento do DNA ribossomal 16S revelaram que a cultura apresentou 90,9\% de similaridade com B. anammoxidans e 98,5\% com Kuenenia stuttgatiensis. 
TOH et al. (2002) enriqueceram consórcio microbiano, capaz de oxidar anaerobiamente, a amônia a partir de lodo de estação de tratamento de esgoto municipal (Sydney-Austrália). Para iniciar o enriquecimento, os autores adicionaram 100mg/L de cloramfenicol para inibir a microbiota desnitrificante, uma vez que os microrganismos anammox não são suscetíveis a esse antibiótico. O consórcio apresentou $50 \%$ de bactérias anammox (FISH) e afinidade com $B$. anammoxidans, utilizando-se sonda específica para este microrganismo. Além disso, foi capaz de remover até $60 \mathrm{mg} \mathrm{N} / \mathrm{dia}$ em reator de fluxo contínuo operado com vazão de $25 \mathrm{~mL} / \mathrm{h}$, após 243 dias de operação.

KUYPERS et al. (2003) observaram pela primeira vez, em amostras do Mar Negro, células anammox planctônicas. Segundo os autores a presença de tais células pode ser de importante relevância na regeneração do $\mathrm{N}_{2}$ a partir do nitrogênio fixo em zonas anóxicas. Para comprovar o processo anammox no Mar Negro os pesquisadores retiraram amostras da coluna d'água de várias profundidades e incubaram com nitrito $\left({ }^{14} \mathrm{~N}\right)$ e amônia $\left({ }^{15} \mathrm{~N}\right)$ e encontraram $\mathrm{N}_{2}\left({ }^{14} \mathrm{~N}^{15} \mathrm{~N}\right)$ no biogás. Os autores, também, extraíram e analisaram a composição dos lipídeos ladderane, encontrando três tipos, somente nas amostras de onde ocorreu a maior porcentagem de ${ }^{14} \mathrm{~N}^{15} \mathrm{~N}$ no biogás. Análises filogenéticas do DNA ribossomal $16 \mathrm{~S}$ indicaram que se tratava de novo gênero nomeado Candidatus "Scalindua sorokinii". Nova sonda de FISH (S-*-BS-820-a-A-22) foi desenhada para esses organismos que apresentaram a incomum organela com lipídeos ladderane (Tabela 3.1).

Ainda em 2003, SCHMID et al. encontraram mais duas espécies do gênero Scalindua, Candidatus "S. brodae" e "S. wagneri" no biofilme do reator nitrificante com biodiscos rotativos, sob condições limitantes de oxigênio utilizado no tratamento de chorume, situado na cidade de Pitsea (Reino Unido). O biofilme tinha elevada atividade anammox, ou seja, $5 \mathrm{nmol} / \mathrm{mg}$ proteína.min, correspondendo a $25 \%$ da atividade relatada para reatores enriquecidos com $80 \%$ de células anammox, sob condições similares. No entanto, a sonda descrita por SCHMID et al. (2000) (S-*-Amx-0820-a-A-22) não detectou a presença de $K$. stuttgartiensis ou B. anammoxidans. Todavia, a sonda S-P-Planc-0046-a-A18 (Neef el al., 1998) revelou que 20\% da comunidade microbiana total pertencia à ordem Planctomycelales. Os autores então desenharam três novas sondas: S-G-Sca-1309-a-A-21 para o Scalindua, S-*-Scabr-1114-a-A-22 para S. brodae e uma sonda para todos os microrganismos anammox (S-*-Amx-0368-a-A-18) (Tabela 3.1). 
Tabela 3.1 Descrição das sondas para FISH

\begin{tabular}{|c|c|c|c|}
\hline Sonda & Seqüência $5^{\prime} \rightarrow 3^{\prime}$ & Especificidade & Referência \\
\hline S-P-Planc-0046-a-A-18 & GACTTGCATGCCTAATCC & $\begin{array}{l}\text { Orden } \\
\text { Plactomycetales }\end{array}$ & $\begin{array}{l}\text { Neef et al. } \\
1998\end{array}$ \\
\hline S-*-Amx-0820-a-A-22 & AAAACCCCTCTACTTAGTGCCC & $\begin{array}{l}\text { Cand. "Brocadia } \\
\text { anammoxidans" } \\
\text { "Kuenenia } \\
\text { stuttgartiensis" }\end{array}$ & $\begin{array}{l}\text { Schmid et al. } \\
2000\end{array}$ \\
\hline S-*-Kst-1225-a-A-20 & TCGGCTTTATAGGTTTCGCA & $\begin{array}{l}\text { Candidatus } \\
\text { "Kuenenia } \\
\text { stuttgartiensis" }\end{array}$ & $\begin{array}{l}\text { Schmid et al. } \\
2000\end{array}$ \\
\hline S-G-Sca-1309-a-A-21 & TGGAGGCGAATTTCAGCCTCC & Gênero "Scalindua" & $\begin{array}{l}\text { Schmid et al. } \\
2003\end{array}$ \\
\hline S-*-Scabr-1114-a-A-2 & CCCGCTGGTAACTAAAAACAAG & Cand. "S. brodae" & $\begin{array}{l}\text { Schmid et al. } \\
2003\end{array}$ \\
\hline S-*-Amx-0368-a-A-18 & CCTTTCGGGCATTGCGAA & $\begin{array}{l}\text { Todos organismos } \\
\text { anammox }\end{array}$ & $\begin{array}{l}\text { Schmid et al. } \\
2003\end{array}$ \\
\hline S-*-BS-820-a-A-22 & TAATTCCCTCTACTTAGTGCCC & $\begin{array}{l}\text { Cand. "Scalidua } \\
\text { wagneri" } \\
\text { "S. sorokinii" }\end{array}$ & $\begin{array}{l}\text { Kuypers et } \\
\text { al. } 2003\end{array}$ \\
\hline
\end{tabular}

Em escala de bancada, experimentos mostraram que reatores anammox são extremamente compactos e apresentam altas taxas de remoção $\left(15 \mathrm{~kg} \mathrm{~N} / \mathrm{m}^{3} /\right.$ dia $)$. Devido à baixa velocidade de crescimento das bactérias anammox, o tempo de partida dos reatores é muito longo; ou seja, de 100 a 150 dias. Portanto, a retenção do lodo é extremamente importante neste processo (Schmidt et al., 2003).

DAPENA-MORA et al. (2004) utilizaram as seguintes configurações de reatores para avaliação do processo anammox: gas-lift e reator seqüencial de batelada (RSB). O reator gas-lift foi inoculado com 0,36g SSV/L de lodo utilizado por STROUS et al. (1998). Após 200 dias de operação do reator gas-lift a carga aplicada de remoção de nitrogênio (nitrito e amônia) elevou de 0,42 a 2,0gN/L.dia para atividade anammox de $1,15 \mathrm{gN} / \mathrm{gSSV}$.dia. A biomassa neste reator aumentou em 2,3gSSV/L. O RSB foi inoculado com 1,5g SSV/L de biomassa do reator gas-lift. Após 150 dias, ocorreu crescimento de biomassa atingindo valor de $2,5 \mathrm{gSSV} / \mathrm{L}$ e a carga aplicada de remoção de nitrogênio elevou de 0,1 para 0,7gN/L.dia. Todavia, a atividade anammox da biomassa desse reator 
$(0,65 \mathrm{gN} / \mathrm{gSSV}$.dia $)$ foi menor do que aquela observada para o reator gas-lift $(1,15 \mathrm{gN} / \mathrm{gSSV} . \mathrm{dia})$.

KIELING et al. (2005) avaliaram a lavagem do lodo como estratégia para redução do tempo de partida de reatores anammox. Foi utilizado lodo de estação de tratamento de esgotos domésticos de Florianópolis para comparação de duas estratégias iniciais: enriquecimento em reator anaeróbio seqüencial de batelada (ASBR) operado como reator de mistura completa com taxa de diluição de $0,2 \mathrm{~d}^{-1}$ promovendo a lavagem de parte do lodo (RI) e com retenção celular total em RII (ASBR). As taxas de remoção de nitrogênio na última fase do experimento (310 a 380 dias) em RI e RII foram de $52 \%$ e $28 \%$ e carga nitrogenada total removida de $85 \mathrm{mg}-\mathrm{N} / \mathrm{gSST}$.d e $6,08 \mathrm{mg}-\mathrm{N} / \mathrm{gSST} . \mathrm{d}$, respectivamente. Esses resultados, segundo os autores, indicaram que a retenção celular (como SST) não foi efetiva para remoção de nitrogênio. Ainda, neste estudo, utilizando a técnica de hibridização in situ (FISH) foram observados microrganismos anammox, somente, em RI após 225 dias de operação. No entanto, o processo anammox se estabeleceu, provavelmente, após 130 dias da partida do reator, segundo análises de remoção de nitrito e amônio.

REGINATTO et al. (2005) observaram em reator desnitrificante, operado com reator nitrificante para o tratamento de água residuária de suinocultura, a remoção de $50 \mathrm{mgN}-\mathrm{NH}_{4}{ }^{+} /$L.dia. A biomassa do reator desnitrificante foi utilizada com inóculo para operação de reator em batelada alimentado com meio específico para anammox. Nessa última condição a eficiência máxima de remoção foi de $95 \%$ para carga volumétrica de nitrogênio total de $33 \mathrm{mg} \mathrm{N}_{\text {total }} / \mathrm{L}$.dia.

KARTAL et al. (2007) descreveram nova espécie de bactéria anammox, presente em reator em batelada seqüencial, com metabolismo diferente das anteriormente descritas. Essa nova espécie foi capaz de co-oxidar amônio e ácido propiônico, e provisoriamente denominada Candidatus "Anammoxoglobus propionicus". Essa espécie apresentou velocidade específica de remoção de ácido propiônico de $0,64 \mu \mathrm{mol} / \mathrm{g}$ proteína.min. Os autores realizaram experimento em batelada inoculado com $60 \%$ da cultura purificada de Candidatus "B. anammoxidans" e $40 \%$ da cultura enriquecida de Candidatus “Anammoxoglobus propionicus", em meio com nitrito (1260mgN-NO $\left.{ }_{2}{ }^{\circ} / \mathrm{dia}\right)$, amônia (1260mgN-NH${ }_{4}^{+} /$dia) e 1,095mg propionato/dia. Após 4 meses de operação a população da espécie heterotrófica (Candidatus "Anammoxoglobus propionicus") apresentou 99\% do total de células detectadas por análises de FISH.

Este trabalho enriqueceu consórcios microbianos em quimiostatos utilizando-se dois inóculos diferentes. Técnicas tradicionais de microbiologia foram usadas para caracterizar 
morfologicamente as células presentes nos dois quimiostatos. Técnicas de biologia molecular como FISH (Hibridação in situ com Sondas Fluorescentes) e reação em cadeia da polimerase e Eletroforese em Gel de Gradiente Desnaturante (PCR/DGGE), forneceram informações sobre a diversidade de microrganismos e análises filogenéticas. As cargas nitrogenadas aplicadas nos dois quimiostatos foram menores em relação a muitos trabalhos apresentados anteriormente, no entanto foram alcançadas remoções satisfatórias em ambos quimiostatos.

\subsection{TECNOLOGIAS NÃO-CONVENCIONAIS PARA REMOÇÃO DE} NITROGÊNIO

Em ecossistemas naturais e antrópicos microrganismos nitrificantes amôniooxidantes podem cooperar com bactérias anammox protegendo-as do oxigênio e provendo nitrito para oxidação anaeróbia da amônia. Essa é a base eco-fisiológica para aplicação tecnológica em dois processos: SHARON e CANON.

O processo Sharon ("Single reactor system for high ammonium removal over nitrite") é técnica empregada para tratamento biológico de efluentes com elevadas cargas de nitrogênio. Neste processo, o amônio é parcialmente convertido a nitrito sob condições aeróbias por bactérias amônio-oxidantes (Nitrosomonas $\mathrm{sp}$.), de acordo com a reação (3).

$$
\mathrm{NH}_{4}{ }^{+}+1,5 \mathrm{O}_{2} \longrightarrow \mathrm{NO}_{2}^{-}+2 \mathrm{H}^{+}+\mathrm{H}_{2} \mathrm{O} \quad \Delta \mathrm{G}^{\circ}=-275 \mathrm{~kJ}
$$

O processo Sharon está baseado em dois princípios: tempo de detenção hidráulica (TDH) de aproximadamente 1 dia e temperatura elevada (acima de $30^{\circ} \mathrm{C}$ ). Nessas condições bactérias nitrito-oxidantes; tais como, Nitrobacter sp. e Nitrospira sp. são lavadas do reator. Por outro lado, o crescimento das bactérias amônio-oxidantes é favorecido.

A elevada temperatura e reduzido TDH atuam selecionando microrganismos amônio-oxidantes, uma vez que, a $35^{\circ} \mathrm{C}$ a velocidade máxima de crescimento ( $\mu$ max) das bactérias nitrito-oxidantes $\left(0,5 \mathrm{~d}^{-1}\right)$ é aproximadamente a metade daquela observada para as bactérias amônio-oxidantes $\left(1 \mathrm{~d}^{-1}\right)$ (VERSTRAETE \& PHILIPS, 1998; JETTEN et al., 2001b).

JETTEN et al. (2001b) estudaram a combinação dos processos SHARON e anammox para a remoção de nitrogênio. O reator utilizado para o processo SHARON foi alimentado com efluente de digestão de lodo com elevada concentração de amônio $\left(1180 \mathrm{mgN}-\mathrm{NH}_{4}{ }^{+} / \mathrm{L}\right)$, operado a $35^{\circ} \mathrm{C}$ e $\mathrm{TDH}$ de 1 , após alcançada estabilidade (20 dias) o 
processo foi estável por mais de dois anos. O processo anammox foi realizado no reator seqüencial de batelada (RSB) que recebeu como inóculo lodo enriquecido, previamente, sob condições anammox. O RSB foi alimentado com efluente do reator SHARON contendo $550 \mathrm{mgN}-\mathrm{NH}_{4}{ }^{+} / \mathrm{L}$ e $600 \mathrm{mgN}-\mathrm{NO}_{2}{ }^{-} /$dia. O processo anammox foi estabelecido sendo detectado mais de $80 \%$ de $\mathrm{N}_{2}$ no headspace. Tais resultados indicaram que o processo Sharon-anammox pode ser utilizado para remoção de nitrogênio amoniacal com estabilidade.

No processo CANON ("Completely Autotrophic Nitrogen removal Over Nitrito”), amônio é parcialmente convertido a nitrito por bactérias amônio-oxidantes aeróbias sob condições limitantes de oxigênio e, em zonas anaeróbias (eg. interior do floco), bactérias anammox convertem nitrito produzido e amônio restante a nitrogênio gasoso com formação de nitrato, de acordo com as reações seqüenciais 3 e 5. Para que ocorra o processo CANON é necessária a remoção total do oxigênio por bactérias amônio-oxidantes, uma vez que as células anammox são inibidas reversivelmente por baixos teores de oxigênio $(0,5 \%$ da saturação).

\section{MATERIAL E MÉTODOS}

\subsection{ORGANOGRAMA EXPERIMENTAL}

Dois inóculos foram enriquecidos, sob condições anammox, em quimiostatos com concentrações iniciais médias de $67,5 \mathrm{mg} \mathrm{N}-\mathrm{NH}_{4}{ }^{+} / 1$ e $75,8 \mathrm{mg} \mathrm{N}-\mathrm{NO}_{2}{ }^{-} / 1$. Foram realizadas análises constantes de monitoramento conforme mostra a Figura 4.1. Amostras da biomassa dos quimiostatos, com 143 dias e 312 dias de operação, foram coletadas para confirmação da presença de microrganismos anammox utilizando a técnica FISH. Foi avaliada a diversidade microbiana por DGGE antes e após a purificação (separação por gradiente de densidade Percoll), e algumas bandas foram selecionadas para identificação por seqüenciamento de fragmentos do DNA ribossomal 16S. A operação dos quimiostatos foi separada, experimentalmente definida, em cinco etapas conforme descrição apresentada na Tabela 4.1. 
Tabela 4.1. Etapas de operação dos quimiostatos.

\begin{tabular}{|c|c|c|}
\hline Etapa & $\begin{array}{c}\text { Período } \\
\text { (dias) }\end{array}$ & Condição \\
\hline $\mathrm{I}$ & $1-136$ & $\begin{array}{l}\text { Afluente variável (dificuldade de } \\
\text { determinação) }\end{array}$ \\
\hline II & $137-218$ & Primeiro período de estabilidade \\
\hline III & $219-232$ & Somente amônia afluente \\
\hline IV & $233-273$ & $\begin{array}{l}\text { Instabilidade devido à nitrificação nas } \\
\text { mangueiras }\end{array}$ \\
\hline $\mathrm{V}$ & $274-296$ & Segundo período de estabilidade \\
\hline
\end{tabular}

Inóculo

Lodo granular de reator UASB de abatedouro de aves (avícola DAKAR-Tietê/SP)
Biomassa de reator nitrificante-desnitrificante de estação de tratamento de água residuária de indústria alimentícia (Ajinomoto-Valparaíso/SP)

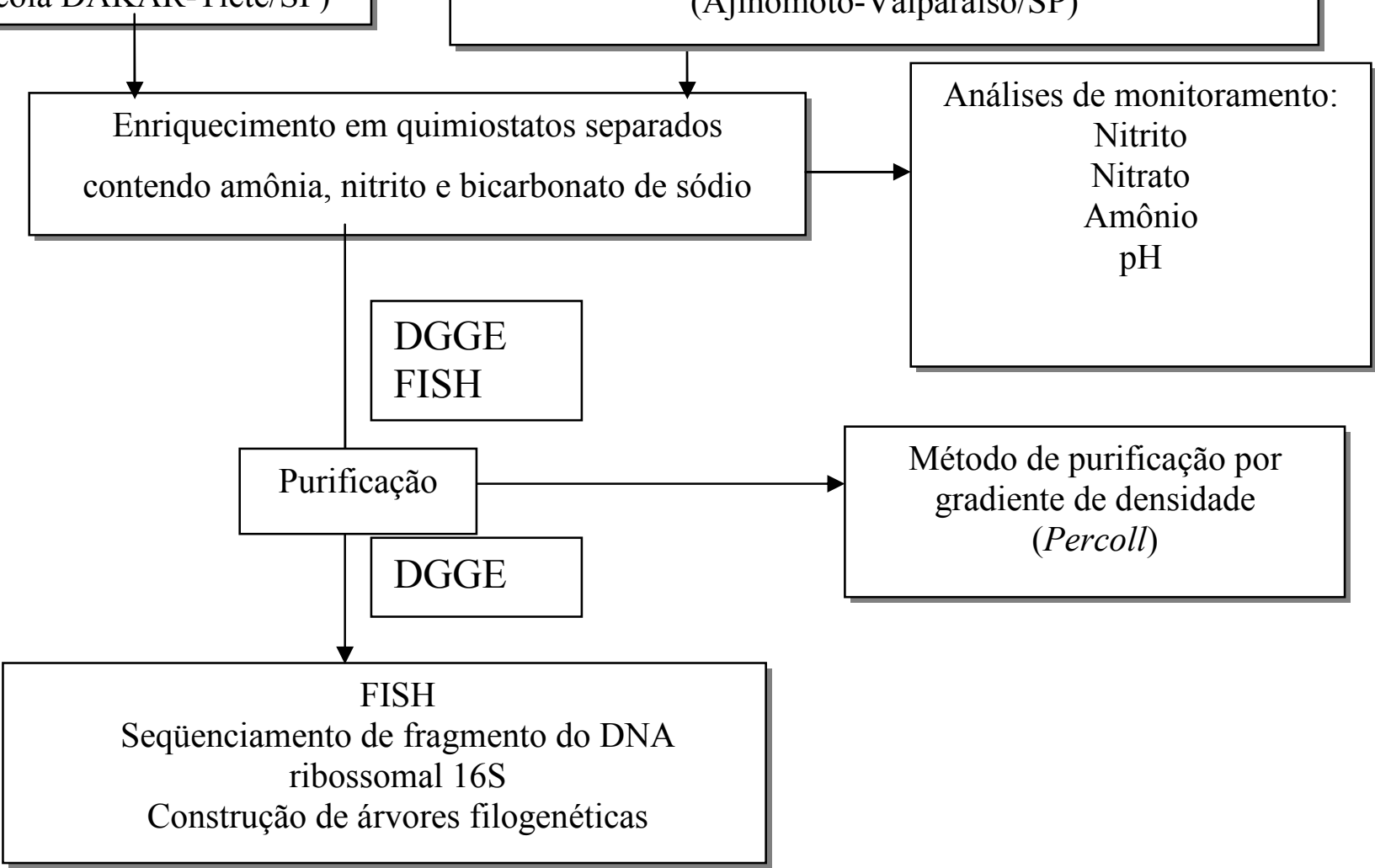

Figura 4.1. Organograma das etapas experimentais.

\subsection{INÓCULO}

$\mathrm{Na}$ preparação dos ensaios de enriquecimento nos quimiostatos anammox foram utilizados, separadamente, os seguintes inóculos: (Q1) 140 gramas de lodo granular úmido 
(concentração do lodo igual a $68,52 \mathrm{mg} \mathrm{STV} / \mathrm{g}$ lodo úmido) proveniente de reator UASB usado no tratamento de água residuária de abatedouro de aves (avícola DACAR-Tietê/SP) e (Q2) 140 gramas de biomassa úmida (concentração da biomassa igual a 22,74mg STV/g biomassa úmida) proveniente de reator nitrificante-desnitrificante, em escala de bancada, de indústria alimentícia (Ajinomoto-Valparaíso/SP).

\subsection{ENRIQUECIMENTO}

O enriquecimento é etapa fundamental no processo de adaptação dos inóculos à nova condição. Essa adaptação foi feita submetendo-se os inóculos a meio basal descrito por VAN DE GRAAF et al. (1996), contendo $5 \mathrm{mM}$ de amônia (70mg $\left.\mathrm{N}^{-\mathrm{NH}_{4}}{ }^{+} / 1\right), 5 \mathrm{mM}$ de nitrito $\left(70 \mathrm{mg} \mathrm{N}-\mathrm{NO}_{2}{ }^{-} / 1\right), 1000 \mathrm{mg} / 1$ de bicarbonato de potássio, minerais e elementos traços. As concentrações de fosfato utilizadas na alimentação dos quimiostatos foram menores que 0,5mM. Os quimiostatos foram submetidos à atmosfera de Argônio (100\%) para garantir condições anaeróbias. Todos os experimentos foram realizados sob temperatura de $37 \pm 1^{\circ} \mathrm{C}$.

\subsection{MEIO DE CULTIVO}

O meio de cultivo adotado foi descrito por VAN DE GRAAF et al., (1996) (Tabela 4.2). Ao meio basal foi adicionada solução de elementos traços (I e II) (Tabelas 4.3 e 4.4) como descrita pelos autores op cit. $\mathrm{O}$ selenito de sódio decahidratado $\left(\mathrm{Na}_{2} \mathrm{SeO}_{4} \cdot 10 \mathrm{H}_{2} \mathrm{O}\right)$ da solução original foi substituído por selenito de sódio $\left(\mathrm{Na}_{2} \mathrm{SeO}_{3}\right)$, mantendo-se a quantidade de selênio adicionada ao meio. O frasco de alimentação contendo o meio de cultura foi autoclavado durante 20 minutos, a $121^{\circ} \mathrm{C}$ e $1 \mathrm{~atm}$. Posteriormente, o frasco contendo o meio de cultura foi submetido à atmosfera de Argônio (100\%), durante 20 minutos, sob condições de assepsia. Nesta fase, sob condições de assepsia foi adicionada a solução de cloreto de cálcio e sulfato de magnésio, previamente, esterilizados separadamente. Em todos os ensaios o $\mathrm{pH}$ do meio foi ajustado em 8 . 
Tabela 4.2. Composição do meio basal de cultivo.

\begin{tabular}{lc}
\hline \multicolumn{1}{c}{ Componentes } & Quantidades - q.s.p. 1000mL de água ultrapurificada \\
\hline$\left(\mathrm{NH}_{4}\right)_{2} \mathrm{SO}_{4}$ & $330 \mathrm{mg}(5 \mathrm{mM})$ \\
$\mathrm{NaNO}_{2}$ & $345 \mathrm{mg}(5 \mathrm{mM})$ \\
$\mathrm{KHCO}_{3}$ & $500 \mathrm{mg}$ \\
$\mathrm{KH}_{2} \mathrm{PO}_{4}$ & $27,2 \mathrm{mg}$ \\
$\mathrm{MgSO}_{4} \cdot 7 \mathrm{H}_{2} \mathrm{O}$ & $300 \mathrm{mg}$ \\
$\mathrm{CaCl}_{2} \cdot 2 \mathrm{H}_{2} \mathrm{O}$ & $180 \mathrm{mg}$ \\
Solução traço I & $1 \mathrm{ml}$ \\
Solução traço II & $1 \mathrm{ml}$ \\
\hline
\end{tabular}

Fonte: VAN DE GRAAF et al., (1996)

Tabela 4.3. Composição da Solução Traço I.

\begin{tabular}{|c|c|}
\hline Componentes & Quantidades - q.s.p. $1000 \mathrm{~mL}$ de água ultrapurificada \\
\hline EDTA & $5 \mathrm{~g}$ \\
\hline $\mathrm{FeSO}_{4}$ & $5 \mathrm{~g}$ \\
\hline
\end{tabular}

Fonte: VAN DE GRAAF et al., (1996)

Tabela 4.4. Composição da Solução Traço II.

\begin{tabular}{lc}
\multicolumn{1}{c}{ Componentes } & Quantidades - q.s.p. 1000mL de água ultrapurificada \\
\hline EDTA & $15 \mathrm{~g}$ \\
$\mathrm{ZnSO}_{4} \cdot 7 \mathrm{H}_{2} \mathrm{O}$ & $0,43 \mathrm{~g}$ \\
$\mathrm{CoCl}_{2} \cdot 6 \mathrm{H}_{2} \mathrm{O}$ & $0,24 \mathrm{~g}$ \\
$\mathrm{MnCl}_{2} \cdot 4 \mathrm{H}_{2} \mathrm{O}$ & $0,99 \mathrm{~g}$ \\
$\mathrm{CuSO}_{4} \cdot 5 \mathrm{H}_{2} \mathrm{O}$ & $0,25 \mathrm{~g}$ \\
$\mathrm{NaMoO}_{4} \cdot 2 \mathrm{H}_{2} \mathrm{O}$ & $0,22 \mathrm{~g}$ \\
$\mathrm{NiCl}_{2} \cdot 6 \mathrm{H}_{2} \mathrm{O}$ & $0,19 \mathrm{~g}$ \\
$\mathrm{Na}_{2} \mathrm{SeO}_{3}$ & $0,09 \mathrm{~g}$ \\
$\mathrm{H}_{3} \mathrm{BO}_{3}$ & $0,014 \mathrm{~g}$ \\
\hline
\end{tabular}

Fonte: Adaptado de VAN DE GRAAF et al., (1996).

\subsection{OPERAÇÃO DOS QUIMIOSTATOS ANAMMOX}

Foram utilizados quimiostatos com volume de $2000 \mathrm{~mL}$ (Figura 4.2) para enriquecimento dos lodos. O headspace de $25 \%$ foi preenchido com Argônio (100\%), $210 \mathrm{~mL}$ de pérolas de vidro e $1540 \mathrm{~mL}$ de volume útil (meio de cultivo + lodo).

$\mathrm{O}$ enriquecimento foi realizado com a finalidade de obter elevada concentração de 
biomassa anammox. A vazão afluente nos quimiostatos foi de $18 \mathrm{ml} / \mathrm{h}$. TOH et. al., (2002) utilizaram faixa de 12 a 25mL/h e tempo de detenção hidráulica (TDH) de 85,5 horas. Esta reduzida vazão deve se ao elevado tempo de geração das bactérias anammox, o qual oscila entre 11-29 dias (Strous et al., 1998).

Os quimiostatos foram confeccionados em boro silicato com $2 \mathrm{~mm}$ de espessura e tampas em teflon. Os dois quimiostatos receberam meio sintético bombeado do frasco de alimentação mantido a $4^{\circ} \mathrm{C}$ para se evitar a mudança do bicarbonato para a fase gasosa. A vazão afluente refletiu carga de nitrogênio de 60,48mg $\left(\mathrm{N}-\mathrm{NO}_{2}^{-}+\mathrm{N}-\mathrm{NH}_{4}{ }^{+}\right) /$dia. Os quimiostatos foram colocados em estufa com temperatura controlada a $37 \pm 1^{\circ} \mathrm{C}$.

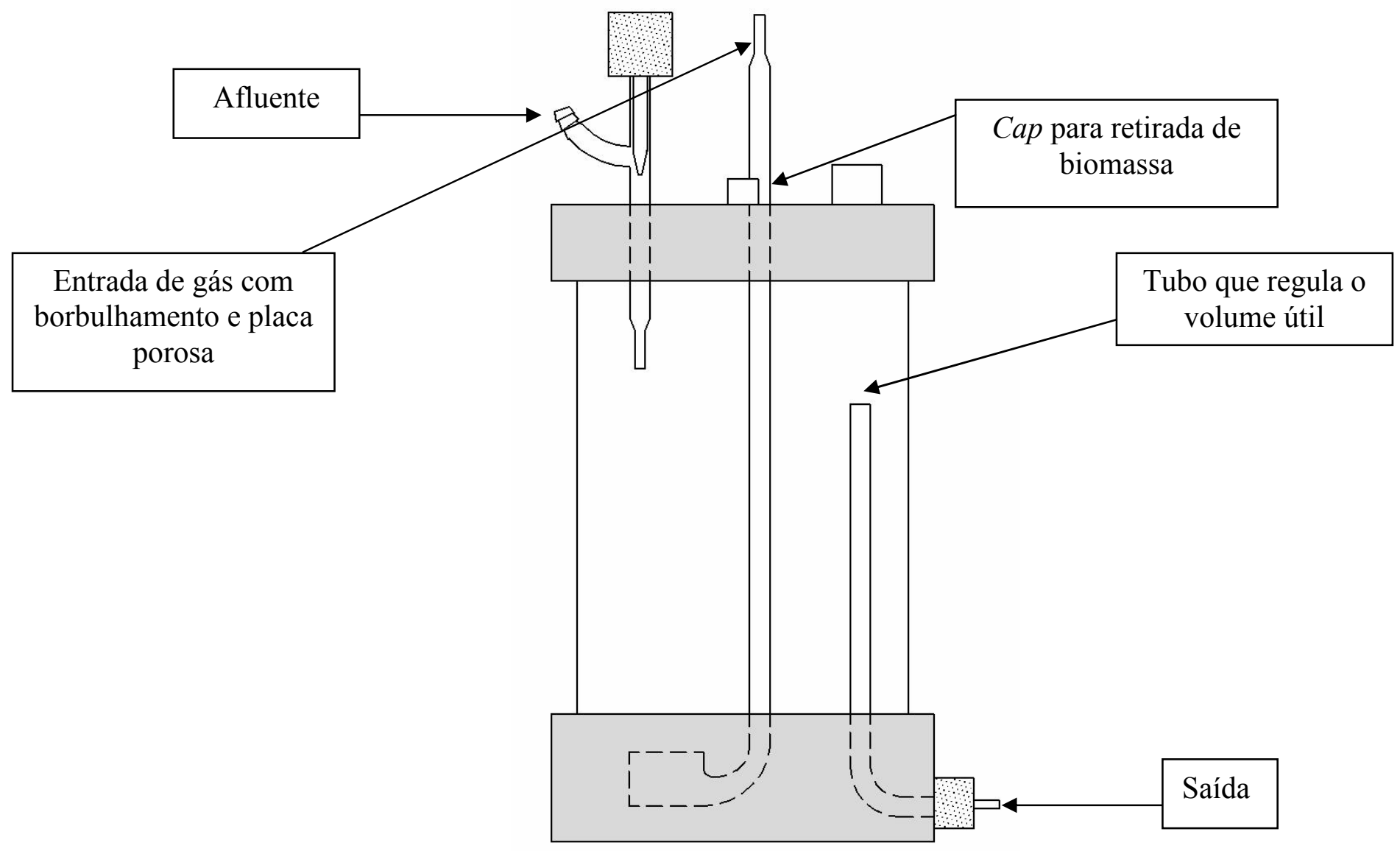

Figura 4.2. Esquema do quimiostato.

Como material suporte para imobilização da biomassa foram usadas pérolas de vidro com diâmetro entre 2 e $4 \mathrm{~mm}$. As pérolas foram transferidas para Becker de polipropileno e durante 30 minutos e mergulhadas em solução $10 \%$ de ácido fluorídrico. A cada 5 minutos as perolas eram revolvidas com tubo de PVC, com finalidade de favorecer o contato com o ácido e, conseqüentemente, aumentar a rugosidade para imobilização celular (Figura 4.3). 
Após o ataque ácido, as pérolas foram lavadas várias vezes com água de torneira e destilada, transferidas para estufa de secagem e, então colocadas para imobilização.

Os inóculos foram homogeneizados separadamente em liquidificador doméstico e transferidos para cada quimiostato visando à imobilização nas pérolas de vidro. Imediatamente após a transferência dos inóculos para os quimiostatos foi iniciado o enchimento e a alimentação na vazão descrita acima.

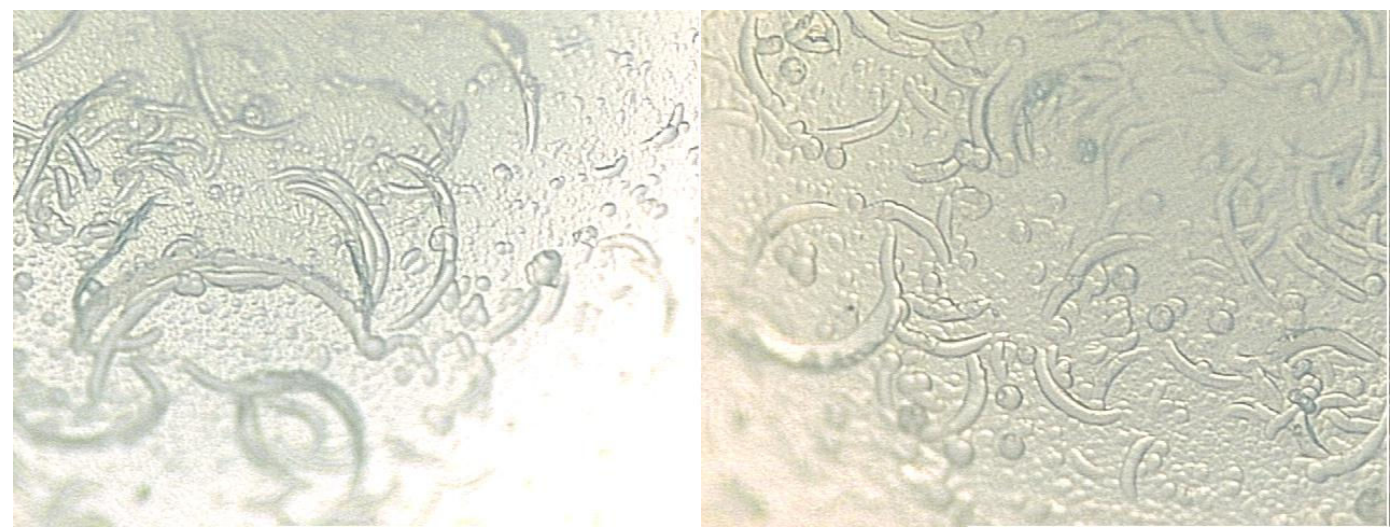

Figura 4.3. Microscopia óptica de campo claro da superfície das pérolas de vidro após ataque de ácido fluorídrico (aumento de 100 vezes).

\subsection{EXAMES MICROSCÓPICOS}

Exames microscópicos foram realizados em microscopia óptica comum, de contraste de fase e epifluorescência utilizando Microscópio Olymphus BX60, acoplado a câmera com captura de imagem e software Image-Pro Plus. A partir do $109^{\circ}$ dia de operação, as amostras coletadas do quimiostatos foram transferidas para frascos de antibióticos com pérolas de vidro e agitadas para desprendimento do biofilme, visando melhorar a visualização das células.

Exames utilizando técnica de coloração de Gram foram realizados segundo DSM (1991).

\subsection{ANÁLISES FÍSICO-QUÍMICAS}

As análises de amônia, nitrato e nitrito foram realizadas segundo Standard Methods for the Examination of Water and Wastewater (1998), duas vezes por semana. A partir de 116 dias de operação as análises foram feitas por análise por injeção em fluxo (FIA) proposto pelo Standard Methods for the Examination of Water and Wastewater (1998).

A determinação dos sólidos totais voláteis foi realizada no início e final da operação dos quimiostatos de acordo com metodologia do Standard Methods for the Examination of Water and Wastewater (1998). 
$\mathrm{O} \mathrm{pH}$ e potencial REDOX foram analisados utilizando aparelho Digimed modelo DM-21. Foi utilizado eletrodo combinado de platina Pt4805 da Mettler-Toledo. O pH foi analisado toda vez que meio de cultivo fresco foi submetido à alimentação. $O$ potencial redox foi medido uma vez por semana.

\subsection{PURIFICAÇÃO}

Métodos de purificação tradicionais falharam para culturas anammox. Desse modo, os ensaios de purificação foram feitos de acordo com protocolo utilizado por STROUS et al. (1999a). Esse protocolo consiste na desagregação do biofilme por banho ultrassônico, separação das células dos fragmentos do biofilme e purificação celular usando gradiente de densidade por centrifugação Percoll (Tabela 4.5).

Tabela 4.5. Protocolo de purificação da cultura anammox.

Etapas da purificação

1. O biofilme foi lavado em 40mL de tampão HEPES/bicarbonato (70/10 mM e pH 7,8).

2. Após a lavagem, o material foi transferido para banho de ultra-som em porções de $5 \mathrm{~mL}$ durante 1 minuto e 30 segundos (biomassa imobilizada) e potência de $50 \mathrm{~W}$.

3. A amostra foi transferida para frasco apropriado e procedeu-se a centrifugação durante 5 minutos a $10.000 \mathrm{~g}$. Foram observados gradiente de coloração constituído pelo sobrenadante laranja com fragmentos do biofilme e pellet avermelhado contendo as células separadas.

4. O pellet foi lavado com solução HEPES/bicarbonato $(70 / 10 \mathrm{mM}$ e $\mathrm{pH} 7,8)$. A amostra foi purificada usando centrifugação Percoll, sendo 6,9mL de Percoll (Pharmacia) e $3,1 \mathrm{ml}$ de suspensão celular. A amostra foi submetida a centrifugação durante 60 minutos a $10.000 \mathrm{~g}$ e $5^{\circ} \mathrm{C}$.

5. A banda vermelha formada na região inferior do frasco de centrifugação foi retirada e submetida à lavagem com o tampão estéril.

Fonte: Adaptado de STROUS et al., 1999.

\subsection{TÉCNICAS DE BIOLOGIA MOLECULAR}

\subsubsection{Hibridação in situ com Sondas Fluorescentes}

A sonda utilizada para confirmação do consórcio anammox foi a S-*-Amx-0368-aA-18 descrita por SCHMID et al. (2003). Esta sonda é a mais abrangente e hibridiza todos os organismos anammox descritos até a presente data. As amostras foram coradas com DAPI e hibridadas com a sonda Amx 368.

As amostras foram lavadas em PBS duas vezes. A fixação das amostras foi realizada em tampão de fixação, contendo solução PBS (Phosphate-Buffered Saline, Tampão Fosfato Salino, 75,985g NaCl/L, 9,9372g Na $\mathrm{HPO}_{4} / \mathrm{L}$ e 3,5994g $\mathrm{NaH}_{2} \mathrm{PO}_{4} / \mathrm{L} \mathrm{pH=7,2)} \mathrm{e} \mathrm{4 \% (v/v)} \mathrm{de}$ 
paraformaldeído durante 14 horas a $4^{\circ} \mathrm{C}$. Após a fixação procedeu-se a lavagem e centrifugação $\left(9000 \mathrm{rpm}\right.$ a $\left.4^{\circ} \mathrm{C}\right)$ da amostra em tampão $\mathrm{PBS}$, por 3 vezes. O pellet foi ressuspendido em $500 \mu \mathrm{L}$ de etanol e $500 \mu \mathrm{L}$ de PBS. As amostras foram armazenadas em freezer a $-20^{\circ} \mathrm{C}$.

Cinco microlitros, de cada amostra fixada, foram colocados em cada pocinho da lâmina de hibridação recoberta com gelatina, secos durante $20 \mathrm{~min}$. à $45^{\circ} \mathrm{C}$ e desidratados em soluções 50, 80 e 100\% de etanol, três minutos cada solução.

A hibridação e lavagem foram conduzidas segundo Tabela 4.6 utilizando protocolo descrito por EGLI et al. (2003) (Figura 4.4). As células hibridadas foram visualizadas em microscópio OLIMPUS BX 60 com filtro WG. Para coloração com DAPI foi utilizado filtro WU.

Tabela 4.6. Soluções Tampão de hibridação e lavagem utilizadas na técnica FISH.

\begin{tabular}{lll}
\hline Sonda & Tampão de Hibridação & Tampão de Lavagem \\
\hline & $0,9 \mathrm{M} \mathrm{NaCl}$ & $338 \mathrm{mM} \mathrm{NaCl}$ \\
& $20 \mathrm{mM}$ Tris- $\mathrm{HCl}(\mathrm{pH}=7,2)$ & $20 \mathrm{mM}$ Tris- $\mathrm{HCl}(\mathrm{pH}=7,2)$ \\
S-*-Amx-0368-a-A-18 & $0,01 \%$ SDS & $0,01 \% \mathrm{SDS}$ \\
& $10 \mathrm{mM}$ EDTA & $5 \mathrm{mM}$ EDTA \\
& $15 \%(\mathrm{v} / \mathrm{v})$ Formamida & \\
\hline Tempo e temperatura & $90 \mathrm{~min} .46^{\circ} \mathrm{C}$ & $10 \mathrm{~min} .48^{\circ} \mathrm{C}$ \\
\hline
\end{tabular}

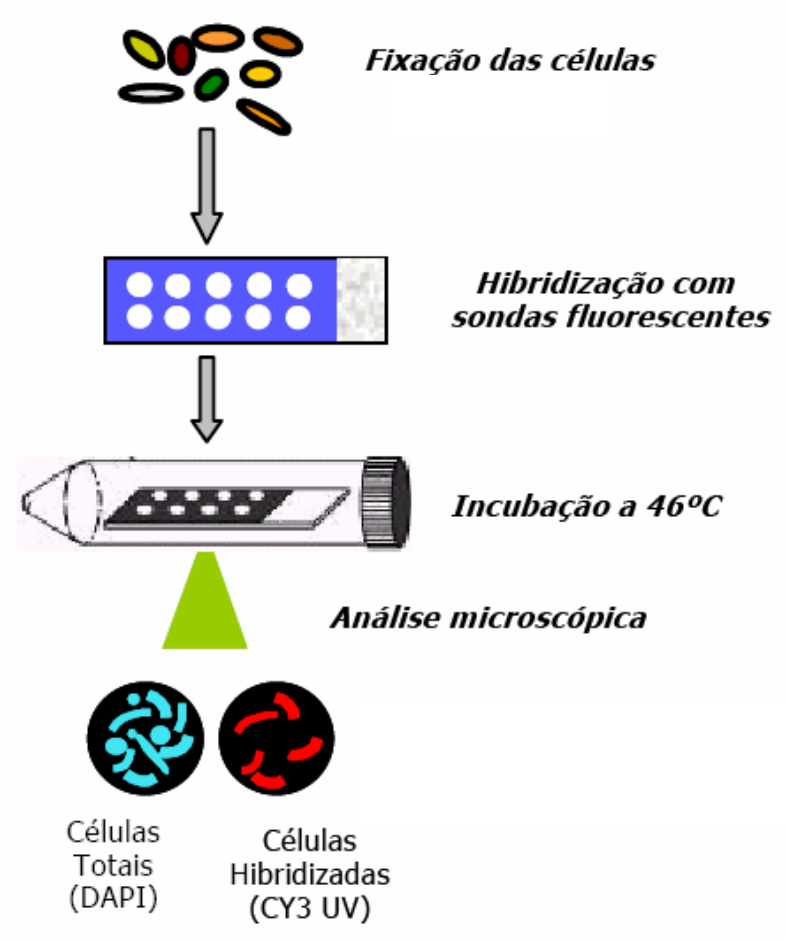

Figura 4.4. Representação esquemática do FISH. Fonte: Adaptado de KIELING (2004). 


\subsubsection{Análises da Diversidade dos Consórcios Microbianos}

A análise dos consórcios microbianos presentes nos dois quimiostatos foi realizada utilizando técnica de reação em cadeia da polimerase e eletroforese em gel de gradiente desnaturante (PCR/DGGE), conforme Figura 4.5.

A extração de DNA foi realizada através do método direto, utilizando "glass beads" e mistura de fenol: clorofórmio:tampão fosfato salino $(1: 1: 1 \mathrm{v} / \mathrm{v})$, seguindo o procedimento descrito por MELVIN \& HOBSON (1994) (Tabela 4.7).

As amostras de DNA obtidas pelo protocolo de extração foram visualizadas em gel de agarose $1 \%$, corados com brometo de etídio e observadas em fotodocumentador Eagle Eye TM III (Stratagene) acoplado ao computador e software Eagle Slight para visualização de bandas, sob exposição à UV $(254 \mathrm{~nm})$.

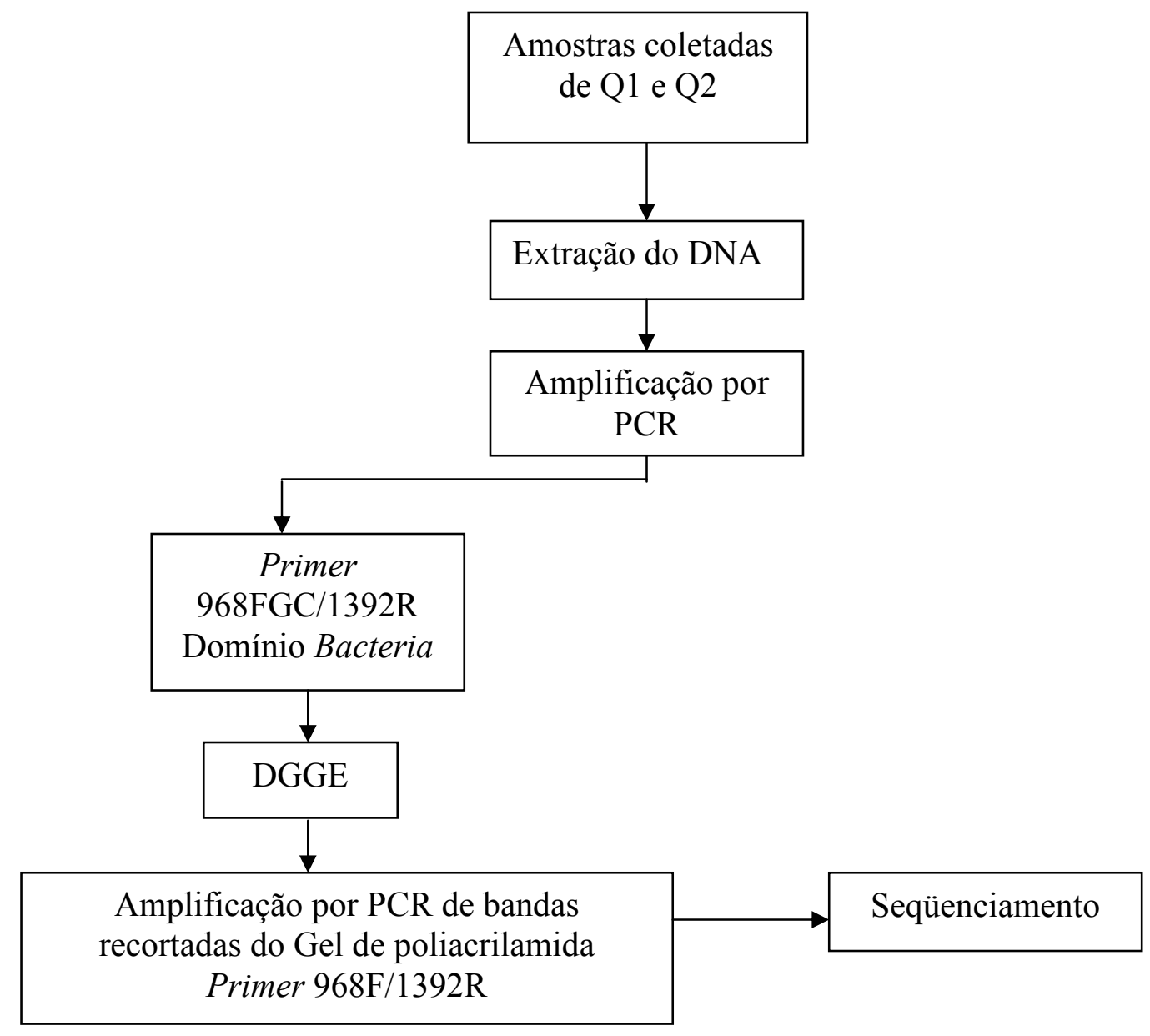

Figura 4.5. Fluxograma da análise dos consórcios microbianos presentes em Q1 e Q2 utilizando técnica PCR/DGGE. 
Tabela 4.7. Protocolo de extração de DNA.

\begin{tabular}{|c|c|}
\hline Passo & Procedimento \\
\hline 1 & $\begin{array}{l}5 \mathrm{ml} \text { da amostra foi transferida para tubos Falcon }(15 \mathrm{~mL}) \text { e submetidas a } \\
\text { centrifugação por } 10 \text { minutos, a } 6000 \mathrm{rpm} \text { e temperatura de } 4^{\circ} \mathrm{C} \text {; }\end{array}$ \\
\hline 2 & $\begin{array}{l}\text { O sobrenadante foi descartado e o precipitado submetido a lavagem com } \\
\text { tampão PBS } 1 \mathrm{X} \text { em centrífuga por } 10 \text { minutos a } 6000 \mathrm{rpm} \text { e temperatura de } \\
4^{\circ} \mathrm{C} \text {; }\end{array}$ \\
\hline 3 & O sobrenadante foi desacartado; \\
\hline 4 & $\begin{array}{l}\text { Ao precipitado foi adicionado os seguintes materiais: } 0,5 \mathrm{~g} \text { de Glass Beads } \\
(150-212 \mu \mathrm{m}), 1 \mathrm{~mL} \text { de fenol tamponado (equilibrado com Tris), } 1 \mathrm{~mL} \text { de } \\
\text { clorofórmio e } 1 \mathrm{~mL} \text { de PBS (1X), a partir deste momento os tubos com } \\
\text { amostras sempre foram mantidos em gelo; }\end{array}$ \\
\hline 5 & As amostras foram agitadas no vórtex; \\
\hline 6 & $\begin{array}{l}\text { Foi feita uma seqüência de extração de DNA para descobrir o melhor tempo } \\
\text { de extração. Os tempos considerados foram os seguintes: } 20,40,60,80,100 \\
\text { e } 120 \text { segundos. O melhor tempo de extração encontrado foi de sessenta } \\
\text { segundos; }\end{array}$ \\
\hline 7 & $\begin{array}{l}\text { As amostras foram submetidas a centrifugação por } 10 \text { minutos, a } 6000 \mathrm{rpm} \\
\text { e temperatura de } 4{ }^{\circ} \mathrm{C} \text {; }\end{array}$ \\
\hline 8 & $\begin{array}{l}\text { A camada líquida }(<1 \mathrm{~mL}) \text { foi removida e transferida para tubo eppendorf } \\
(2 \mathrm{~mL}) ;\end{array}$ \\
\hline 9 & $\begin{array}{l}\text { Solução tamponada de fenol }(1,0 \mathrm{~mL}) \text { foi adicionada e submetida a agitação } \\
\text { no vórtex. } \mathrm{O} \text { material foi centrifugado por } 10 \text { minutos, a } 10000 \mathrm{rpm} \text { e } \\
\text { temperatura de } 4^{\circ} \mathrm{C} \text {. }\end{array}$ \\
\hline 10 & $\begin{array}{l}\text { O sobrenadante foi transferido para outro tubo, no qual foi adicionado } 1,0 \\
\mathrm{~mL} \text { de clorofórmio. Procedeu-se a agitação no vórtex e centrifugação por } 10 \\
\text { minutos a } 10000 \mathrm{rpm} \text { e temperatura de } 4^{\circ} \mathrm{C} \text {; }\end{array}$ \\
\hline 11 & O passo anterior foi repetido; \\
\hline 12 & $\begin{array}{l}\text { A camada superior (DNA) foi transferida para frasco apropriado e mantida } \\
\mathrm{a}-20^{\circ} \mathrm{C} \text {. }\end{array}$ \\
\hline
\end{tabular}




\subsubsection{Reação em Cadeia da Polimerase e Eletroforese em Gel de Gradiente}

Desnaturante (PCR/DGGE)

A amplificação dos fragmentos de DNA ribossomal 16S foi realizada utilizando-se primers universais para o Domínio Bacteria. Os produtos de PCR com primers universais foram separados por Eletroforese em Gel por Gradiente Desnaturante (DGGE), que separa iguais fragmentos de DNA pela concentração de $\mathrm{G}+\mathrm{C}$ no fragmento amplificada, então fragmentos com maior quantidade de $\mathrm{G}+\mathrm{C}$ situam-se na região do gel onde tem maior concentração de desnaturante (formamida e uréia).

Cada reação de amplificação do DNAr 16S foi realizada utilizando as seguintes soluções: $0,5 \mu \mathrm{L}$ “Taq DNA polimerase Platinum” $(5 \mathrm{U} / \mu \mathrm{L}), 5 \mu \mathrm{L}$ de tampão PCR 10X, $1,5 \mu \mathrm{L}$ de $\mathrm{MgCl}_{2}(50 \mathrm{mM}), 5 \mu \mathrm{L}$ de dNTPs ( $2 \mathrm{mM}$ de cada uma), $0,5 \mu \mathrm{L}$ de "primer forward" (100pmol) , 0,5 $\mathrm{L} \mathrm{L}$ de "primer reverse" (100pmol) e $2 \mu \mathrm{L}$ de DNA extraído. O volume final de reação foi $50 \mu \mathrm{L}$ completado com água estéril livre de nuclease PROMEGA. Para reação de amplificação foi usado Kit de reação "Platinum" (Invitrogem). A amplificação foi realizada em termociclador "Gene Amp. PCR System 2400" (Perkin-Elmer Cetus, Norwalk, Conn.).

O seqüenciamento foi feito a partir das bandas recortadas do DGGE com fragmentos de DNA amplificados pelos primers conforme Tabela 4.8. Para seqüenciamento, as bandas recortadas do gel de poliacrilamida foram imersas em água estéril livre de nuclease a $4^{\circ} \mathrm{C}$ durante 48 h para eluição do DNA em água. Essa água com DNA eluído foi utilizada para nova amplificação com mesmos primers, porém sem GC clamp. Esse produto de PCR foi purificado, para se retirar resíduos de dNTPs, enzimas, e primers, utilizando Kit UltraClean $^{\mathrm{TM}}$ PCR Clean-up (MoBio Laboratories, Inc. CA) conforme instruções do fabricante. As amostras de DNA purificadas foram seqüenciadas em seqüenciador automático ABI PRISM 310.

Tabela 4.8. Primers utilizados para DGGE.

\begin{tabular}{lccc}
\hline Primers & Grupo & Seqüência $\left(5^{\prime} \rightarrow 3^{\prime}\right)$ & Referência \\
\hline 968FGC & & AACCGCGAAGAACCTTAC & \\
GC clamp & Domínio & CGCCCGGGGCGCGCCCCGGGCGG & \\
& Bacteria & GGCGGGGGCACGGGGGG & Nielsen et al. (1999). \\
& & & \\
1392R & & CCTTTCGGGCATTGCGAA & \\
\hline
\end{tabular}


As seqüências obtidas foram agregadas e averiguadas usando DNASTAR-package Software (Lasergene Sequence Analysis). Após averiguação, as seqüências de nucleotídeo foram comparadas com seqüências do banco de dados eletrônico NCBI-database para a aproximação por similaridade.

As seqüências com maior similaridade genética foram agrupadas e alinhadas aos pares e multiplamente em software ClustalW versão 1.83 para Linux em processador Pentium 4 Northwood com $2.0 \mathrm{Ghz}$ de clock e $1 \mathrm{~Gb}$ de $R A M$. Depois de alinhadas as seqüências foram arranjadas em forma de árvore filogenética utilizando-se método de máxima verossimilhança em software PHYLIP 3.61 com Bootstrap de 150 reamostragens.

\section{RESULTADOS E DISCUSSÃO}

\subsection{CARACTERISTICAS GERAIS DOS CONSÓCIOS ENRIQUECIDOS}

No consórcio enriquecido no quimiostato Q1 (inóculo - lodo de reator UASB de abatedouro de aves) a maioria das células estava aderida ao polímero de biofilme, dificultando a visualização. Raras células eram encontradas em suspensão (planctônicas). Foram observadas morfologias variadas, tais como bacilos pleomórficos, provavelmente devido a adaptação às novas condições presentes no quimiostato, bacilos (Figura 5.1), cocos agrupados (Figura 5.2a e 5.3a), filamentos (Figura 5.2b) e coco-bacilos e cocos em matriz extracelular (Figura 5.3b).

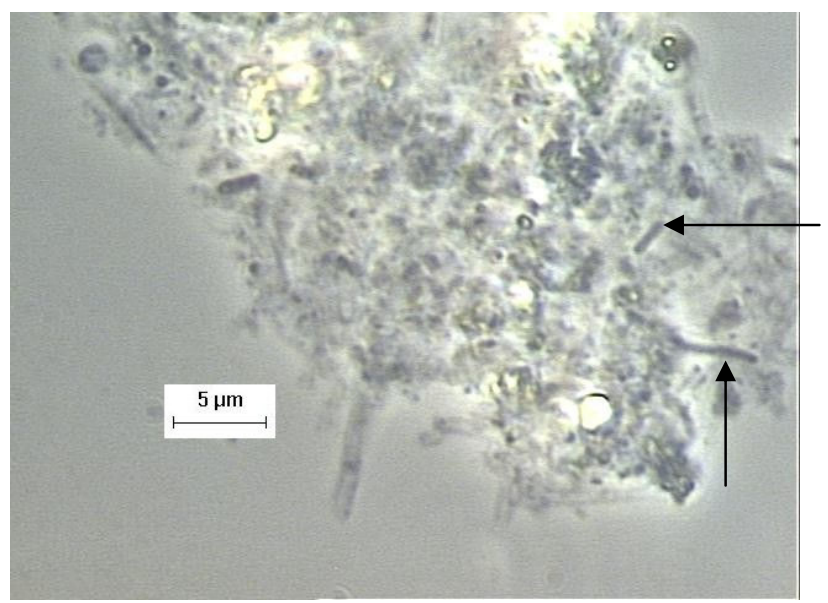

Figura 5.1. Microscopia de contraste de fase da biomassa crescida em Q1 após 70 dias de operação. 


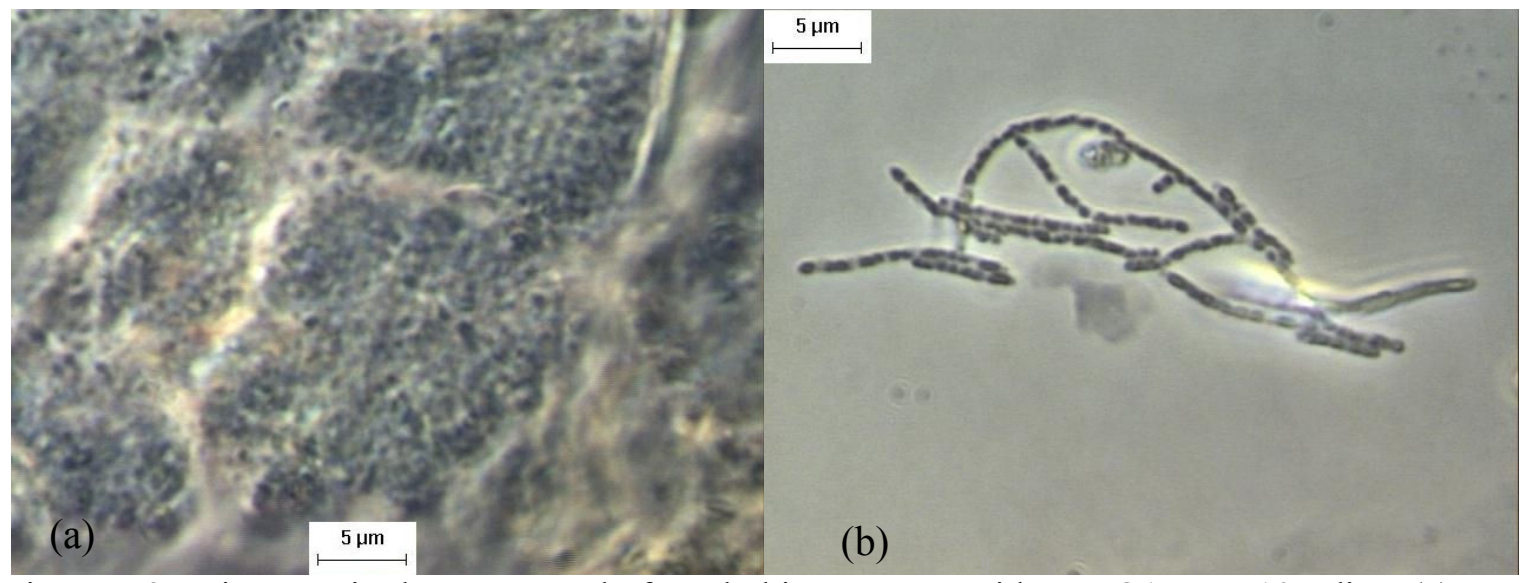

Figura 5.2. Microscopia de contraste de fase da biomassa crescida em Q1 após 105 dias: (a) cocos agrupados; (b) filamentos.

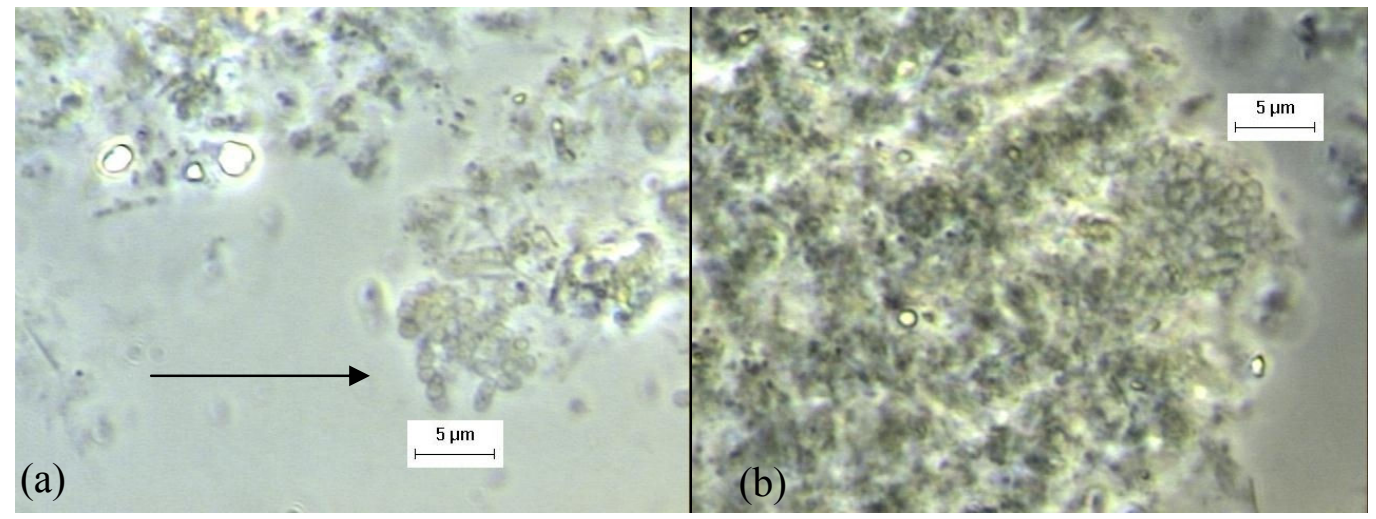

Figura 5.3. Microscopia de contraste de fase da biomassa crescida em Q1 após 105 dias: (a) cocos agrupados; (b) coco-bacilos e cocos em matriz extracelular.

Nos exames microscópicos mostrados nas Figuras 5.1 a 5.3, a biomassa foi observada sem nenhum tratamento prévio para desprender as células do biofilme. A Figura 5.4 mostra a biomassa presente em Q1, após desprendimento do biofilme, com predomínio de aglomerados celulares de cocos envoltos por matriz extracelular, assim como descrito por EGLI et al. (2001) e Schmid et al. (2000). Os aglomerados envolvidos por matriz extracelular encontrado por EGLI et al. (2001) tinham diâmetro médio de $17 \mu \mathrm{m}$, enquanto os encontrados em Q1 tinham diâmetro variando de 10 a $15 \mu \mathrm{m}$. Na Figura 5.4a, observa-se esta matriz extracelular rompida, e novos aglomerados se formando (Figura 5.4b). Foram encontrados, também, filamentos (Figura 5.4c) após 109 dias de operação. 


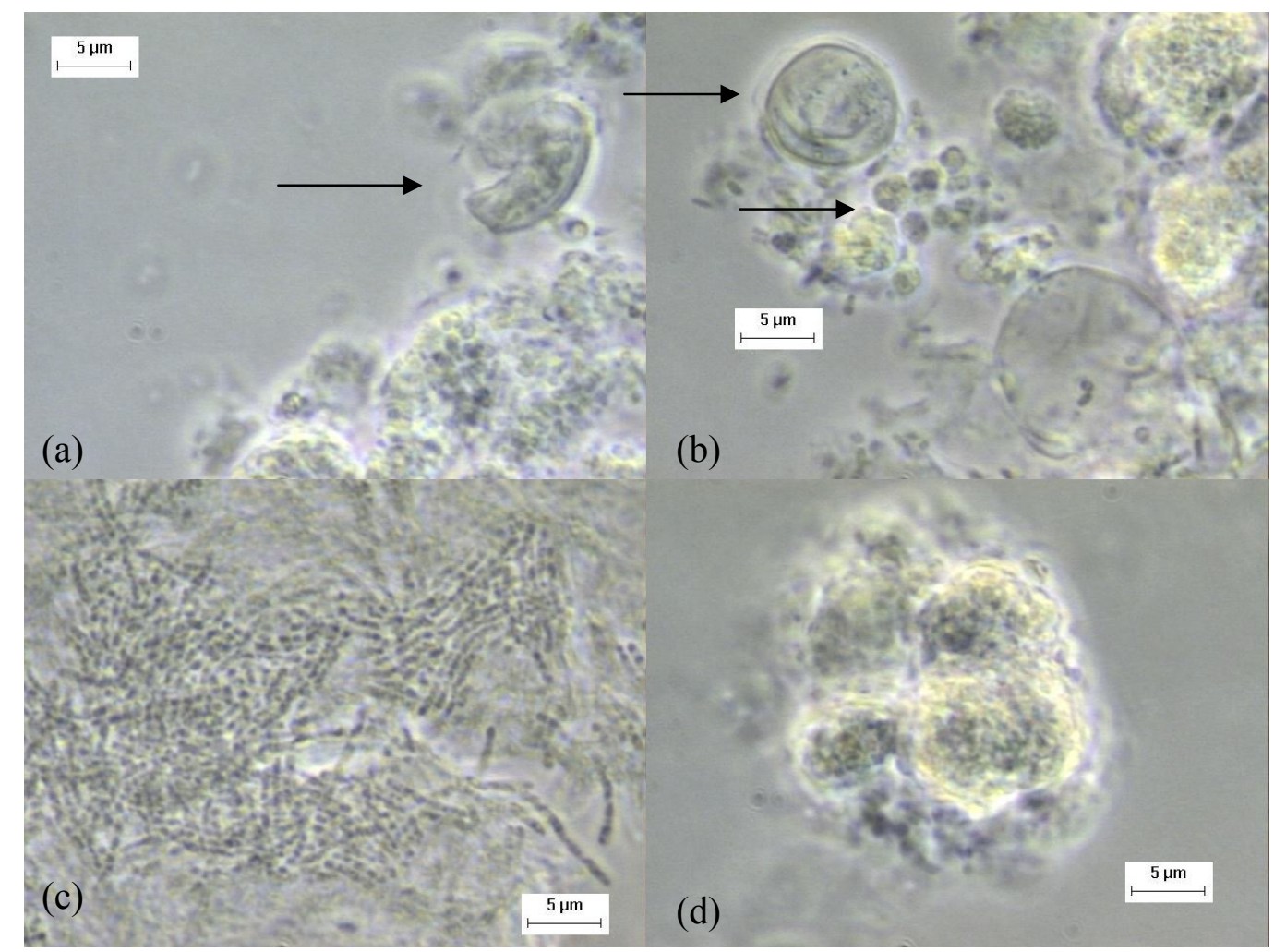

Figura 5.4. Microscopia de contraste de fase da biomassa crescida em Q1 após 109 dias: (a) matriz extracelular rompida; (b) novos aglomerados se formando; (c) filamentos; (d) cocos aglomerados.

Após 148 dias de operação do Q1 foi realizado exame microscópico para coloração de Gram. A maioria das células observadas eram Gram negativas, com alguns bacilos Gram positivos (Figura 5.5a e 5.5d). As Figuras 5.5a, 5.5b e 5.5c revelam que o aglomerado de cocos foi Gram negativo, semelhante ao observado por STROUS et al. (2006) para bactérias anammox da ordem Planctomycetales. 
(a)

$$
5 \mu \mathrm{m}
$$

(c)
$5 \mu \mathrm{m}$

(b)

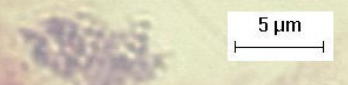

\section{$5 \mu \mathrm{m}$}

Figura 6.5. Coloração de Gram em microscopia de campo claro da biomassa crescida em Q1 após 148 dias.

O consórcio enriquecido em Q2 (inoculo - biomassa de reator nitrificante desnitrificante de industria alimentícia) apresentou morfologias variadas. Os primeiros exames microscópicos foram realizados com 70 dias de operação. A visualização das células foi difícil, assim como em Q1, porém havia muito debris celulares e as mesmas encontravam-se agregadas (Figura 5.6 e $5.7 \mathrm{c}$ ). Neste período, ainda ocorria lavagem do lodo. A Figura 5.7 mostra morfologias tais como: bacilos pleomórficos (Figura 5.6a) e bacilos, cocos e filamentos (Figura 5.7b), e aglomerado de cocos (Figura 5.7d). Nas amostras retiradas de Q2 com 70 e 105 dias de operação, foram visualizadas raras células (Figuras 5.6 e 5.7). Para estas microfotografias, foi necessário percorrer muitos campos de visualização na lâmina contendo amostra. 


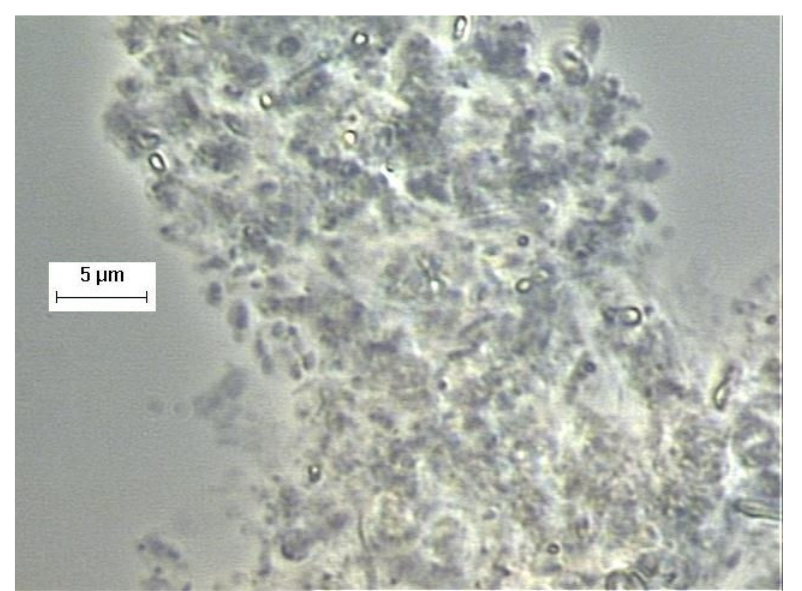

Figura 5.6. Microscopia de contraste de fase da biomassa crescida em Q2 após 70 dias de operação.

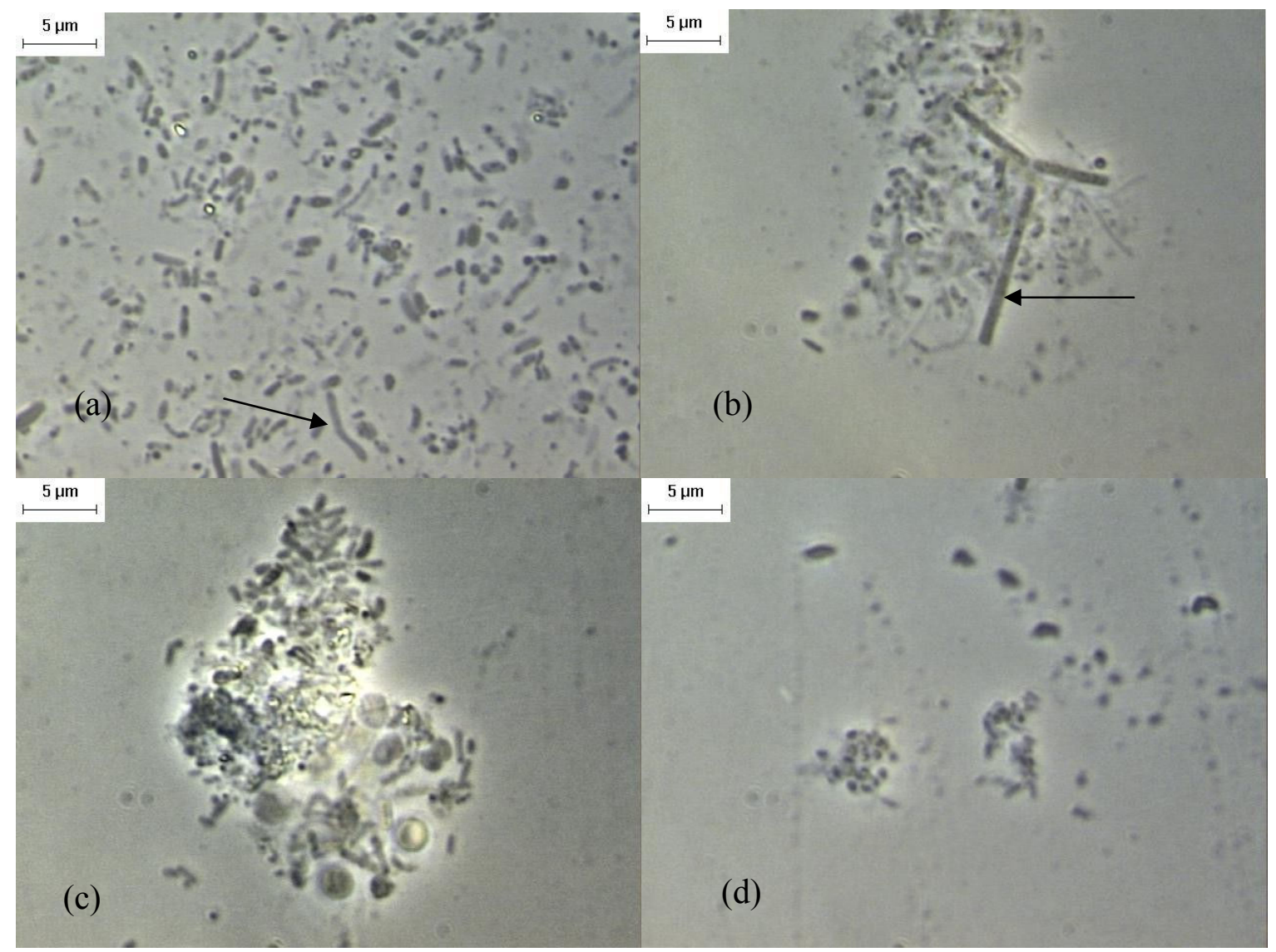

Figura 5.7. Microscopia de contraste de fase da biomassa crescida em Q2 após 105 dias: (a) bacilos pleomórficos; (b) filamentos; (c) biofilme de células aglomeradas; (d) cocos agrupados.

As Figuras 5.8 e 5.9a mostram a biomassa presente no quimiostato 2, após 109 dias de operação. Após desprendimento do biofilme, como descrito anteriormente, observou-se predomínio da mesma morfologia encontrada em Q1. A Figura 5.9b revela células suspensas (sem matriz extracelular). Vale a pena ressaltar que estes aglomerados celulares, com diâmetro variando de 10 a $30 \mu \mathrm{m}$, visualizados após o desprendimento celular do biofilme, estavam presentes nas amostras anteriores, todavia, camuflados pelo biofilme. 


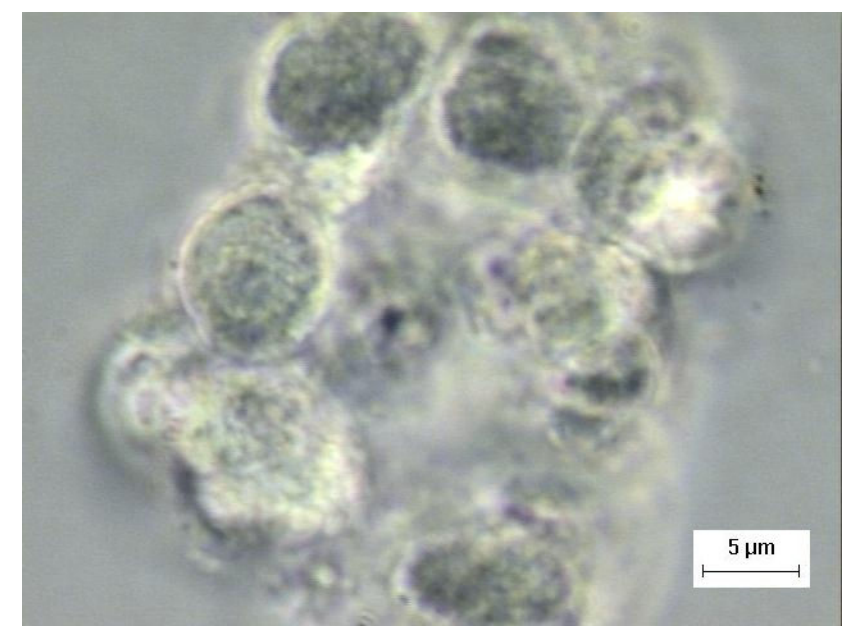

Figura 5.8. Microscopia de contraste de fase da biomassa crescida em Q2 após 109 dias.

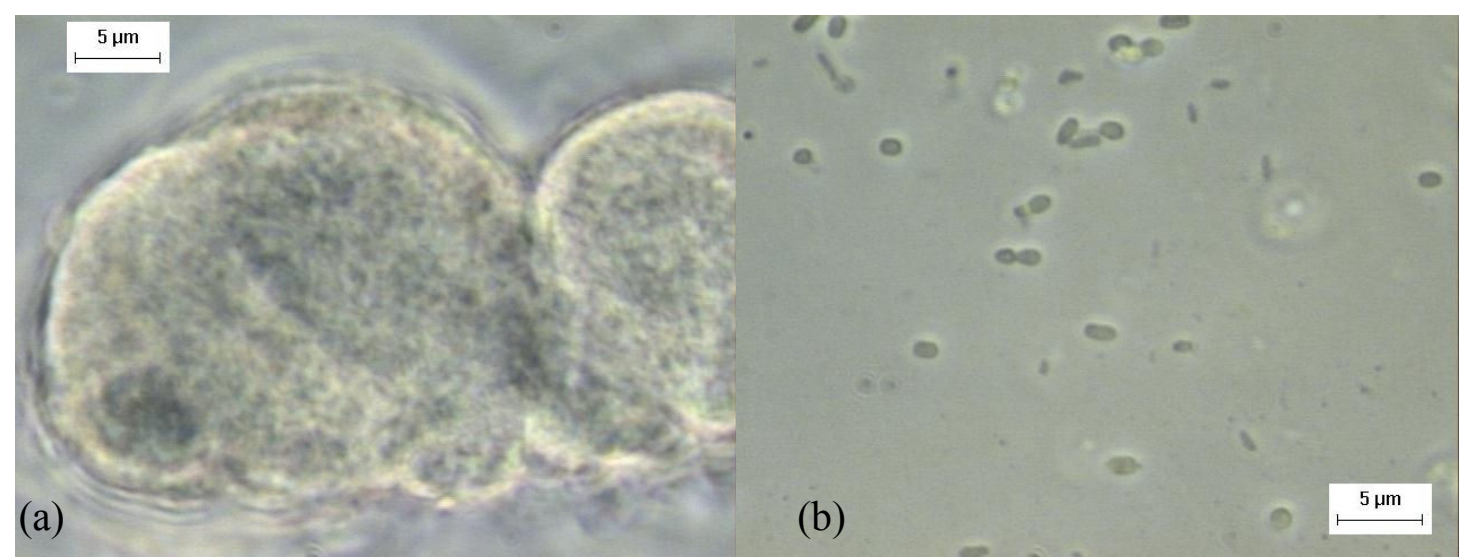

Figura 5.9. Microscopia de contraste de fase da biomassa crescida em Q2 após 109 dias: (a) cocos aglomerados; (b) cocos e coco-bacilos suspensos.

Exame de microscopia de campo claro, com a biomassa submetida à coloração de Gram, revelou aglomerados de cocos Gram negativos, além de cocos e bacilos Gram positivos (Figura 5.10b).

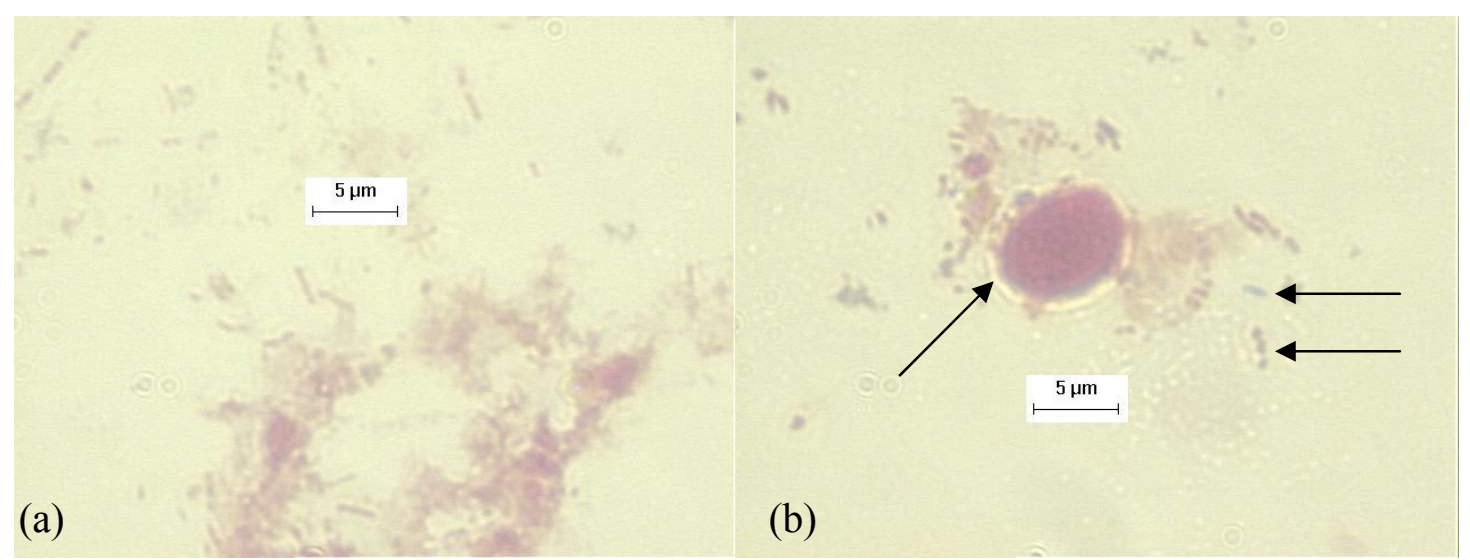

Figura 5.10. Coloração de Gram em microscopia de campo claro da biomassa crescida em Q2 após 148 dias: (a) células planctônicas Gram negativas; (b) aglomerado de cocos Gram negativos e bacilos Gram positivos. 


\subsection{OPERAÇÃO DOS QUIMIOSTATOS}

Durante os primeiros 17 dias de operação não foi realizada nenhuma análise no efluente dos quimiostatos, pois os dois efluentes (de Q1 e de Q2) eram constituídos por elevada concentração de sólidos suspensos devido ao arraste de lodo biológico.

As concentrações inicial e final em cada quimiostato estão expostas na Tabela 5.1. Os resultados indicaram que tanto no Q1 quanto no Q2 ocorreu diminuição das concentrações de sólidos. No entanto, Q1 teve maior perda de biomassa (48\%) que Q2, com perda de aproximadamente $28 \%$ da biomassa inicial. As condições usadas na alimentação dos quimiostatos foram altamente seletivas, pois mesmo após 316 dias de operação a concentração da biomassa nos quimiostatos não se elevou.

Tabela 5.1. Concentração da biomassa como STV nos quimiostatos.

\begin{tabular}{ccc}
\hline Quimiostato & $\begin{array}{c}\text { Concentração inicial no quimiostato } \\
(\mathrm{gSTV} / \mathrm{L})\end{array}$ & $\begin{array}{c}\text { Concentração final no quimiostato } \\
(\mathrm{gSTV} / \mathrm{L})\end{array}$ \\
\hline 1 & 6,22 & 3,23 \\
2 & 2,06 & 1,48 \\
\hline
\end{tabular}

Os valores de $\mathrm{pH}$ obtidos nos efluentes dos quimiostatos mantiveram-se na faixa de 7,5 a 8,9 . Muitas vezes o $\mathrm{pH}$ efluente era maior que o afluente. $\mathrm{O} \mathrm{pH}$ afluente sempre esteve entre 7,8 e 8,1

O potencial redox, analisado no meio reacional (dentro do quimiostato) esteve sempre na faixa de $-18 \mathrm{a}+127 \mathrm{mv}$. Esta faixa de potencial redox é anóxica devida à presença de nitrito afluente. É importante salientar que os quimiostatos se mantiveram sempre com concentração de oxigênio dissolvido igual a zero, mantendo condições favoráveis à anammox.

\subsubsection{REMOÇÃO DO NITROGÊNIO AMONIACAL}

A concentração afluente de amônia se mostrou bastante variável na etapa I, principalmente até o dia 91 de operação (seta na Figura 5.11). No entanto, constata-se que mesmo com a oscilação na concentração afluente, tanto em Q1 quanto Q2, mantiveram-se com as mesmas eficiências de remoção.

O quimiostato Q2 apesar de ter menor concentração inicial de biomassa (2,06gSTV/L) apresentou remoção média ligeiramente maior que Q1 (6,22gSTV/L), na 


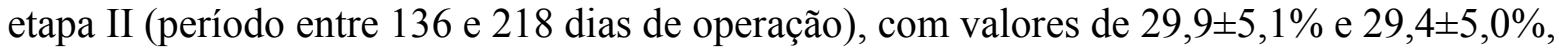
respectivamente, para concentração afluente média de $65,9 \mathrm{mg} \mathrm{N}-\mathrm{NH}_{4}{ }^{+} / \mathrm{L}$. Neste período os quimiostatos operaram com estabilidade.

$\mathrm{Na}$ etapa III (entre os dias 219 e 232), os quimiostatos foram alimentados com afluente contendo somente nitrogênio amoniacal para verificar se a remoção que estava ocorrendo era devido ao stripping da amônia livre. A remoção de nitrogênio, durante esse período, em Q1 variou de 3,7 a 11,7mg N-NH${ }_{4}{ }^{+} / \mathrm{L}$, e em Q2 a faixa de remoção foi entre 4,5 e $10,5 \mathrm{mg} \mathrm{N}-\mathrm{NH}_{4}{ }^{+} / \mathrm{L}$, para concentração afluente média de $67,1 \mathrm{mg} \mathrm{N}-\mathrm{NH}_{4}{ }^{+} / \mathrm{L}$. Em ambos os casos a remoção foi aquém da observada anteriormente.

A remoção do $\mathrm{N}^{-\mathrm{NH}_{4}}{ }^{+}$foi de origem biológica, uma vez que, em pH igual a 8 e $37^{\circ} \mathrm{C}$ (condições de operação nos quimiostatos), a concentração teórica máxima possível de amônia livre $\left(\mathrm{N}-\mathrm{NH}_{3}\right)$ é de $6,31 \mathrm{mg} / \mathrm{L}$. Esse valor está na faixa de remoção observada quando os quimiostatos foram alimentados somente com amônia, portanto o stripping da amônia foi descartado como principal processo de remoção.

$\mathrm{Na}$ etapa IV, principalmente entre os dias 236 e 247, além dos quimiostatos se recuperarem da ausência de nitrito afluente, começou a ocorrer nitrificação nas mangueiras de alimentação. Esse fato se observou a partir do dia 243, quando constatou-se nitrato afluente nos quimiostatos. Nesse período, as concentrações de nitrito afluente estiveram elevadas, alcançando valores de até a $111,9 \mathrm{mg} \mathrm{N}-\mathrm{NO}_{2}{ }^{-} / \mathrm{L}$.

Nos dias 243 e 247 as concentrações dos compostos nitrogenados foram analisadas em amostras coletadas do frasco de alimentação e na entrada dos quimiostatos demonstrando que o processo de nitrificação realmente estava ocorrendo.

Na Tabela 5.2 estão expostos os valores do nitrogênio nitrificado calculados de duas maneiras: (1) pela redução da concentração da amônia na entrada em relação ao frasco, e (2) pelo aumento do nitrito na entrada em relação ao frasco somado ao nitrato na entrada do quimiostato. Os valores foram muito próximos indicando que, realmente, estava ocorrendo nitrificação. Para solucionar o problema trocou-se a mangueira de silicone por mangueiras de PVC flexível impermeável à atmosfera.

Na etapa V de operação (entre os dias 274 e 296) verificou-se, novamente, estabilidade do processo. No entanto, ocorreu inversão das eficiências de remoção da amônia. O quimiostato Q1 apresentou maior eficiência de remoção de $\mathrm{N}_{-} \mathrm{NH}_{4}{ }^{+}$que Q2, com valores, respectivamente de $51,6 \pm 13,1 \%$ e $39,3 \pm 14,4 \%$, para concentração afluente média de $80 \mathrm{mg} \mathrm{N}^{-\mathrm{NH}_{4}}{ }^{+} / \mathrm{L}$. Todos os valores das concentrações de amônia afluente e efluente Q1 e Q2 durante o período de operação estão na Tabela 1 (Anexo). 
Tabela 5.2. Análises dos compostos nitrogenados no frasco de alimentação e no afluente dos quimiostatos.

\begin{tabular}{|c|c|c|c|c|c|c|c|c|}
\hline \multirow[t]{2}{*}{$\begin{array}{l}\text { Operação } \\
\text { (dias) }\end{array}$} & \multicolumn{3}{|c|}{$\begin{array}{c}\text { Frasco de } \\
\text { alimentação }\end{array}$} & \multicolumn{3}{|c|}{$\begin{array}{l}\text { Afluente dos } \\
\text { quimiostatos }\end{array}$} & \multirow{2}{*}{$\begin{array}{l}\text { Nitrogênio } \\
\text { nitrificado } \\
\text { (diminuição } \\
\text { da amônia) } \\
(\mathrm{mg} / \mathrm{L})\end{array}$} & \multirow{2}{*}{$\begin{array}{l}\text { Nitrogênio } \\
\text { nitrificado } \\
\text { (aumento } \\
\text { do nitrito } \\
\text { + nitrato) } \\
\text { (mg/L) }\end{array}$} \\
\hline & $\begin{array}{l}\mathrm{N}^{-\mathrm{NH}_{4}}{ }^{+} \\
(\mathrm{mg} / \mathrm{L})\end{array}$ & $\begin{array}{r}\mathrm{N}^{-\mathrm{NO}_{2}}{ }^{-} \\
(\mathrm{mg} / \mathrm{L})\end{array}$ & $\begin{array}{l}{\mathrm{N}-\mathrm{NO}_{3}}^{-} \\
(\mathrm{mg} / \mathrm{L})\end{array}$ & $\begin{array}{l}\mathrm{N}^{-\mathrm{NH}_{4}}{ }^{+} \\
(\mathrm{mg} / \mathrm{L})\end{array}$ & $\begin{array}{l}\mathrm{N}^{-\mathrm{NO}_{2}}{ }^{-} \\
(\mathrm{mg} / \mathrm{L})\end{array}$ & $\begin{array}{l}\mathrm{N}^{-\mathrm{NO}_{3}}{ }^{-} \\
(\mathrm{mg} / \mathrm{L})\end{array}$ & & \\
\hline 243 & 95,4 & 78,8 & 0 & 67,3 & 105,1 & 6,1 & 22,72 & 32,4 \\
\hline 247 & 83,02 & 68,48 & 0 & 27,4 & 111,9 & 11,63 & 55,6 & 55,05 \\
\hline $252 *$ & 89,54 & 75,14 & 0 & 85,59 & 75,05 & 0 & 3,95 & 0,09 \\
\hline
\end{tabular}

* analisado após troca das mangueiras, não se verificando mais nitrificação.

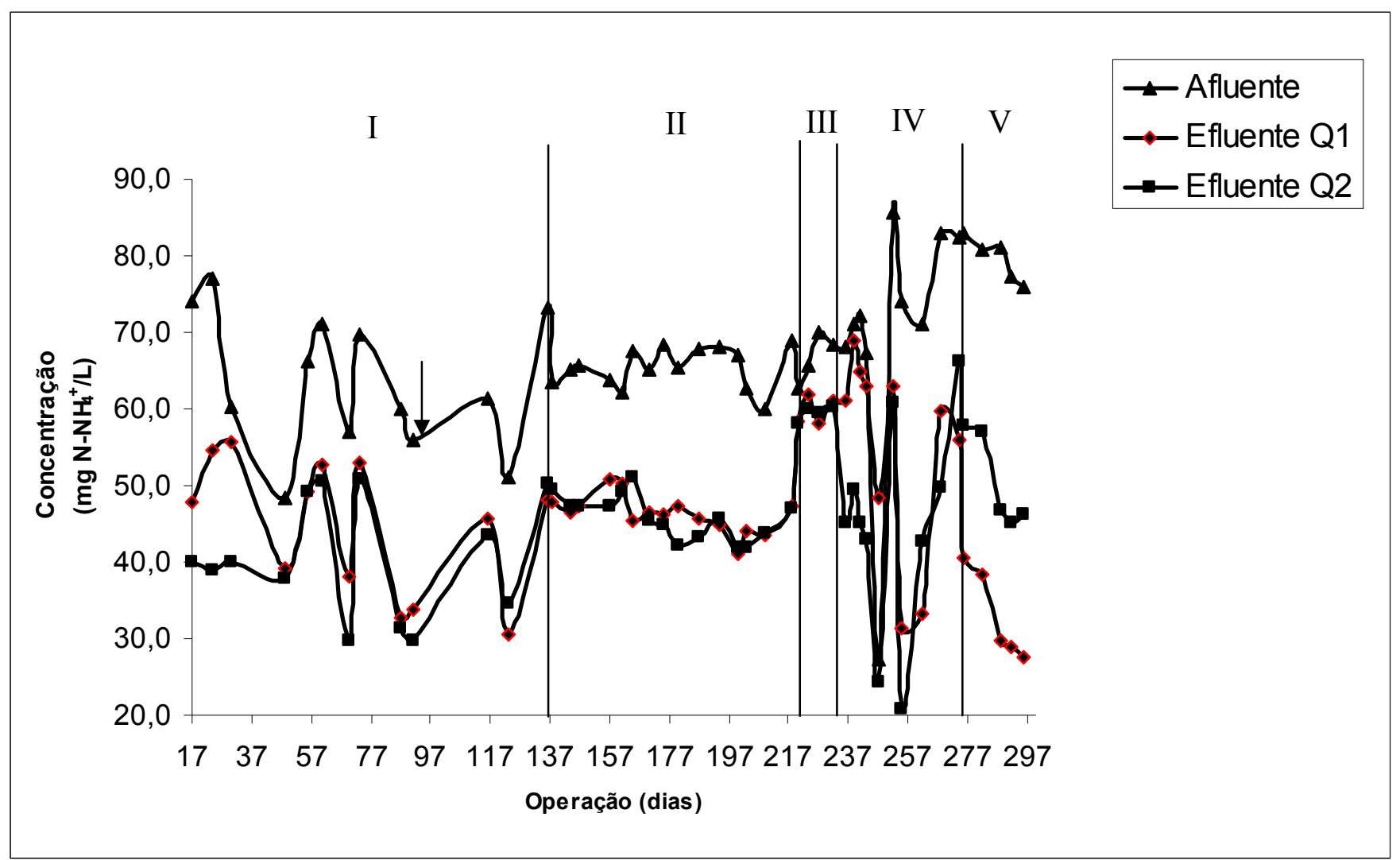

Figura 5.11. Variação temporal da concentração de nitrogênio na forma de amônia afluente e efluente em Q1 e Q2.

Após 120 dias de operação, a biomassa presente em Q1 mostrou-se granulada (Figura 5.12). Porém os grânulos apresentaram estrutura frágil e de fácil rompimento. No mesmo período a biomassa de Q2 apresentou-se floculenta. 


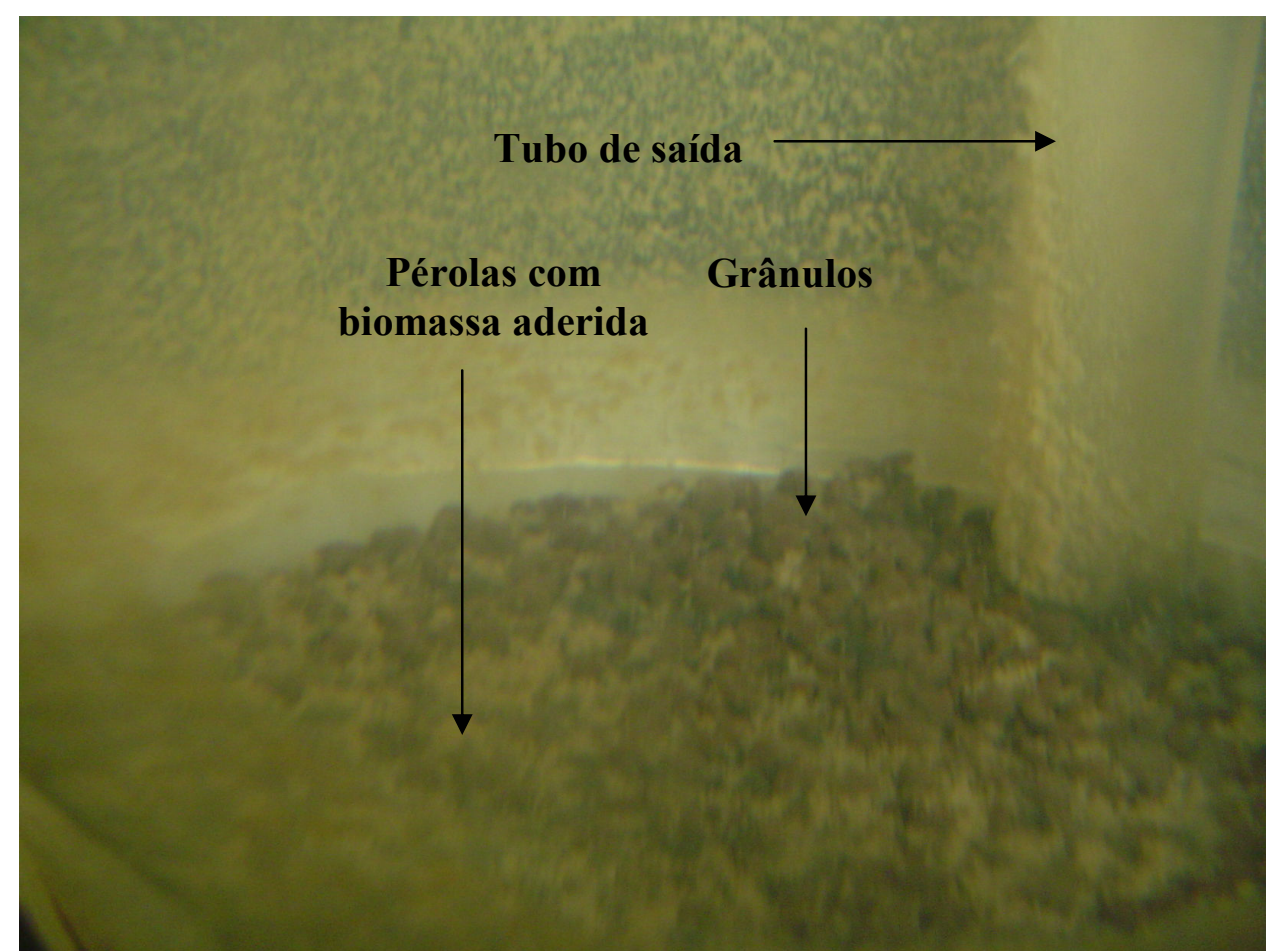

Figura 5.12. Foto da parte inferior de Q1 mostrando pérolas imobilizadas, grânulos de biomassa e tubo de saída.

\subsubsection{REMOÇÃO DO NITROGÊNIO NA FORMA DE NITRITO E PRODUÇÃO DE NITRATO}

Inicialmente, a concentração de nitrito efluente de Q1 era menor que afluente, provavelmente devido à desnitrificação endógena em função do meio de cultivo utilizado na alimentação ser autotrófico. Portanto, células morreram e serviram como fonte de carbono para este processo. Em Q2 este processo de desnitrificação endógena foi mais rápido provavelmente devido à menor concentração de biomassa inicial; ou seja, 2,06mg STV/L em Q2 em relação a 6,22mg STV/L em Q1.

A partir do $48^{\circ}$ dia a análise das concentrações de nitrito indicou valores não esperados. Os valores na concentração efluente eram maiores que no afluente (Tabela 2 do Anexo). Então, se postulou que estivesse ocorrendo nitrificação. No entanto, argônio $(100 \%)$ era fluxionado nos quimiostatos e a concentração de oxigênio dissolvido analisada sempre foi zero.

Então, a partir do $85^{\circ}$ dia, além de deixar borbulhando argônio o tempo todo, ao frasco de alimentação foi fixado um balão preenchido com Hélio para evitar a formação de vácuo dentro do frasco e manter o meio no frasco anóxico. Até então o frasco estava em contato com a atmosfera através de tampão de algodão para se evitar a contaminação pelo 
ar.

A hipótese da nitrificação foi descartada, e as concentrações efluentes ainda se mantiveram maiores. Então a partir do $136^{\circ}$ dia, as análises de nitrito e nitrato começaram a ser realizadas por análise de injeção em fluxo (FIA), e os valores encontrados foram menores que o do afluente.

Entre os dias 136 e 218 (etapa II), os quimiostatos se mantiveram estáveis (Figura 5.13) e com remoções de $\mathrm{N}^{-\mathrm{NO}_{2}}{ }^{-}$de $70,5 \pm 14,9 \%$ e $70 \pm 15,7 \%$ em Q1 e Q2 respectivamente, para concentrações afluentes médias de 70,6mg $\mathrm{N}-\mathrm{NO}_{2}{ }^{-} / \mathrm{L}$. Durante este período as concentrações efluentes de nitrato em Q1 e Q2 estiveram sempre abaixo do limite de detecção, ou seja, abaixo de $0,5 \mathrm{mgN}-\mathrm{NO}_{3}{ }^{-} / \mathrm{L}$.

Entre os dias 219 e 232 (etapa III), os quimiostatos foram alimentados sem nitrito. O nitrito efluente analisado em Q1 e Q2 nos dias 220 e 224 foram devido ao residual de alimentações anteriores ainda presentes nos quimiostatos. O TDH em ambos quimiostatos calculado foi de 3,6 dias, considerando-se a vazão analisada em $18 \mathrm{~mL} / \mathrm{h}$ e volume útil dos quimiostatos de 1,54L. 


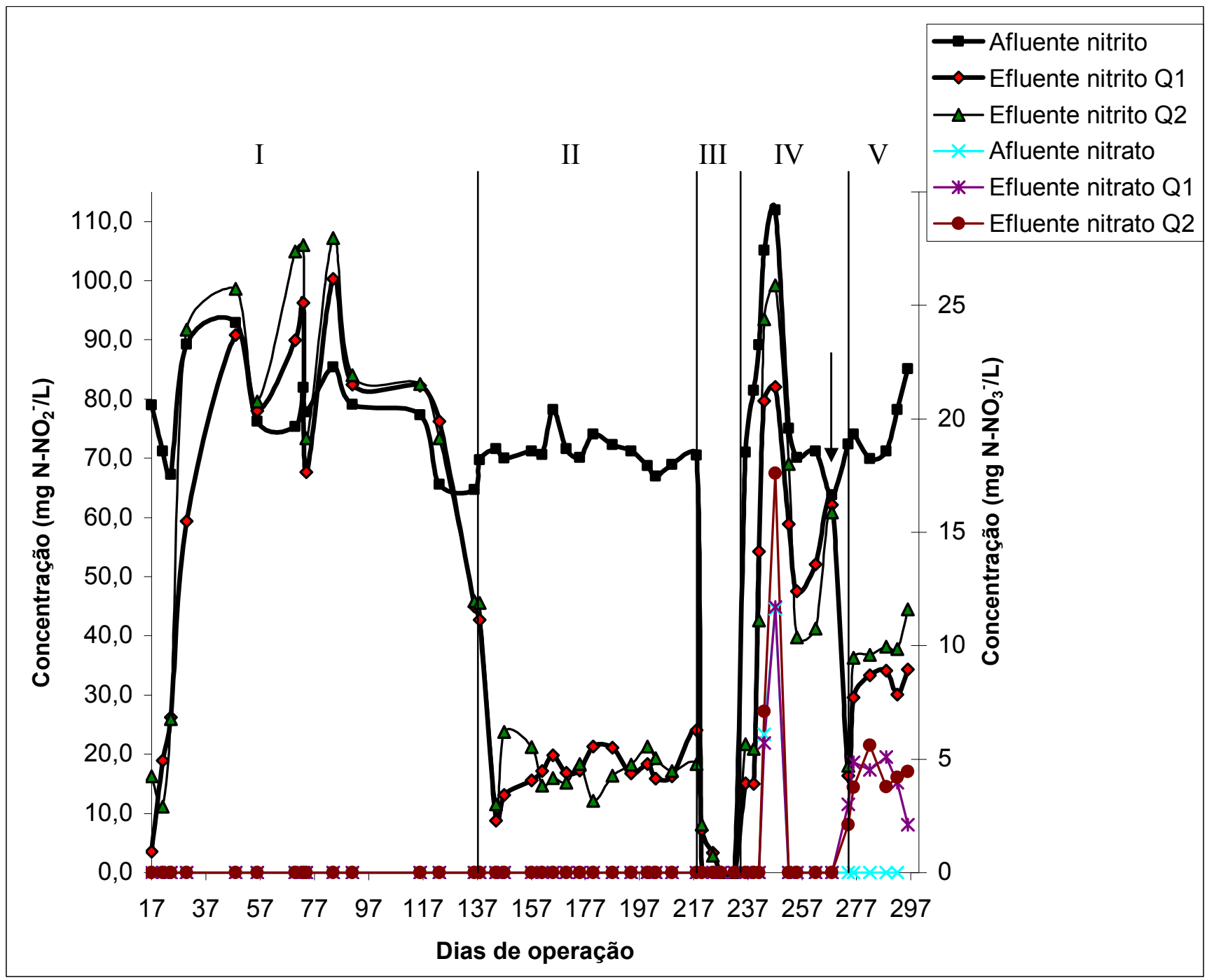

Figura 5.13. Variação temporal da concentração de nitrogênio na forma de nitrito e nitrato afluente e efluente em Q1 e Q2.

Após o período de nitrificação nas mangueiras e instabilidade (236-274 dias de operação), a estabilidade na remoção do nitrito voltou com 274 dias de operação (etapa V) com remoções médias de $60,5 \pm 9,2 \%$ e $53,2 \pm 10,9 \%$ para Q1 e Q2, respectivamente, com concentração afluente de $75,2 \mathrm{mg} \mathrm{N}-\mathrm{NO}_{2}{ }^{-} / \mathrm{L}$.

Os valores de remoção do nitrito na etapa V (274-296 dia) foram ligeiramente menores que os encontrados na etapa II (136-218 ${ }^{\circ}$ dia). No entanto, na etapa $V$, também foi detectada presença de nitrato no afluente de Q1 e Q2, em acordo com o processo anammox (Eq. 5).

$$
\begin{aligned}
1 \mathrm{NH}_{4}^{+}+1,32 \mathrm{NO}_{2}^{-}+0,066 \mathrm{HCO}_{3}^{-}+0,13 \mathrm{H}^{+} \longrightarrow & \longrightarrow \\
\longrightarrow & 1,02 \mathrm{~N}_{2}+0,26 \mathrm{NO}_{3}{ }^{-}+0,066 \mathrm{CH}_{2} \mathrm{O}_{0,5} \mathrm{~N}_{0,15}+2,03 \mathrm{H}_{2} \mathrm{O}
\end{aligned}
$$

No dia 268 (seta) não foi detectada remoção, provavelmente por que no dia 263 foi 
retirada biomassa dos quimiostatos para realização de ensaios em batelada, causando instabilidade (não verificada nas análises de amônia). Deve-se ainda ressaltar que a inibição pelo excesso de nitrito $\left(111,9 \mathrm{mg} \mathrm{N}^{-\mathrm{NO}_{2}}{ }^{-} / \mathrm{L}\right.$ no dia 247$)$ foi reversível aos consórcios presentes nos dois quimiostatos.

Os valores da proporção $\mathrm{N}-\mathrm{NH}_{4}{ }^{+}: \mathrm{N}^{-\mathrm{NO}_{2}}{ }^{-}$, a partir do $136^{\circ}$ dia, estão expostos na Tabela 5.3 Os valores encontrados por JIANLONG \& JING (2005) para estes parâmetros foram de 1:2,63, os quais sugerem que essa relação é devida a desnitrificação da matéria orgânica (dextrose) presente no meio de alimentação. Os valores encontrados, no período entre 136 e 296 dias de operação, estão relativamente próximos aos observados pelos autores $o p$. cit. No entanto, as condições de alimentação de Q1 e Q2 favoreceram processos autotróficos, diferentemente das condições heterotróficas dos pesquisadores op. cit. $\mathrm{O}$ processo anammox ocorreu em Q1 e Q2, concomitantemente a desnitrificação da matéria orgânica endógena remanescente da morte celular. 
Tabela 5.3. Quantidade removida de nitrogênio na forma dos compostos nitrogenados e proporção de remoção.

\begin{tabular}{|c|c|c|c|c|c|c|}
\hline \multirow{2}{*}{$\begin{array}{c}\text { Operação } \\
\text { (dias) } \\
\end{array}$} & \multicolumn{2}{|c|}{ Remoção Q1 } & \multirow{2}{*}{ 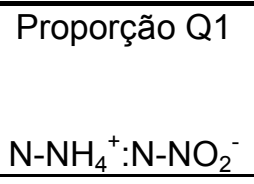 } & \multicolumn{2}{|c|}{ Remoção Q2 } & \multirow{2}{*}{$\begin{array}{l}\text { Proporção Q2 } \\
\mathrm{N}-\mathrm{NH}_{4}^{+}: \mathrm{N}-\mathrm{NO}_{2}\end{array}$} \\
\hline & $\begin{array}{c}\mathrm{mg} \mathrm{N}- \\
\mathrm{NH}_{4}^{+} / \mathrm{L} \\
\end{array}$ & $\begin{array}{l}\mathrm{mg} \mathrm{N}- \\
\mathrm{NO}_{2}^{-/} / \mathrm{L} \\
\end{array}$ & & $\begin{array}{c}\mathrm{mg} \mathrm{N}- \\
\mathrm{NH}_{4}^{+} / \mathrm{L} \\
\end{array}$ & $\begin{array}{l}\mathrm{mg} \mathrm{N}- \\
\mathrm{NO}_{2}^{-/} / \mathrm{L} \\
\end{array}$ & \\
\hline 136 & 24,96 & 19,73 & $1: 0,79$ & 22,84 & 18,78 & $1: 0,82$ \\
\hline 138 & 15,65 & 27,00 & $1: 1,72$ & 13,96 & 24,10 & $1: 1,73$ \\
\hline 144 & 18,61 & 62,83 & $1: 3,38$ & 17,77 & 60,12 & $1: 3,38$ \\
\hline 147 & 18,19 & 56,93 & $1: 3,13$ & 18,19 & 46,32 & $1: 2,55$ \\
\hline 157 & 13,1 & 55,6 & $1: 4,24$ & 16,5 & 50,0 & $1: 3,03$ \\
\hline 161 & 12,0 & 53,4 & $1: 4,45$ & 13 & 55,9 & $1: 4,30$ \\
\hline 165 & 22,2 & 58,4 & $1: 2,63$ & 16,3 & 62,2 & $1: 3,82$ \\
\hline 170 & 18,8 & 54,7 & $1: 2,91$ & 19,9 & 56,4 & $1: 2,83$ \\
\hline 175 & 22,2 & 52,8 & $1: 2,38$ & 23,6 & 51,8 & $1: 2,19$ \\
\hline 180 & 18,1 & 52,8 & $1: 2,92$ & 23,2 & 62,0 & $1: 2,67$ \\
\hline 187 & 22,2 & 51,2 & 2,31 & 24,6 & 55,9 & $1: 2,27$ \\
\hline 194 & 23,2 & 54,4 & $1: 2,34$ & 22,5 & 53,0 & $1: 2,35$ \\
\hline 200 & 25,8 & 50,4 & $1: 1,95$ & 25,2 & 47,4 & $1: 1,88$ \\
\hline 203 & 18,7 & 51,1 & $1: 2,73$ & 20,8 & 47,7 & $1: 2,29$ \\
\hline 209 & 16,5 & 52,6 & $1: 3,19$ & 16,4 & 51,7 & $1: 3,15$ \\
\hline 218 & 21,5 & 46,4 & $1: 2,16$ & 22 & 52,2 & $1: 2,37$ \\
\hline 220 & 4,3 & $-7,2$ & n.a. & 4,5 & $-8,1$ & n.a. \\
\hline 224 & 3,7 & $-3,4$ & n.a. & 5,8 & $-2,9$ & n.a. \\
\hline 227 & 11,7 & 0 & n.a. & 10,5 & 0,0 & n.a. \\
\hline 232 & 7,2 & 0 & n.a. & 8,1 & 0,0 & n.a. \\
\hline 236 & 7,2 & 55,9 & $1: 7,76$ & 23 & 49,3 & $1: 2,14$ \\
\hline 239 & 2,2 & 66,5 & $1: 30,23$ & 21,8 & 60,6 & $1: 2,78$ \\
\hline 241 & 7,4 & 34,95 & $1: 4,72$ & 26,9 & 46,6 & $1: 1,73$ \\
\hline 243 & 4,2 & 25,36 & $1: 6,04$ & 24,3 & 11,6 & $1: 0,48$ \\
\hline 247 & $-21,0$ & 29,82 & n.a. & 3,1 & 12,7 & $1: 4,10$ \\
\hline 252 & 22,7 & 16,17 & $1: 0,71$ & 24,7 & 5,9 & $1: 0,24$ \\
\hline 255 & 43,0 & 22,59 & $1: 0,53$ & 53,4 & 30,4 & $1: 0,57$ \\
\hline 262 & 37,8 & 19,1 & $1: 0,51$ & 28,3 & 30,0 & $1: 1,06$ \\
\hline 268 & 23,3 & 1,76 & $1: 0,08$ & 33,1 & 3,0 & $1: 0,09$ \\
\hline 274 & 26,6 & 56,01 & $1: 2,10$ & 16,26 & 54,3 & $1: 3,34$ \\
\hline 276 & 42,3 & 44,54 & $1: 1,05$ & 25,09 & 37,8 & $1: 1,51$ \\
\hline 282 & 42,2 & 36,52 & $1: 0,87$ & 23,58 & 33,1 & $1: 1,41$ \\
\hline 288 & 51,3 & 37,1 & $1: 0,72$ & 34,3 & 33,0 & $1: 0,96$ \\
\hline 292 & 48,4 & 48,1 & $1: 0,99$ & 32,2 & 40,4 & $1: 1,26$ \\
\hline 296 & 48,3 & 50,75 & $1: 1,05$ & 29,62 & 40,6 & $1: 1,37$ \\
\hline
\end{tabular}

n.a. não aplicável devido à ausência de nitrito afluente

A proporção entre a amônia e nitrito removido e nitrato gerado está exposto na Tabela 5.4 mostrando relativa similaridade com a equação estequiométrica da anammox, principalmente após o dia 276. A Tabela 5.5 mostra os parâmetros estequiométricos 
encontrados em alguns reatores anammox, mostrando que os valores encontrados neste trabalho estão em acordo com a literatura.

Tabela 5.4. Parâmetros estequiométricos de amônia e nitrito removidos e nitrato gerado, a partir do $274^{\circ}$ dia de operação.

\begin{tabular}{ccc}
\hline $\begin{array}{c}\text { Operação } \\
\text { (dias) }\end{array}$ & $\mathrm{N}^{-\mathrm{NH}_{4}}{ }_{4}^{+}: \mathrm{N}_{-} \mathrm{NO}_{2}{ }^{-}: \mathrm{N}_{-} \mathrm{NO}_{3}{ }^{-}$ & $\mathrm{N}^{-\mathrm{NH}_{4}}{ }^{+}: \mathrm{N}_{-} \mathrm{NO}_{2}{ }^{-}: \mathrm{N}-\mathrm{NO}_{3}{ }^{-}$ \\
\hline 274 & $1: 2,10: 0,11$ & $1: 3,34: 0,13$ \\
276 & $1: 1,05: 0,12$ & $1: 1,51: 0,15$ \\
282 & $1: 0,87: 0,11$ & $1: 1,41: 0,24$ \\
288 & $1: 0,72: 0,10$ & $1: 0,96: 0,11$ \\
292 & $1: 0,99: 0,08$ & $1: 1,26: 0,13$ \\
296 & $1: 1,05: 0,04$ & $1: 1,37: 0,15$ \\
\hline
\end{tabular}

Tabela 5.5. Comparação entre parâmetros estequiométricos encontrados na literatura e desta pesquisa.

\begin{tabular}{cc}
\hline Referência & ${\mathrm{N}-\mathrm{NH}_{4}{ }^{+}: \mathrm{N}_{2}: \mathrm{N}^{-} \mathrm{NO}_{3}{ }^{-}}^{\text {STROUS } \text { et al. (1998) }}$ \\
& $1: 1,3: 0,26$ \\
DAPENA-MORA et al. (2004)Reator gas-lift & $1: 1,28: 0,26$ \\
TOH et. al. (2002) & $1: 1: 0$ \\
& \\
DAPENA-MORA et al. (2004) Reator em batelada & $1: 1,11: 0,2$ \\
Quimiostato Q1 & $1: 1,13: 0,1$ \\
Quimiostato Q2 & $1: 1,64: 0,1$ \\
\hline
\end{tabular}

REGINATTO et. al. (2005,) operando reator seqüencial em batelada alimentado com concentrações afluentes próximas às desta pesquisa, obtiveram no final da operação, eficiência de remoção de nitrogênio total em torno de $40 \%$ com carga nitrogenada total aplicada de $40 \mathrm{mg} \mathrm{N} / \mathrm{L}_{\text {reator }}$ dia. Na etapa V Q1 obteve eficiência de remoção de nitrogênio total de $57,1 \pm 4,1 \%$ para carga nitrogenada total aplicada de $43,5 \pm 1,0 \mathrm{mg} \mathrm{N}\left(\mathrm{N}_{-} \mathrm{NO}_{2}{ }^{-}+\mathrm{N}-\right.$

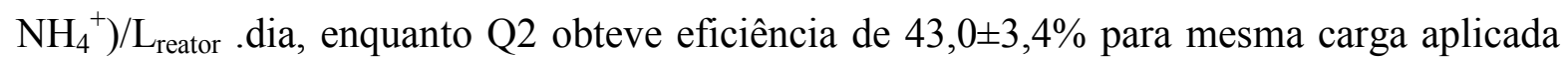
(Tabelas 5.6 e 5.7).

TOH et. al. (2002), avaliaram reator de leito fixo, com carga nitrogenada total aplicada próxima de $200 \mathrm{mg} \mathrm{N} / \mathrm{L}_{\text {reator }}$ dia e obtiveram carga nitrogenada total removida de $118 \mathrm{mg} \mathrm{N} / \mathrm{L}_{\text {reator }}$.dia, após 243 dias de operação. A eficiência de remoção foi de aproximadamente 58\%; ou seja, próxima à eficiência de Q1 (57,1\%) (Tabela 5.6). No entanto, a carga nitrogenada total removida pelos pesquisadores op. cit. foi maior devida a maior carga nitrogenada total aplicada. 
Em Q1 a carga nitrogenada (amônia) removida foi maior na etapa V $(12,1 \pm 2,5 \mathrm{mg} \mathrm{N}$ $\mathrm{NH}_{4}{ }^{+} / \mathrm{L}_{\text {reator }}{ }^{*}$ dia) em relação a etapa II $\left(5,5 \pm 1,1 \mathrm{mg} \mathrm{N}-\mathrm{NH}_{4}{ }^{+} / \mathrm{L}_{\text {reator }}{ }^{*}\right.$ dia $)$, como mostra a Tabela 5.6. Em Q2 também foi observado aumento na carga nitrogenada (amônia) removida na etapa $\mathrm{V}\left(7,5 \pm 1,9 \mathrm{mg} \mathrm{N}-\mathrm{NH}_{4}{ }^{+} / \mathrm{L}_{\text {reator }}{ }^{*}\right.$ dia $)$ em relação à etapa II $(5,6 \pm 1,1 \mathrm{mg} \mathrm{N}$ $\mathrm{NH}_{4}{ }^{+} / \mathrm{L}_{\text {reator }}{ }^{*}$ dia) como mostra a Tabela 5.7 .

A carga nitrogenada (nitrito) removida em Q1 diminuiu na etapa V $(10,5 \pm 5,3 \mathrm{mg} \mathrm{N}$ $\mathrm{NO}_{2}{ }^{-} / \mathrm{L}_{\text {reator }}{ }^{*}$ dia $)$ em relação à etapa II $\left(14 \pm 3,1 \mathrm{mgN}-\mathrm{NO}_{2}{ }^{-} / \mathrm{L}_{\text {reator }}{ }^{*}\right.$ dia $)$. No quimiostato Q2 também foi observado este comportamento com diminuição da remoção de carga nitrogenada (nitrito) na etapa $\mathrm{V}\left(9,4 \pm 4,7 \mathrm{mg} \mathrm{N}-\mathrm{NO}_{2}{ }^{-} / \mathrm{L}_{\text {reator }}{ }^{*}\right.$ dia) em relação à etapa II $\left(13,9 \pm 3,4 \mathrm{mg} \mathrm{N}-\mathrm{NO}_{2}{ }^{-} / \mathrm{L}_{\text {reator }}{ }^{*}\right.$ dia), como mostram as Tabelas 5.6 e 5.7.

Apesar desta queda na remoção de nitrito em ambos quimiostatos, Q1 teve eficiência de remoção de nitrogênio total aumentada de 50,9\% na etapa II para $57,1 \%$ na etapa V. O quimiostato Q2 teve eficiência de remoção de nitrogênio total diminuída de $50,8 \%$ na etapa II para $43 \%$ na etapa V.

Em Q1, a carga nitrogenada total removida na etapa $\mathrm{V}$ foi maior que no primeiro período de estabilização (etapa II), atingindo valores de $24,9 \pm 2,2 \mathrm{mg} \mathrm{N} / \mathrm{L}_{\text {reator*dia. No }}$ entanto, Q2 obteve maior carga nitrogenada total removida na etapa II, com valor de

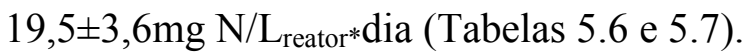

Os valores encontrados nesse trabalho não são comparáveis à maioria dos resultados de reatores anammox publicados na literatura, pois a maioria dos reatores anammox são operados com carga nitrogenada total aplicada de até $2,63 \mathrm{~g} \mathrm{~N} / \mathrm{L}_{\text {reator }}{ }^{*}$ dia (Jetten et. al., 1999) e com eficiências de remoção de até 95\% de nitrogênio total. No entanto, alguns destes reatores contêm biomassa adaptada às condições anammox por mais de três anos.

Talvez a configuração dos quimiostatos (com meio fresco gotejando na superfície e tubo coletor do efluente também na superfície) tenha limitado o contato do meio novo com a biomassa. Todavia, tal procedimento tem se mostrado eficiente no enriquecimento de consórcio microbiano apto às condições de oxidação anaeróbia da amônia; ou seja, meio com bicarbonato, amônia e nitrito em concentrações equimolares, calculadas em $5 \mathrm{mM}$ de cada composto, $\mathrm{pH}$ igual a 8 e temperatura de $37 \pm 1^{\circ} \mathrm{C}$. 


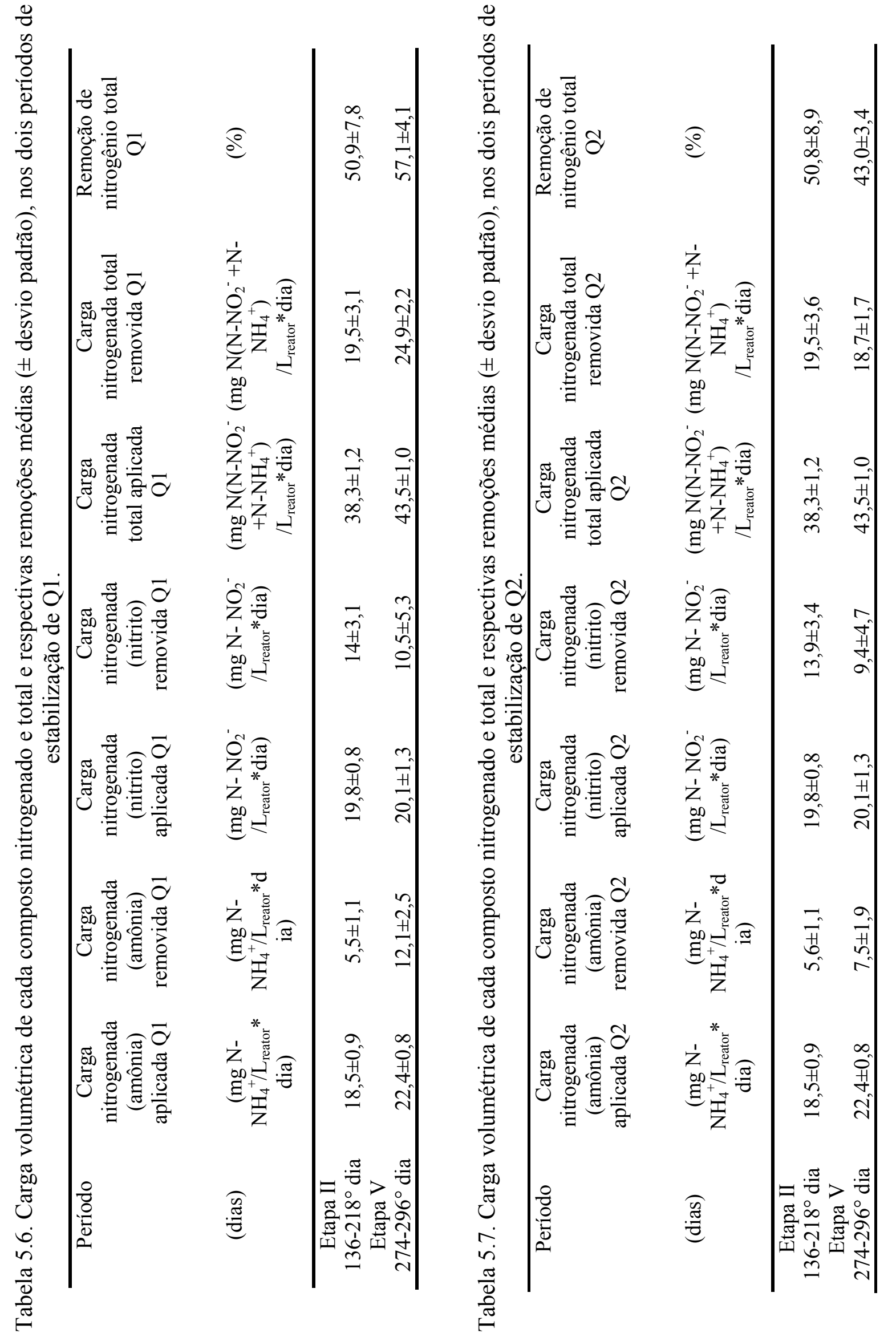




\subsection{HIBRIDAÇÃO IN SITU COM SONDAS FLUORESCENTES (FISH)}

A técnica do FISH confirmou a presença de organismos anammox nos consórcios enriquecidos nos dois quimiostatos. As Figuras 5.14 a 5.16 mostram fotomicrografias, do mesmo campo de visualização, em contraste de fase, epifluorescência com filtro WU (DAPI) e WG (sonda Cy3), da biomassa presente em Q1. A Figura 5.18 a 5.20 mostra fotomicrografias do consórcio enriquecido no quimiostato Q2, revelando resultados similares aos observados em Q1.

Nas Figuras 5.17 e 5.19, observa-se que as células coradas apresentaram-se aglomeradas, indicando que, possivelmente, sejam os mesmos aglomerados observados por microscopia de contraste de fase (Figuras 5.15. e 5.18.).

SCHMID et. al. (2003) utilizaram mesma sonda para caracterização de culturas anammox, e observaram morfologias semelhantes (aglomerados de cocos) coradas com a sonda. Desta forma, estes aglomerados de cocos corados com sonda Cy3 específica (Figuras 5.16 e 5.19) são células anammox com morfologia semelhante a observada por SCHMID et. al. (2003) e EGLI et. al. (2003).

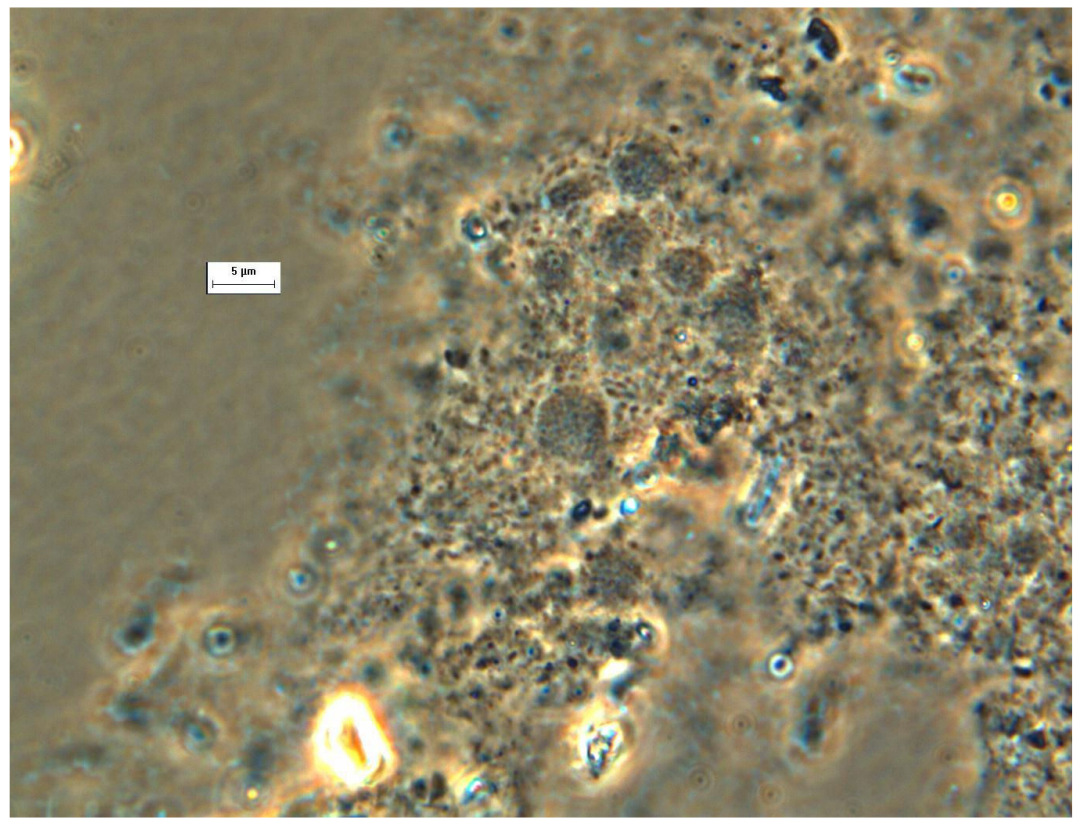

Figura 5.14. Microscopia de contraste de fase do consórcio enriquecido em Q1 após 312 dias de operação. 


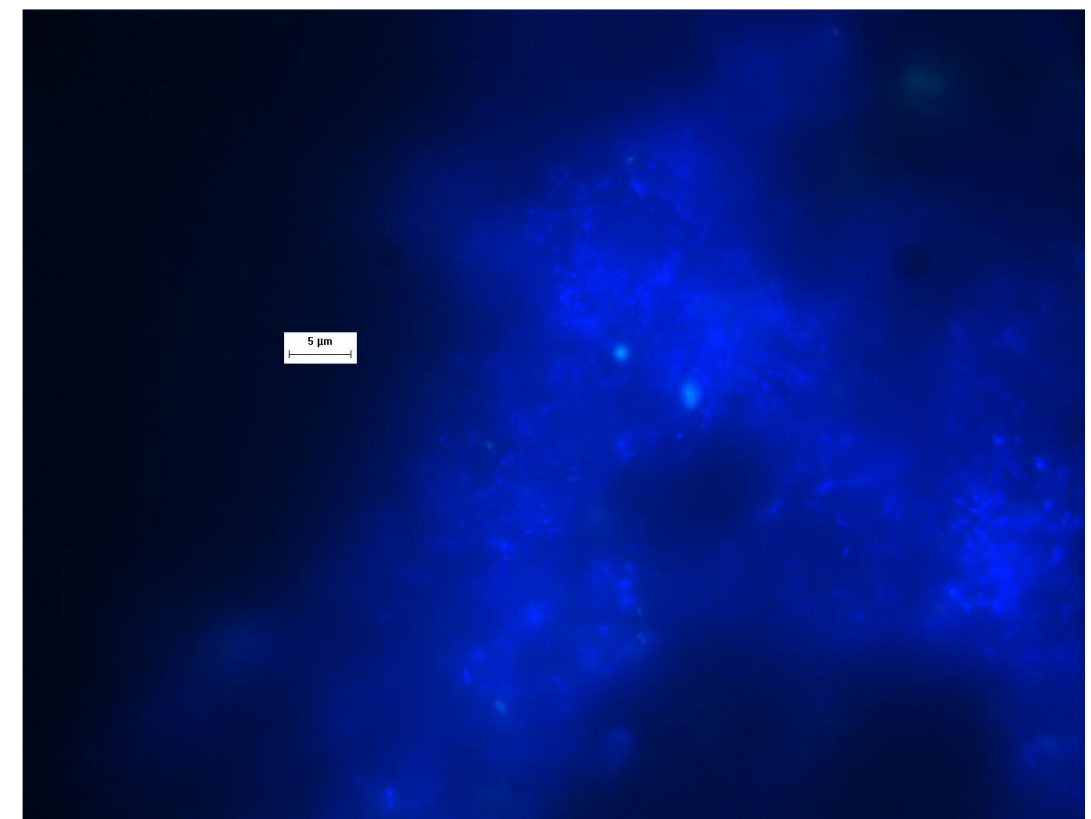

Figura 5.15. Microscopia de epifluorescência do consórcio enriquecido em Q1 após 312 dias de operação coradas com DAPI.

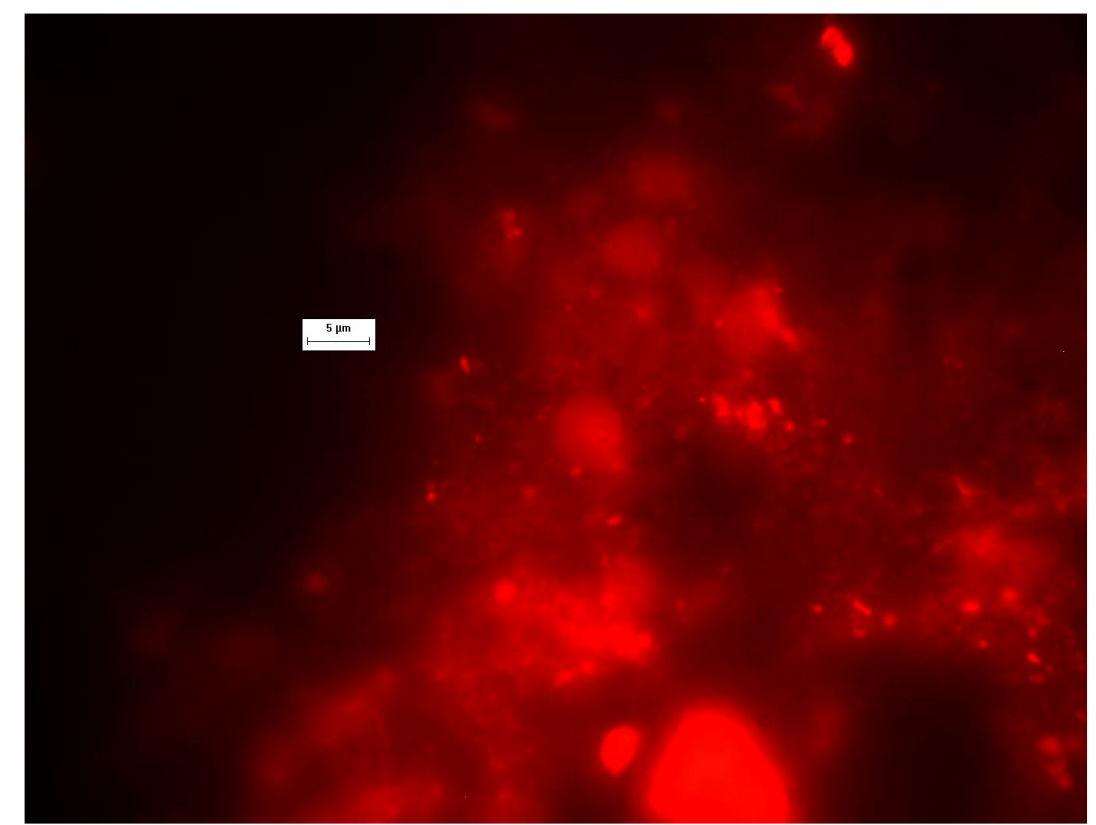

Figura 5.16. Microscopia de epifluorescência do consórcio enriquecido em Q1 após 312 dias de operação hibridadas com sonda AMX-368 CY3. 


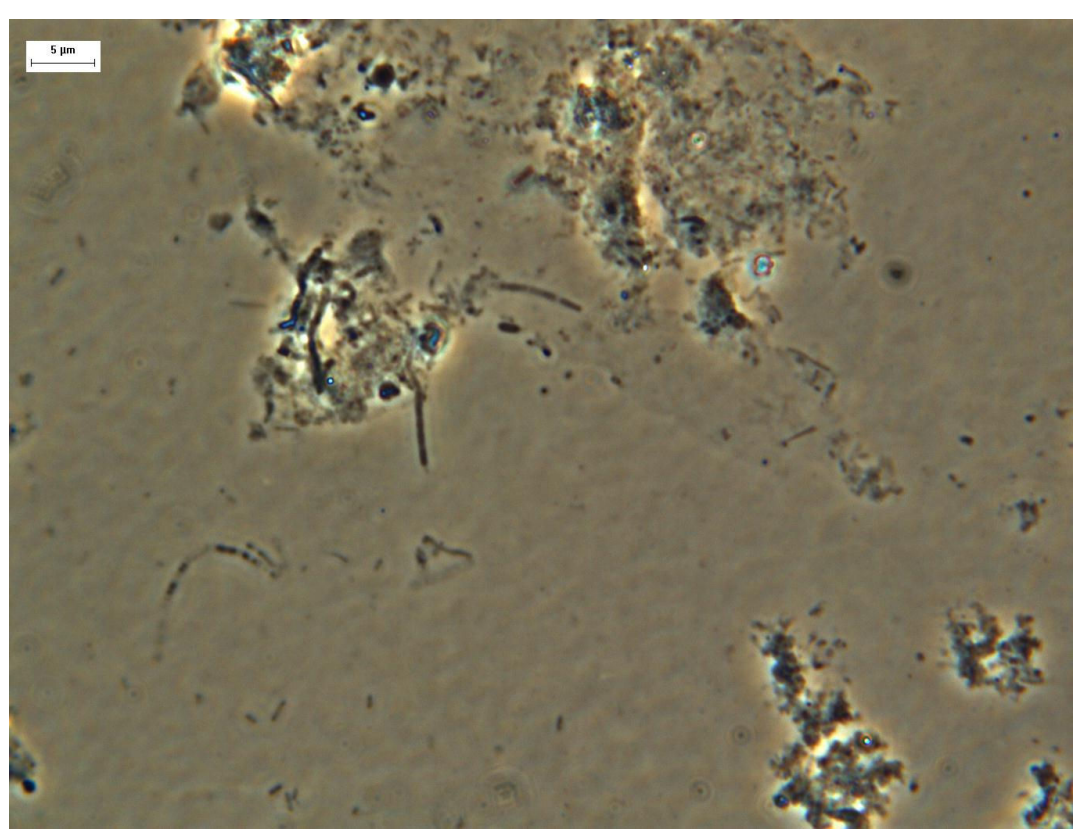

Figura 5.17. Microscopia de contraste de fase do consórcio enriquecido em Q2 após 312 dias de operação.

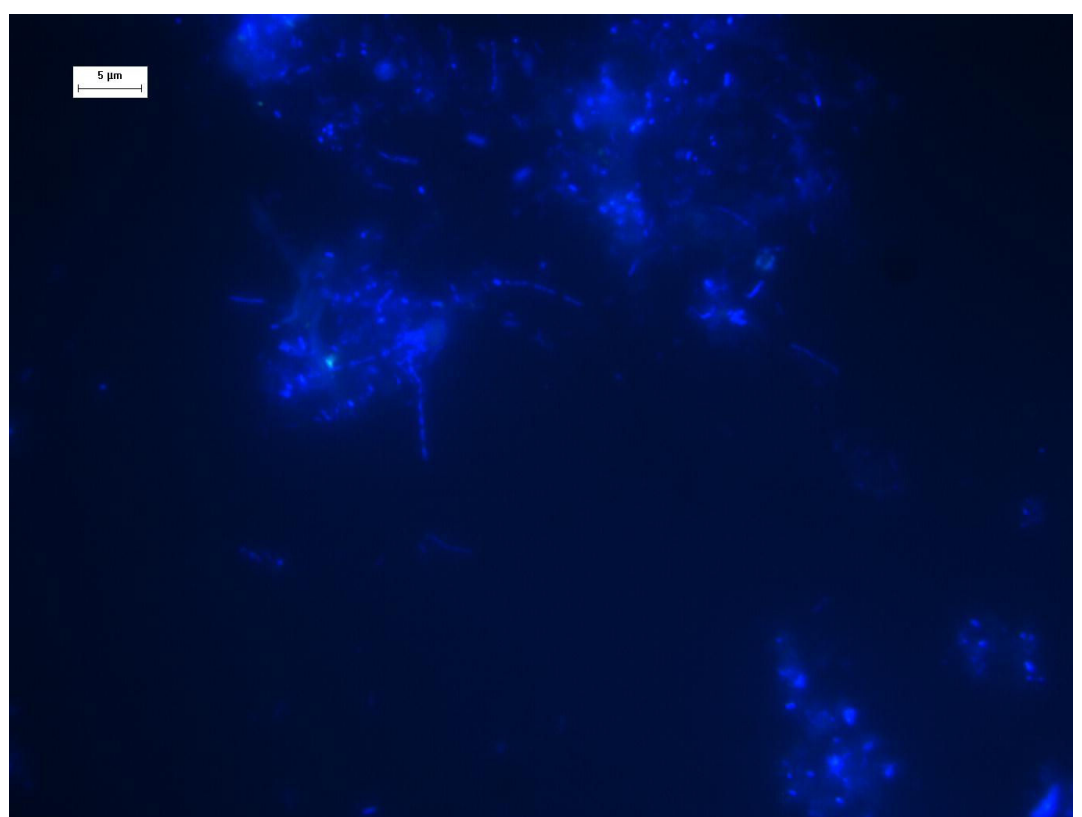

Figura 5.18. Microscopia de epifluorescência do consórcio enriquecido em Q2 após 312 dias de operação coradas com DAPI. 


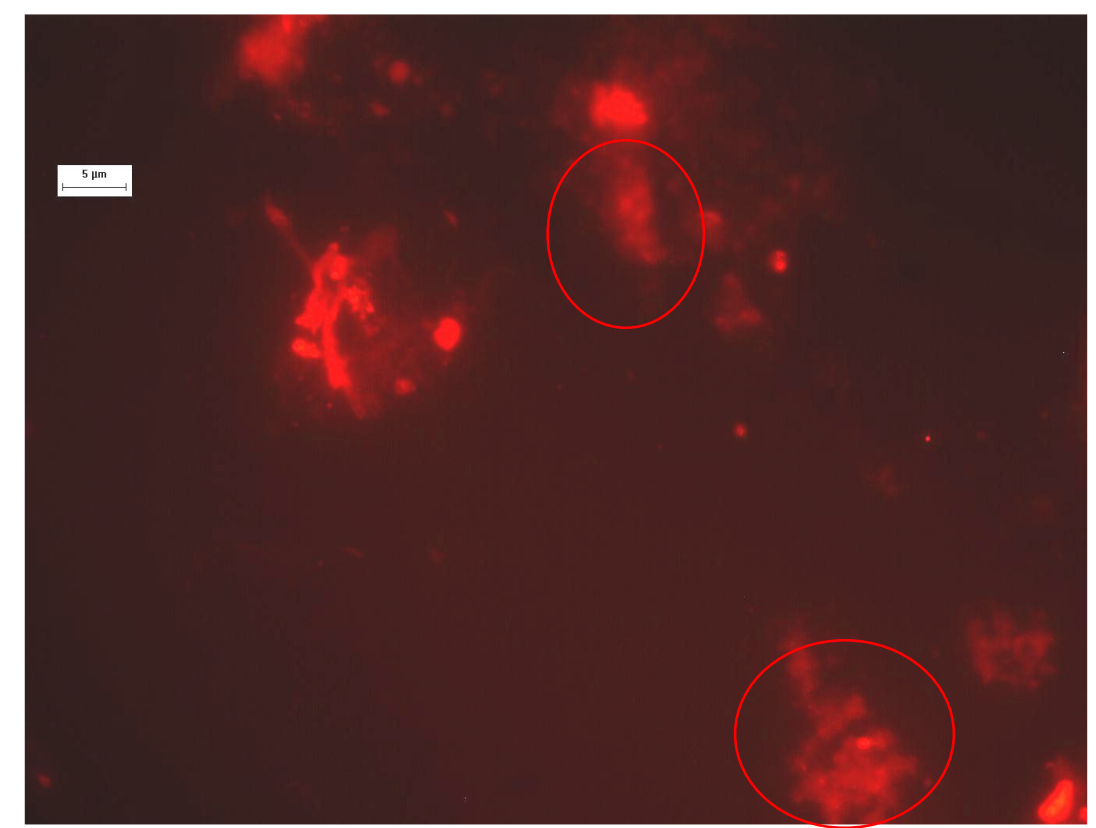

Figura 5.19. Microscopia de epifluorescência do consórcio enriquecido em Q2 após 312 dias de operação hibridadas com sonda AMX-368 CY3.

\subsection{ANÁLISE DA COMUNIDADE MICROBIANA}

A avaliação da estrutura da comunidade microbiana, presente em Q1 e Q2, em relação ao tempo de operação foi realizada por técnica de PCR/DGGE. Nesta análise cada banda foi considerada como pertencente a uma população microbiana.

A Figura 5.20 mostra o gel de DGGE do consórcio microbiano presente em Q1 em cada canaleta foi inserida alíquota de produto de PCR (primers 968FGC e1392R) em diferentes dias de operação.

As bandas 1 e 2 que aparecem no inóculo desapareceram após 143 dias de operação, indicando que, provavelmente, pertenciam a populações heterotróficas que necessitavam de matéria orgânica carbonácea em elevada concentração.

A banda 3 se manteve em Q1 somente até 197 dias de operação, e não foi observada com 143 dias de operação devido a falha no processo de extração de DNA, como pode ser observado na canaleta 2, a coloração com Brometo de etídeo foi pouco evidente.

As bandas 4 e 5 não observadas no inoculo são, provavelmente ligadas a populações relacionadas ao ciclo de nitrogênio favorecidas pelas condições de operação de Q1, assim como a banda 7 que se tornou muito evidenciada com 316 dias de operação.

A banda 6 foi primeiramente observada após a purificação com protocolo Percoll com 262 dias de operação, se manteve até 316 dias de operação, indicando estabelecimento no consórcio. Neste período de operação, provavelmente, a população anammox estava bem 
estabelecida conforme dados de operação do quimiostato Q1.

A banda 7 foi visualizada a partir de 197 dias, mas tornou-se muito evidente com 316 dias de operação de Q1, indicando estabelecimento desta população no consórcio microbiano.

As bandas que estão evidenciadas no inóculo, e em todos os períodos analisados, são pertencentes a populações de microrganismos aptos às condições presentes em nichos do reator UASB de abatedouro de aves, e as condições presentes em Q1.

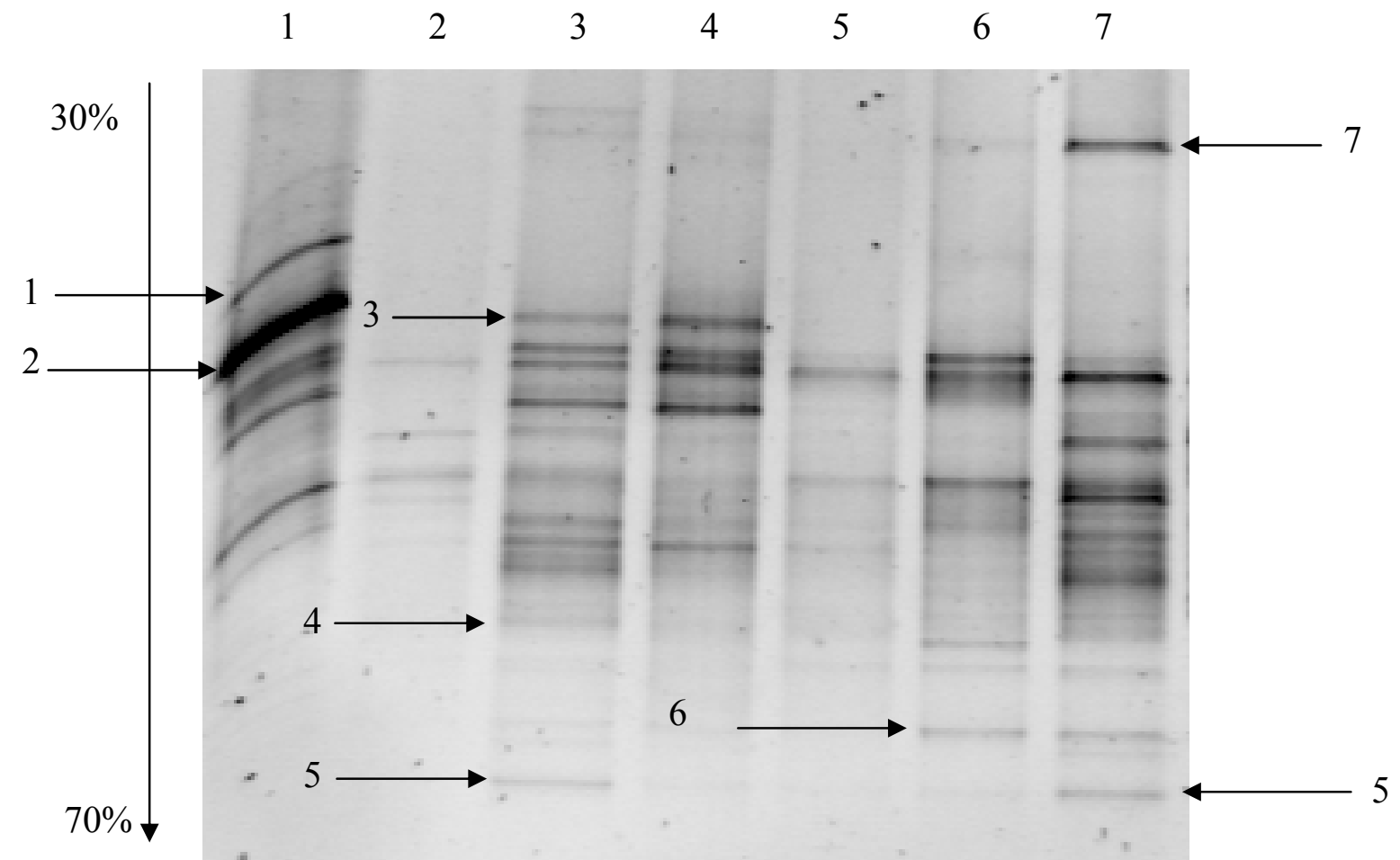

Figura 5.20. Fotografia da análise de DGGE de produtos de PCR com primers universais para Domínio Bacteria (968F-1392R) das amostras do Quimiostato Q1. Canaleta $1=$ inóculo, $2=143$ dias, $3=197$ dias, $4=197$ dias após purificação (Percoll), $5=262$ dias, $6=$ 262 dias após purificação (Percoll), 7316 dias.

A Figura 5.21 mostra o gel de DGGE do consórcio microbiano presente em Q2. Em cada canaleta foi inserida alíquota de produto de PCR (primers 968FGC e1392R) dos diferentes dias de operação.

O agrupamento de bandas 1 desapareceu com 143 dias de operação, indicando que essas bandas pertenciam a microrganismos selecionados negativamente, ou seja, excluídos do consórcio presente em Q2.

A banda 2 foi observada somente com 197 dias de operação (amostra sem purificar e purificada), indicando que esta população com baixa concentração de $\mathrm{G}+\mathrm{C}$ pode ter sido prejudicada pela elevada concentração de nitrito afluente entre os dias 236 e 247, sendo pouco evidente com 316 dias de operação. A banda 5 revelou população com 
comportamento similar ao da população presente na banda 2, no entanto esta população estava evidenciada no inóculo.

A banda 3 revelou população favorecida nas condições ambientais do quimiostato 2 , permanecendo até o final de operação, provavelmente estavam presentes no inóculo em baixa população e foram selecionadas. As populações presentes nas bandas 4 e 5 foram retiradas pelo processo de purificação conforme visualização nas canaletas 4 e 5 .

A banda 6 aparece muito evidenciada com 316 dias de operação estava presente desde o inóculo. Porém, pouco evidenciada com 197 dias de operação, esta banda está relacionada com microrganismos pertencentes ao grupo das bactérias verdes não-sulfurosas, como será discutido adiante.

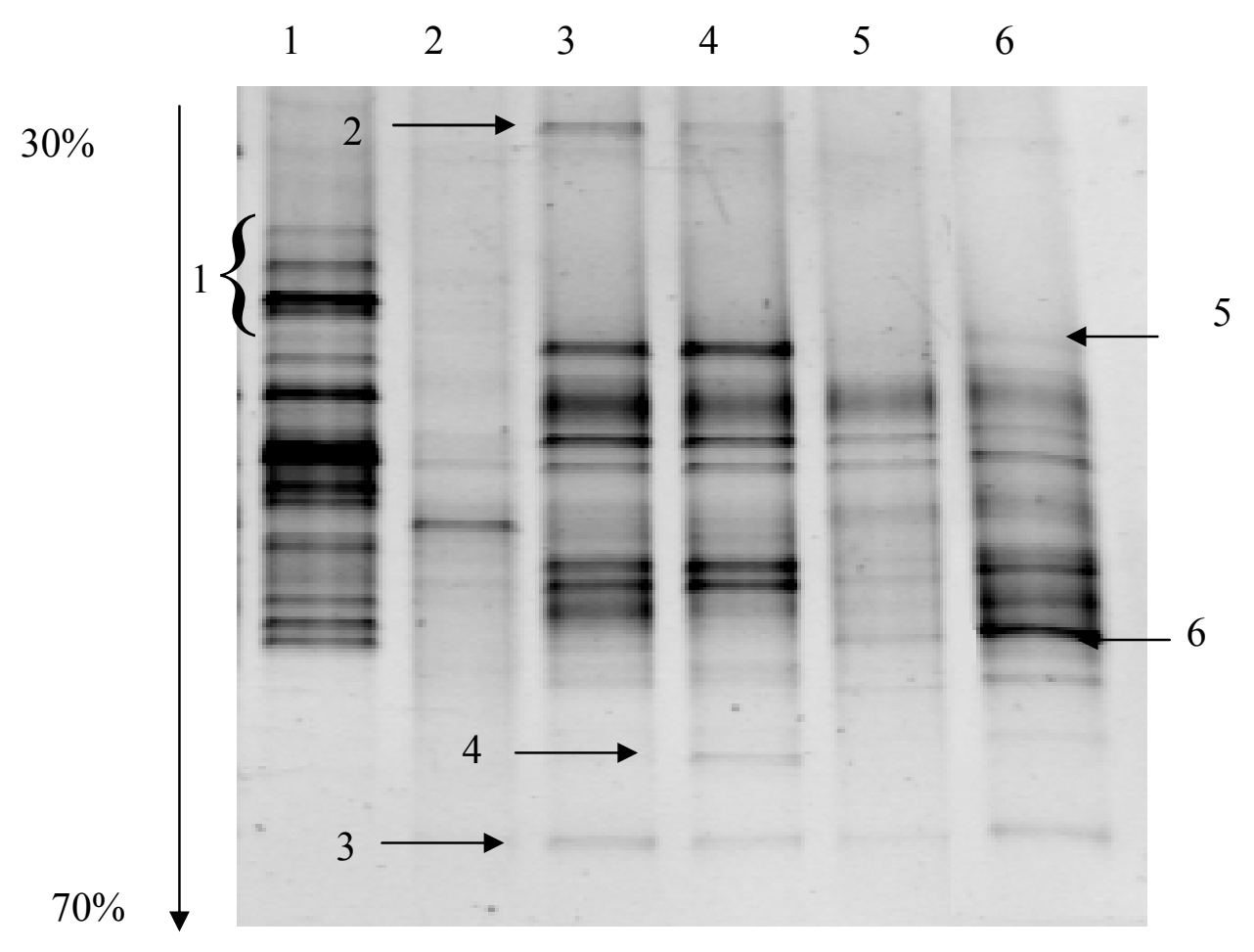

Figura 5.21. Fotografia da análise de DGGE de produtos de PCR com primers universais para Domínio Bacteria (968F-1392R) das amostras do Quimiostato Q2. Canaleta $1=$ inóculo, $2=143$ dias, $3=197$ dias, $4=197$ dias após purificação (Percoll), $5=262$ dias, $6=$ 316 dias.

\subsection{SEQÜENCIAMENTO DE BANDA E FILOGENIA}

Foram recortadas nove bandas do gel de DGGE, eluídas em água para recuperação do DNA, reamplificadas utilizando-se os primers 968F-1392R sem GC clamp e sequenciadas. As bandas recortadas estão nas Figuras 5.22 e 5.23. As seqüências obtidas 
foram verificadas e comparadas com banco de dados GenBank. As amostras com maior similaridade foram alinhadas e utilizadas para construção de árvore filogenética. A região do DNA ribossomal 16S amplificada situa-se entre as bases 968 e 1392 homólogas a posição em E. coli (Brosius et al. 1978).

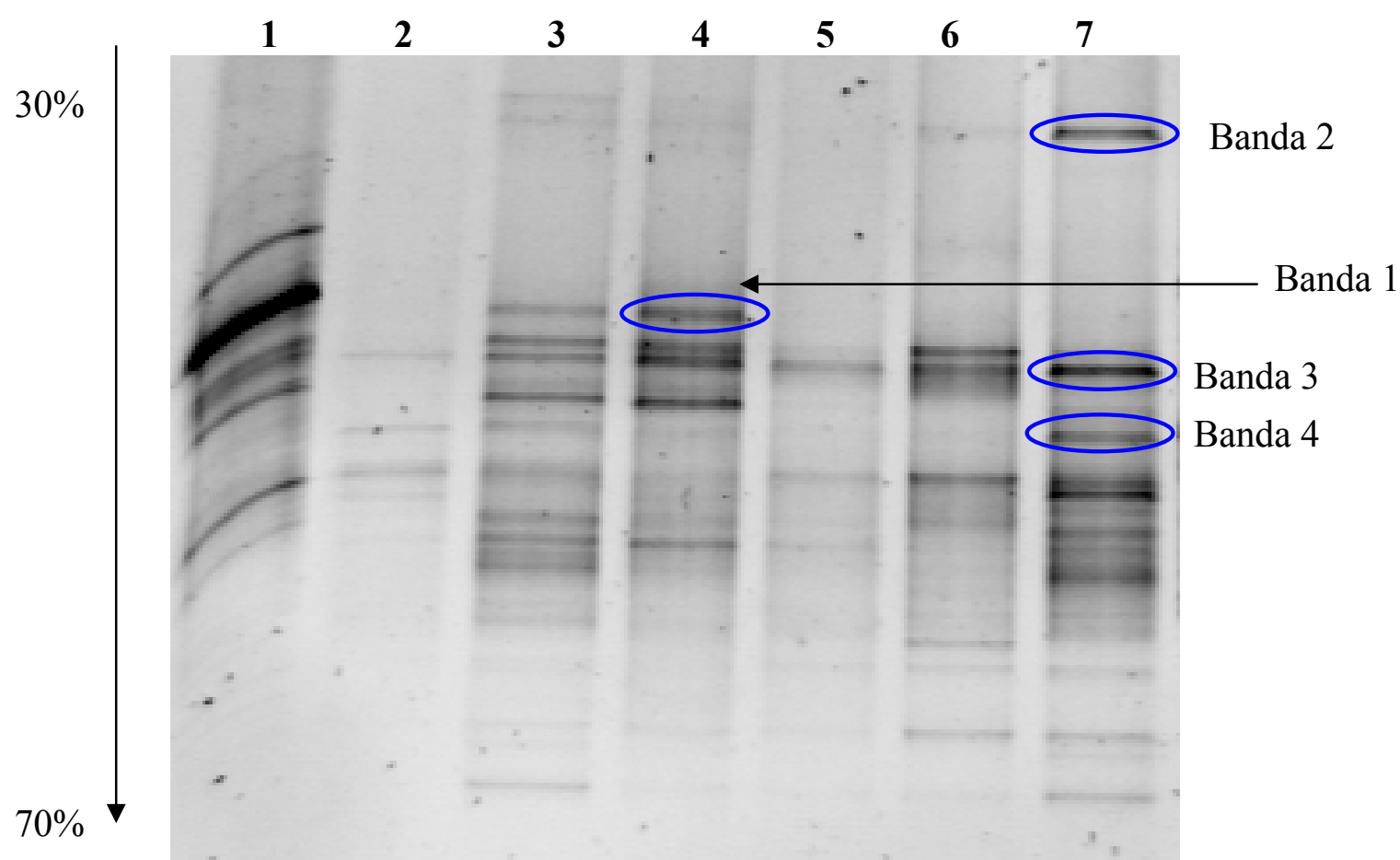

Figura 5.22. Fotografia da análise de DGGE de produtos de PCR com primers universais para Domínio Bacteria (968F-1392R) das amostras do Quimiostato Q1, com bandas retiradas para seqüênciamento. Canaleta $1=$ inóculo, $2=143$ dias, $3=197$ dias, $4=197$ dias após purificação (Percoll), $5=262$ dias, $6=262$ dias após purificação (Percoll), 7316 dias. 


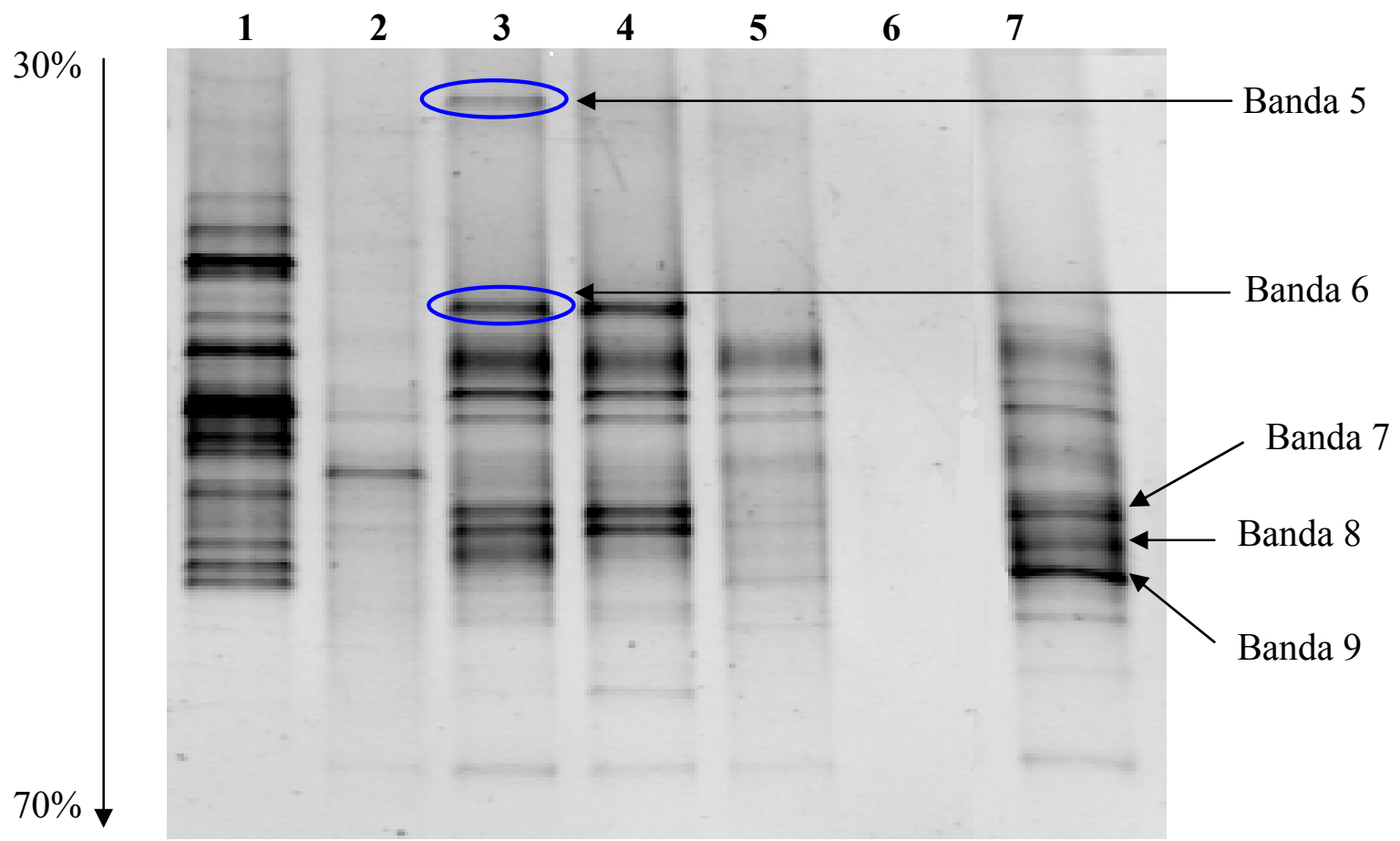

Figura 5.23. Fotografia da análise de DGGE de produtos de PCR com primers universais para Domínio Bacteria (968F-1392R) das amostras do Quimiostato Q2, com bandas retiradas para seqüênciamento. Canaleta $1=$ inóculo, $2=143$ dias, $3=197$ dias, $4=197$ dias após purificação (Percoll), $5=262$ dias, $6=262$ dias após purificação (Percoll), 7316 dias.

A análise filogenética, ainda, é a maneira mais eficiente de se estabelecer as relações entre diferentes organismos e não depende de similaridade, porém a busca por seqüências similares é o ponto de partida para análises filogenéticas.

O BLAST (Basic Local Alignment Search Tool) encontra regiões com similaridade entre duas seqüências. O programa compara seqüências de nucleotídeos com banco de dados e calcula o significado estatístico da comparação (e-value).

Na comparação com seqüências podem ocorrem "buracos" (gaps) entre dois pares de bases para ocorrer pareamento, por exemplo: a seqüência 1 (recorte da Banda 1) apresentou similaridade de 97\% com Criblamydia sequanensis. No entanto, quando as sequências foram observadas em árvore filogenética, as seqüências 1 a 6 e 8 não se relacionaram filogeneticamente com as clamídias e ficaram distantes dos demais grupos (àrvore não apresentada). Deve-se ressaltar que as seqüências oriundas das amostras 1,5 e 6 apresentaram similaridades elevadas com bactérias do grupo das clamídias.

As bactérias pertencentes ao grupo das clamídias são todas endoparasitas obrigatórias, sofrendo pressões seletivas diferentes de organismos de vida livre como os pertencentes em reatores biológicos. Além disso, apresentam evolução diferente, com tendência a perder pares de bases $(\mathrm{pb})$, mesmo em regiões conservadas como DNA 
ribossomal 16S. Portanto, não foram utilizadas na construção da árvore (BAPTESTE and GRIBALDO, 2003).

Além disso, a similaridade elevada não necessáriamente significa proximidade filogenética. As seqüências podem ser parecidas no entanto, pertencentes à regiões diferentes do DNAr 16S, portanto não homólogas e sem proximidade filogenética.

Depois de pronta árvore com esse padrão anormal, o alinhamento foi averiguado com maior rigor, e observou-se que essas amostras (1-6 e 8) não tinham alguns motivos (pequenas seqüências conservadas e, presentes em todos microrganismos do Domínio Bacteria), também verificou-se presença elevada de gaps.

Portanto, para construção da árvore filogenética descartou-se as seqüências 1 a 6 e 8 . A primeira árvore, efetivamente construída, utilizou as seqüências 7 e 9 (oriundas de Q2 com 316 dias de operação). As maiores similaridades obtidas do GenBank pelo BLAST relacionadas ao grupo das Bactérias verdes não-sulfurosas e alguns representantes de outros filos, tais como Planctomyces, Firmicutes, Bacterioidetes, Actinobactérias e Proteobacteria estão apresentadas na Figura 5.24. As seqüências 7 e 9 foram relacionadas filogeneticamente com amostras ambientais de bactérias verdes não-sulfurosas.

A seqüência 9 apresentou similaridade de 97\% com clones não cultiváveis SBR1029 e SBR1064 de reator sequencial em batelada usado na remoção de fósforo (Bond et al., 1995). A seqüência 7 apresentou $87 \%$ de similaridade com bactérias não cultiváveis ChloroflexiA11b, A30, H1 e H19, de lodo de reator nitrificante-desnitrificante (Juretschko et al., 2002), enquanto essas mesmas seqüências apresentaram similaridade de $97 \%$ com a amostra 9. 


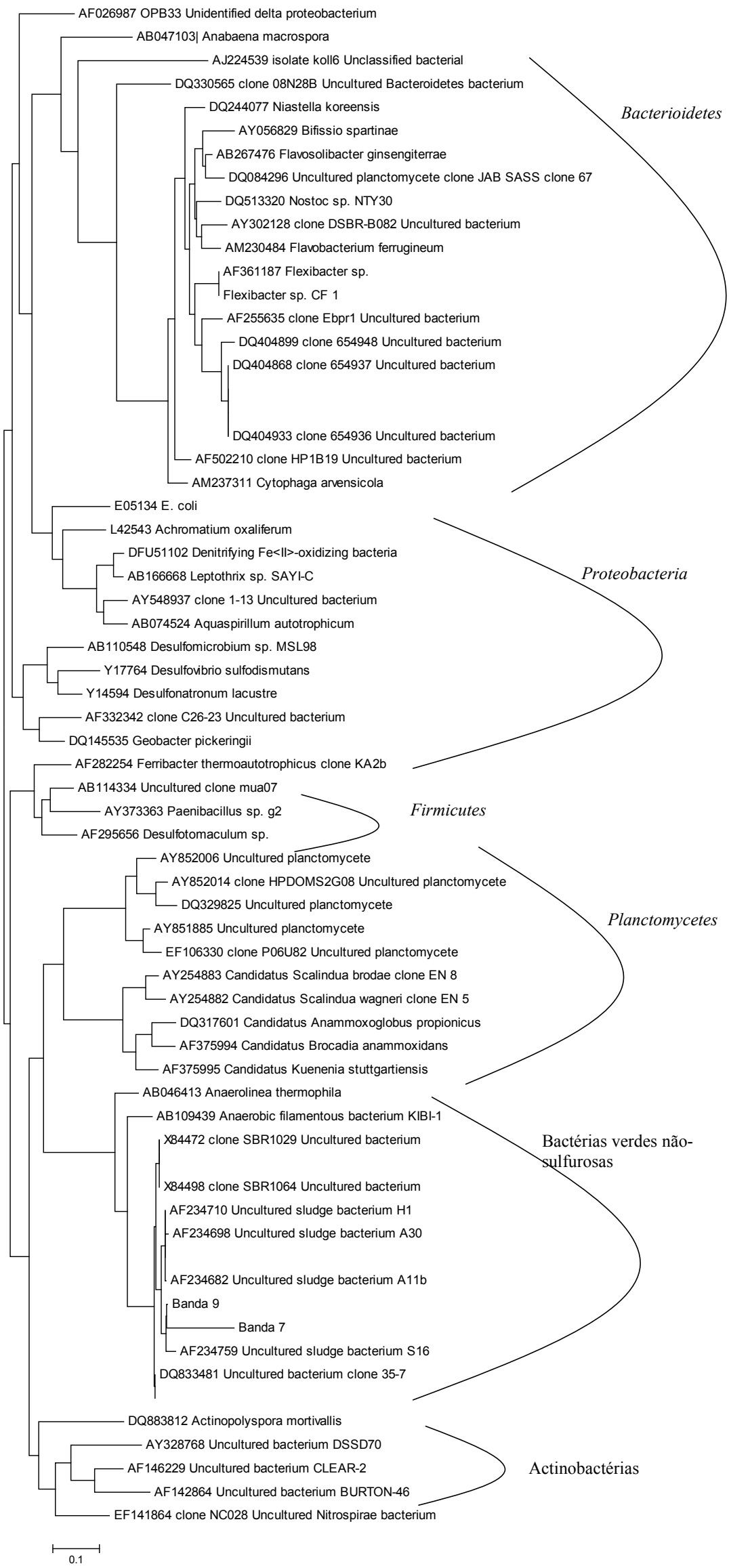

Figura 5.24. Árvore filogenética de máxima verossimilhança do DNA ribossomal 16S, mostrando similaridades entre seqüências obtidas das bandas 7 e 9 e membros do grupo das Bactérias verdes não sulfurosas, filo Planctomyces, Bacterioidetes, Actinobactérias, Firmicutes e Proteobacteria. A barra significa distância filogenética relativa, observada somente horizontalmente, entre dois ramos da árvore. 
A Figura 5.25 mostra árvore filogenética contendo as seqüências 7 e 9, bactérias verdes não-sulfurosas (Chloroflexi) mais relacionadas, bactérias anammox, E. coli e Aquifex aeolicus como grupo externo. Observa-se que as seqüências 7 e 9 agruparam principalmente com os clones S16, A11b, H11, H19 e A30. Esses clones são de seqüências obtidas de reator nitrificante-desnitrificante usado no tratamento de água residuária industrial (Juretschko et al., 2002). No trabalho dos autores op.cit. também é relatada a distância filogenética destes clones com bactérias cultiváveis.

A Figura 5.26 mostra como as seqüências do presente trabalho e as seqüências obtidas por JURETSCHKO et al., 2002 são distantes filogeneticamente das bactérias verdes não sulfurosas cultiváveis.

Os representantes de Proteobacteria (incluindo bactérias púrpuras fotossintéticas), Cytophagales (grupo dos Bacteroides/Cytophaga/Flexibacter) e as duas divisões de organismos Gram-positivos (Actinobacteria e Gram-positivos de baixo conteúdo de $\mathrm{G}+\mathrm{C}$ ), de distribuição cosmopolita são exemplos de organismos bem conhecidos através de representantes cultivados. Em contraste, organismos das Divisões Acidobacterium, bactérias verdes não-sulfurosas (Chloroflexi) e Verrucomicrobium, que também apresentam distribuição cosmopolita, evidenciada por estudos de seqüências de DNAr 16S clonadas do meio ambiente, são pouco representados por organismos cultivados e, conseqüentemente, pouco se sabe sobre a sua biologia e propriedades metabólicas (Hugenholtz et al., 1998).

Bactérias Verdes Não-Sulfurosas formam grupo constituído por organismos com morfologia filamentosa ou cocóide (Sphaerobacter thermophilus), incluindo representantes cultivados com metabolismo fototrófico anóxico (Chloroflexus sp.) e organotrófico termófilo (Herpetosiphon aurantiacus, Sphaerobacter thermophilus e Thermomicrobium roseum). Espécies de Chloroflexus são metabolicamente versáteis, pois podem se desenvolver no escuro, como organismos quimiorganotróficos e sob condições aeróbias por fotoautotrofia $\left(\mathrm{H}_{2} \mathrm{~S}+\mathrm{CO}_{2}\right.$ ou $\left.\mathrm{H}_{2}+\mathrm{CO}_{2}\right)$ (Madigan et al., 2004). Em geral usam compostos orgânicos reduzidos como doadores de elétrons para fixação de $\mathrm{CO}_{2}$.

A diversidade metabólica destes organismos e a ocorrência de organismos nãocultivados em diversos habitats, incluindo aqüíferos, fontes geotermais, ambientes marinhos, sedimentos e solo, e águas residuárias, sugerem que estes organismos possam ter um papel ecológico importante nestes ambientes. Oscillochloris trichoides e Chloronema giganteum podem se desenvolver em lagos de água doce com baixos teores de sulfeto em conjunto com bactérias verdes e púrpuras sulfurosas (Madigan et al., 2004). 
Bactérias verdes nãosulfurosas (Chloroflexi)

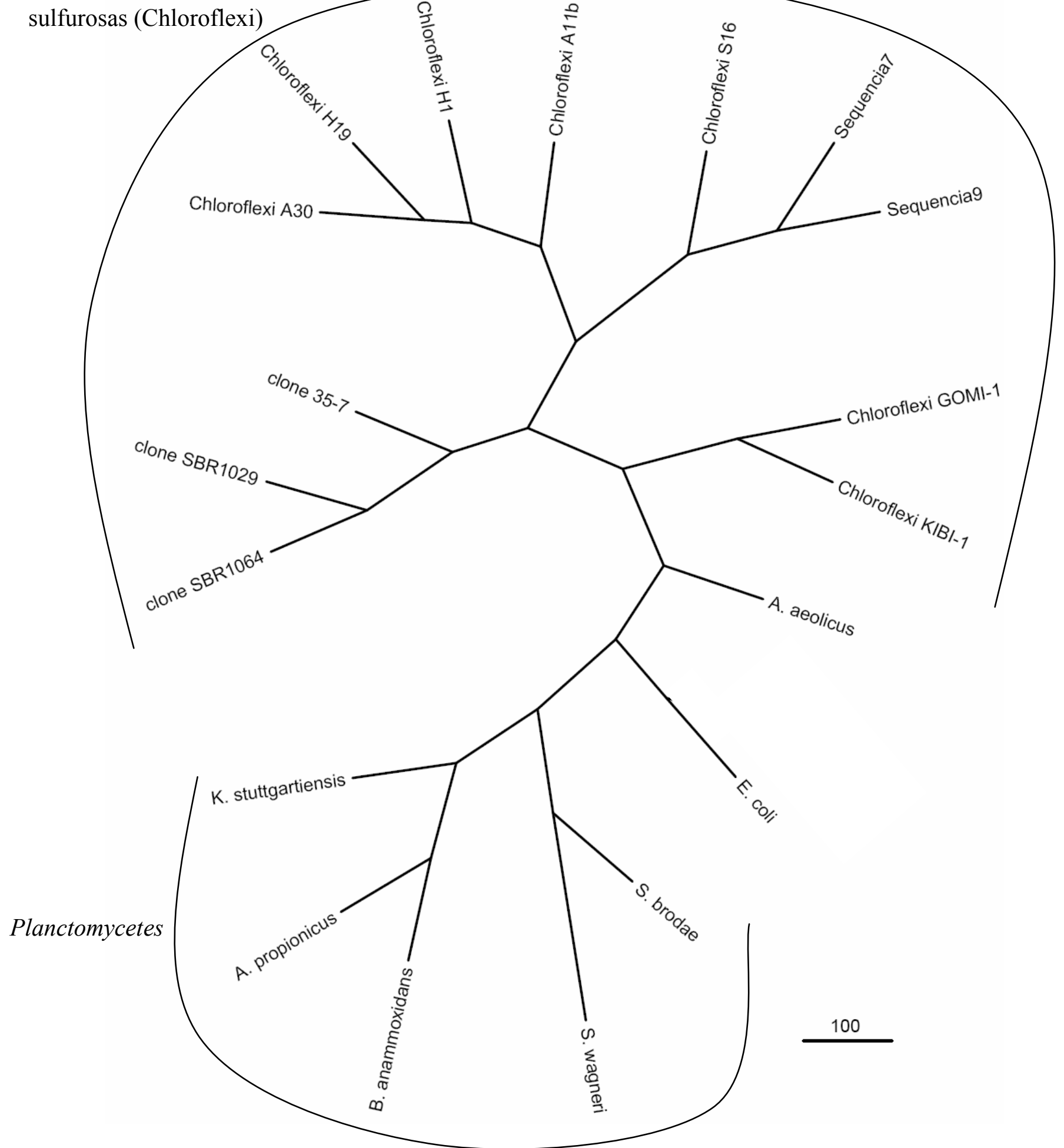

Figura 5.25. Árvore filogenética de máxima verossimilhança do DNA ribossomal 16S das seqüências 7 e 9 em relação ao grupo de bactérias verdes não-sulfurosas (filo Chloroflexi) mais relacionadas, bactérias anammox, E. coli. Aquifex aeolicus foi utilizado como grupo externo. A barra significa distância filogenética relativa entre dois ramos da árvore. 


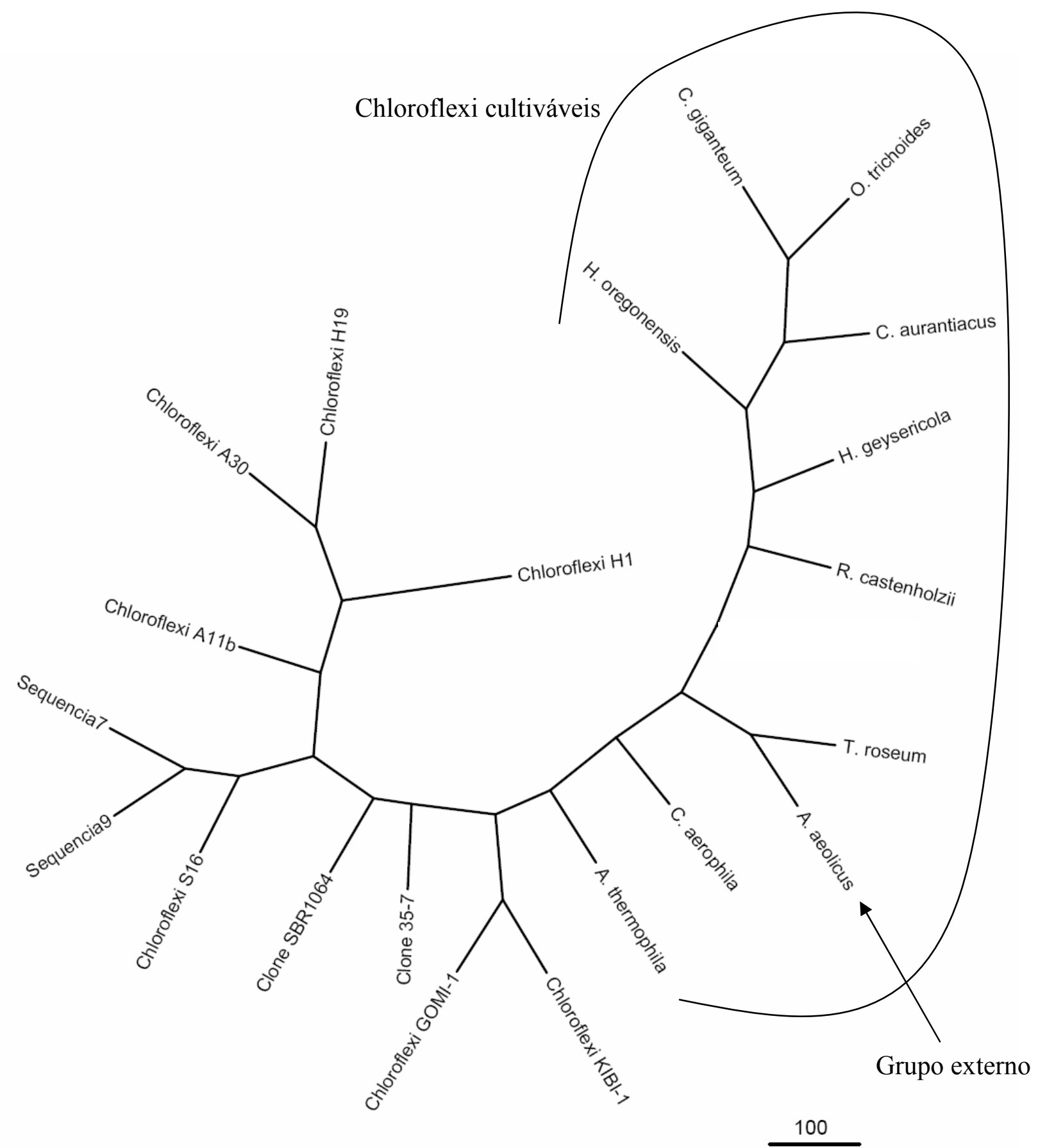

Figura 5.26. Árvore filogenética de máxima verossimilhança do DNA ribossomal 16S das seqüências 7 e 9 em relação ao grupo de bactérias verdes não-sulfurosas (Chloroflexi). Aquifex aeolicus foi utilizado como grupo externo. A barra significa distância filogenética relativa entre dois ramos da árvore. Thermomicrobium roseum é bactéria verde não-sulfurosa de ramificação precoce, por isso agrupou nesta árvore com Aquifex aeolicus (grupo externo).

Provavelmente os filamentos encontrados em microscopia de contraste de fase (Figura 5.7) estão relacionados com grupo de bactérias verdes não sulfurosas. A presença deste grupo no quimiostato (Q2) não é surpreendente, pois as espécies mais relacionadas pela árvore filogenética são Anaerolinea thermophila e Caldilinea aerophila descritas por 
SEQUIGUCHI et al. (2003). Essas duas espécies crescem sob condições fermentativa e fermentativa ou aeróbia, respectivamente. As duas espécies não crescem sob nenhuma condição fototrófica e o substrato preferencial é ácido acético. O ácido acético pode ter sido formado por fermentação, ou desnitrificação de restos celulares e utilizado por bactérias Chloroflexi presente em Q2.

\section{CONCLUSÕES}

Dois quimiostatos foram operados durante 316 dias sob mesmas condições, mas diferindo entre si apenas o inoculo, Q1 - lodo de UASB utilizado no tratamento de água residuária de abatedouro de aves e Q2 - biomassa de reator nitrificante-desnitrificante de indústria produtora de aminoácido. As conclusões obtidas após a operação e monitoramento foram:

- Foi possível enriquecer consórcios microbianos contendo agregados de cocos Gram negativos com morfologia semelhante às bactérias anammox;

- A remoção do nitrogênio amoniacal $\left(\mathrm{N}^{-\mathrm{NH}_{4}}{ }^{+}\right)$foi de $51,3 \pm 13,1 \%$ e $39,3 \pm 14,4 \%$ em Q1 e Q2, respectivamente, na etapa V;

- A remoção de $\mathrm{N}_{-} \mathrm{NO}_{2}^{-}$foi de $60,5 \pm 9,2 \%$ e $53,2 \pm 10,9 \%$ para Q1 e Q2 respectivamente, na etapa $\mathrm{V}$;

- Foi detectado nitrato a partir do $274^{\circ}$ dia de operação demonstrando que o processo anammox ocorreu nos dois quimiostatos;

- O processo anammox foi confirmado por análises físico-químicas e moleculares utilizando-se sondas específicas para microrganismos anammox;

- O quimiostato Q1 obteve eficiência de remoção de nitrogênio total de $57,1 \pm 4,1 \%$, e

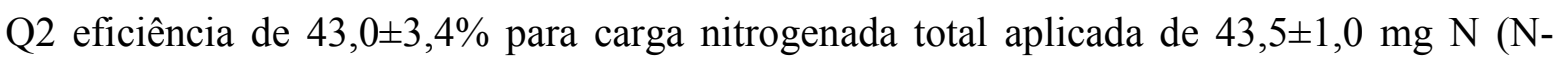
$\left.\mathrm{NO}_{2}{ }^{-}+\mathrm{N}-\mathrm{NH}_{4}{ }^{+}\right) / \mathrm{L}_{\text {reator }}$.dia.

- Análises da estrutura dos consórcios presentes nos dois quimiostatos revelaram algumas populações favorecidas em detrimento a outras não-aptas às condições anammox;

- Duas bandas recuperadas de gel de DGGE situaram-se filogeneticamente próximas às bactérias verdes não-sulfurosas.

\section{RECOMENDAÇÕES FUTURAS}

- Avaliar a comunidade microbiana presente em reatores inoculados com biomassa 
tropical sob condições anammox por clonagem e biblioteca genômica;

- Realizar ensaios de atividade anammox em batelada;

- Realizar ensaios em batelada verificando-se temperatura e pH ótimos para culturas anammox presentes em regiões tropicais; 


\section{REFERÊNCIAS BIBLIOGRÁFICAS}

BAPTESTE, E and GRIBALDO, S. (2003). The genome reduction hypothesis and the phylogeny of eukaryotes. Trends in Genetics 19 (12): 696-700

BRODA, E. (1977). Two kinds of lithotrophs missing in nature. Z. Allg. Mikrobiol. 17: 491-493.

BROSIUS, J.; PALMER, M.L.; KENNEDY, P.J.; NOLLER, H.F. (1978). Complete sequence of a $16 \mathrm{~S}$ ribosomal RNA gene from Escherichia coli. Proc. Natl. Acad. Sci. USA. 75: 4801-4805

BOND, P.L.; HUGENHOLTZ, P.; KELLER, J.; BLACKALL, L.L (1995).Bacterial community structures of Phosphate-Removing and Non-Phosphate-Removing activated sludges from sequencing batch reactors. Appl. Environ. Microbiol 61: 1910-1916

DAPENA-MORA, A.; CAMPOS, J.L.; MOSQUERA-CORRAL, A.; JETTEN, M.S.M.; MÉNDEZ, R. (2004). Stability of the ANAMMOX process in a gas-lift reactor and a SBR. J. Biotech. 100:159-170.

DSM, Scientific Services of Cultures Collections. Curso Ministrado na Fundação Tropical de pesquisa e tecnologia André Toledo. Campinas, 1991.

EGLI, K.; BOSSHARD, F.; WERLEN, C.; LAIS, P.; SIEGRIST, H.; ZEHNDER, A.J.; VAN DER MEER, J.R. (2003). Microbial composition and structure of a rotating biological contactor biofilm treating ammonium-rich wastewater without organic carbon. Microb. Ecol. 45(4): 419-32.

EGLI, K.; FANGER, U.; ALVAREZ, P.J.J.; SIEGRIST, H.; VAN DER MEER, J.R.; ZEHNDER, A.J. (2001) Enrichment and characterization of an anammox bacterium from a rotating biological contactor treating ammonium-rich leachate. Arch. Microbiol. 175: 198-207.

FUEST, J.A. (1995). The planctomicetes: emerging models for microbial ecology, evolution and cell biology. Microbiology UK 141: 1493-1506.

HUGENHOLTZ, P.; GOEBEL, B.M.; PACE, N.R. (1998). Impact of CultureIndependent Studies on the Emerging Phylogenetic View of Bacterial Diversity. J. Bacteriol. 180: 4765-4774.

JETTEN, M.S.M.; LOGEMANN, S.; MUYZER, G.; ROBERTSON, L.A.; DEVRIES, S.; VAN LOOSDRECHT, M.C.M.; KUENEN, J.G. (1997). Novel principles in the microbial conversion of nitrogen compounds. Antonie van Leeuwenhoek 71: 75-93.

JETTEN, M.S.M.; STROUS, M.; VAN DE PAS-SCHOONEN, K.T.; SCHALK, J.; 
VAN DONGEN, U.G.J.M.; VAN DE GRAAF, A.A.; LOGEMANN, S.; MUYZER, G.; VAN LOOSDRECHT, M.C.M.; KUENEN, J.G. (1999). The anaerobic oxidation of ammonium. FEMS Microbiol. Rev. 22: 421-437.

JETTEN M.S.M.; WAGNER, M.; FUERST, J.; VAN LOOSDRECHT, M.C.M.; KUENEN, J.G.; STROUS, M. (2001a). Microbiology and application of the anaerobic ammonium oxidation ('anammox') process. Curr. Opin. Biotechnol. 12: 283-288.

JETTEN, M. S. M.; VAN DONGEN, L. G. J. M.; VAN LOOSDRECHT, M. C. M (2001b). “The Combined Sharon/Anammox Process". Stowa: Foundation for Applied Water Research. IWA Publishing. London.

JETTEN, M.S.M.; SLIEKERS, A.O.; KUYPERS, M.M.M.; THAMDRUP, B.; VAN NITFRIK, L.; CIRPUS, I.; VAN DE PAS-SCHOONEN, K.T.; LAVIK, G.; DALSGAARD, T.; WAGNER, M.; SINNINGHE-DAMSTÉ, J.S.; JØRGENSEN, B.B.; KUENEN, J.G.; FUERST, J.; SCHMID, M.; STROUS, M; (2003). Anaerobic ammonium oxidation by marine and freshwater planctomycete-like bacteria. Appl. Microbiol. Biotechnol. 63: 107114.

JIANLONG, W.; JING, K. (2005). The characteristics of anaerobic ammonium oxidation (ANAMMOX) by granular sludge from an EGSB reactor. Process Biochemistry 40 (5): 1973-1978.

JONES, M.L.; LIEHR, S.K.; CLASSEN, J.J.; ROBARGE, W. (2000). Mechanisms of dinitrogen gas formation in anaerobic lagoons. Advan. Environ. Res. 4: 133-139.

JURETSCHKO, S.; LOY, ALEXANDER.; LEHNER, A.; WAGNER, M. (2002). The Microbial Community Composition of a Nitrifying-Denitrifying Activated Sludge from an Industrial Sewage Treatment Plant Analyzed by the Full-Cycle rRNA Approach. Syst. Appl. Microbiol. 25 (1): 84-99.

KARTAL, B.; RATTRAY, J.; VAN NIFTRIK, L.A.; VAN DE VOSSENBERG, J.; SCHMID, M.C.; WEBB, R.I.; SCHOUTEN, S.; FUERST, J.A.; SINNINGHE DAMSTE, J.; JETTEN, M.S.M; STROUS, M. (2007). Candidatus “Anammoxoglobus propionicus” a new propionate oxidizing species of anaerobic ammonium oxidizing bacteria. Syst. Appl. Microbiol. 30: 39-49.

KIELING. DD. (2004). Estudo da remoção biológica de nitrogênio a partir de lodo nitrificante cultivado em meio autotrófico sob condições anóxicas. Dissertação de mestrado. Universidade Federal de Santa Catarina.

KIELING. D.D.; REGINATTO, V.; SCHMIDELL, W.; TRAVERS, D.; MENES, R.J.; SOARES, H.M. (2005). Influence of sludge wash-out on the establishment of 
anammox process. Proceedings of Anaerobic Digestion (DAAL). Uruguai 5 a 8 de outubro de 2005 .

KUYPERS, M.M.M.; SLIEKERS, A.O.; LAVIK, G.; SCHMID, M.; JØRGENSEN, B.B.; KUENEN, J.G.; SINNINGHE-DAMSTÉ, J.S.; STROUS, M.; JETTEN, M.S.M.; SCHMIDT, I. (2003). Anaerobic ammoniun oxidation by anammox bacteria in the Black sea. Nature 422: 608-611.

LINDSAY, M.R.; WEBB, R.I.; STROUS, M.; JETTEN, M.S.M.; BUTLER, M.K.; FORDE, R.J.; FUERST, J.A. (2001). Cell compartmentalisation in planctomycetes: novel types of structural organization for the bacterial cell. Arch. Microbiol. 175: 413-429.

MADIGAN, M. T; MARTINKO, J. M; \& PARKER, J. (2004). Brock BIOLOGY of MICROORGANISMS. $10^{\mathrm{a}}$ edição New Jersey, Printice Hall.

MELVIN, A.N.W.T.; HOBSON, P.P. (1994). Identification of anaerobic digester bacteria using polimerase chain reaction method. Bioresource Technology 47: 73-80.

MULDER, A.; VAN DE GRAAF, A.A.; ROBERTSON, L.A.; KUENEN, J.G. (1995). Anaerobic ammonium oxidation discovered in a denitrifying fluidized bed reactor. FEMS Microb. Ecol. 16: 177-183.

NEEF, A; AMAN, R; SCHLESNER, H \& SCHLIEFER, KH (1998). Monitoring a widespread bacterial group: in situ detection of planctomicetes with $16 \mathrm{~S}$ rRNA-targets probes. Microbiology UK 144: 3257-3266.

NIELSEN, AT; LIU, WT; FILIPE, C; GRADY, L; MOLIN, S; STAHL, DA. (1999). Identification of a novel group of bacteria in sludge from a deteriorated biological phosphorus removal reactor. Appl. Environ. Microbiol. 65 1251-1258.

SCHMID, M.; WALSH, K.; WEBB, R.I.; RIJPSTRA, W.I.C.; VAN DE PASSCHOONEN, K.T.; VERBRUGGEN, M.J.; HILL, T.; MOFFERT, B.; FUERST, J.A.; SCHOUTEN, S.; SINNINGHE DAMSTÉ, J.S.; HARRIS, J.; SHAW, P.; JETTEN, M.S.M.; STROUS, M. (2003). Candidatus "Scalindua brodae", sp. Nov., Candidatus "Scalindua wagneri", sp. Nov., Two New Species of Anaerobic Ammonium Oxidizing Bacteria. Syst. Appl. Microbiol. 26: 529-538.

SCHMID, M.; TWACHTMANN, U.; KLEIN, M.; STROUS, M.; JURETSCHKO, S.; JETTEN, M.S.M.; METZGER, J.W.; SCHLEIFER, K.H.; WAGNER, M. (2000). Molecular evidence for genus level diversity of bacteria capable of catalyzing anaerobic ammonium oxidation. Syst. Appl. Microbiol. 23 (1): 93-106

SCHMIDT, I; SLIEKERS, O; SCHMID, M; BOCK, E; FUERST, JA; KUENEN, JG; JETTEN, MSM; STROUS, M (2003). New concepts of microbial treatment processes 
for the nitrogen removal in wastewater. FEMS Microbiol. Rev 27: 481-492.

SEKIGUCHI, Y.; YAMADA, T.; HANADA, S.; OHASHI, A.; HARADA, H.; KAMAGATA, Y. (2003). Anaerolinea thermophila gen. nov., sp. nov. and Caldilinea aerophila gen. nov., sp. nov., novel filamentous thermophiles that represent a previously uncultured lineage of the domain Bacteria at the subphylum level. Int. J. Syst. and Evol. Microbiology 53: 1843-1851.

SINNINGHE-DAMSTE, J.S.; STROUS, M.; RIJPSTRA, W.I.; HOPMANS, E.C.; GEENEVASEN, J.A.J.; VAN DUIN, A.C.T.; VAN NIFTRIK, L.A.; JETTEN, M.S.M. (2002). Linearly concatenated cyclobutane (ladderane) lipids form a dense bacterial membrane. Nature 419: 708-712.

Standard Methods for the Examination of Water and Wastewater. (1998). $20^{\text {th }}$ ed. American Public Heath Association/American Water Works Association/Water Environment Federation, Washington, DC, USA.

STROUS, M.; VAN GERVEN, E.; KUENEN, J.G.; JETTEN, M.S.M. (1997a) Effects of aerobic and microaerobic conditions on anaerobic ammonium-oxidizing (Anammox) sludge. Appl. Environ. Microbiol. 63: 2446-2448.

STROUS, M.; VAN GERVEN, E.; PING, Z.; KUENEN, J.G.; JETTEN, M.S.M. (1997b). Ammonium removal from concentrated waste streams with the Anaerobic Ammonium Oxidation (Anammox) process in different reactor configurations. Wat. Res. 31: 1955-1962.

STROUS, M.; HEIJNEN, J.J.; KUENEN, J.G.; JETTEN, M.S.M. (1998). The sequencing batch reactor as a powerful tool for the study of slowly growing anaerobic ammonium-oxidizing microorganisms. Appl. Microbiol. Biotechnol. 50: 589-596.

STROUS, M.; FUERST, J.A.; KRAMER, E.H.M.; LOGEMANN, S.; MUYZER, G.; VAN DE PAS-SCHOONEN, K.T.; WEBB R.; KUENEN, J.G.; JETTEN, M.S.M. (1999a). Missing lithotroph identified as new planctomycete. Nature 400: 446-449.

STROUS, M.; KUENEN, J.G. \& JETTEN, M.S.M. (1999b). Key physiology of anaerobic ammonium oxidation. Appl. Environ. Microbiol. 65: 3248-3250.

STROUS, M.; KUENEN, J.G.; FUERST, J.A.; WAGNER, M.; JETTEN, M.S.M. (2002). The anammox case - A new experimental manifesto for microbiological ecophysiology. Antonie van Leeuwenhoek 81: 693-702.

STROUS, M.; PELLETIER, E.; MANGENOT, S. (2006). Deciphering the evolution and metabolism of an anammox bacterium from a community genome. Nature 440: 790794. 
THAMDRUP, B.; DALSGAARD, T. (2002). Production of N2 through Anaerobic Ammonium Oxidation Coupled to Nitrate Reduction in Marine Sediments. Appl. Environ. Microbiol. 68: 1312-1318.

TOH, S.K.; WEBB, R.I.; ASHBOLT, N.J. (2002). Enrichment of autotrophic anaerobic ammonium-oxidizing consortia from various wastewaters. Microb. Ecol. 43:154167.

VAN DE GRAAF, A.A.; DE BRUIJN, P.; ROBERTSON, L.A.; JETTEN, M.S.M.; KUENEN, J.G. (1996). Autotrophic growth of anaerobic ammonium-oxidizing microorganisms in a fluidized bed reactor. Microbiology UK 142: 2187-2196.

VAN DE GRAAF, A.A.; DE BRUIJN, P.; ROBERTSON, L.A.; JETTEN, M.S.M.; KUENEN, J.G. (1997). Metabolic pathway of anaerobic ammonium oxidation on the basis of N-15 studies in a fluidized bed reactor. Microbiology UK 143: 2415-2421.

VAN DE GRAAF, A.A.; MULDER, A.; BRUIJN, P.; JETTEN, M.S.M.; ROBERTSON, L.A.; KUENEN, J.G. (1995). Anaerobic oxidation of ammonium is a biologically mediated process. Appl. Environ. Microbiol. 61: 1246-1251.

VERSTRAETE, W .; PHILIPS, S. (1998). Nitrification-denitrification processes and technologies in new contexts. Environmental Pollution 102: 717-726. 


\section{Anexo}

Tabela 1. Valores das concentrações de nitrogênio amoniacal monitorados em Q1 e Q2.

\begin{tabular}{|c|c|c|c|c|c|}
\hline $\begin{array}{l}\text { Operação } \\
\text { (dias) }\end{array}$ & $\begin{array}{c}\text { Afluente } \\
\left(\mathrm{mg} \mathrm{N}^{-\mathrm{NH}_{4}}{ }^{+} / \mathrm{L}\right)\end{array}$ & 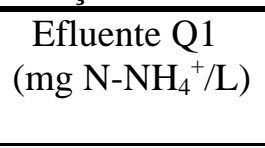 & $\begin{array}{c}\text { Efluente Q2 } \\
\left(\mathrm{mg} \mathrm{N}^{+}\right. \\
\left.\mathrm{NH}_{4}^{+} / \mathrm{L}\right) \\
\end{array}$ & $\begin{array}{c}\text { Eficiência de } \\
\text { remoção Q1 } \\
(\%)\end{array}$ & $\begin{array}{l}\text { Eficiência de } \\
\text { remoção Q2 } \\
(\%)\end{array}$ \\
\hline 17 & 74,1 & 47,7 & 39,9 & 35,6 & 46,2 \\
\hline 24 & 76,9 & 54,6 & 38,8 & 29,0 & 49,5 \\
\hline 30 & 60,1 & 55,8 & 39,9 & 7,2 & 33,6 \\
\hline 48 & 48,4 & 39,3 & 37,9 & 18,8 & 21,7 \\
\hline 56 & 66,3 & 49,1 & 49,1 & 25,9 & 25,9 \\
\hline 61 & 71,2 & 52,8 & 50,5 & 25,8 & 29,1 \\
\hline 70 & 57,1 & 38,1 & 29,6 & 33,3 & 48,2 \\
\hline 73 & 69,8 & 52,9 & 50,8 & 24,2 & 27,2 \\
\hline 87 & 60,1 & 32,6 & 31,3 & 45,8 & 47,9 \\
\hline 91 & 55,8 & 33,8 & 29,6 & 39,4 & 47,0 \\
\hline 116 & 61,3 & 45,7 & 43,6 & 25,4 & 28,9 \\
\hline 123 & 51,2 & 30,5 & 34,7 & 40,4 & 32,2 \\
\hline 136 & 73,2 & 48,2 & 50,3 & 34,2 & 31,3 \\
\hline 138 & 63,5 & 47,8 & 49,5 & 24,7 & 22,0 \\
\hline 144 & 65,1 & 46,5 & 47,4 & 28,6 & 27,2 \\
\hline 147 & 65,6 & 47,4 & 47,4 & 27,7 & 27,7 \\
\hline 157 & 63,9 & 50,8 & 47,4 & 20,5 & 25,8 \\
\hline 161 & 62,2 & 50,2 & 49,2 & 19,3 & 20,9 \\
\hline 165 & 67,5 & 45,3 & 51,2 & 32,9 & 24,1 \\
\hline 170 & 65,2 & 46,4 & 45,3 & 28,8 & 30,5 \\
\hline 175 & 68,4 & 46,2 & 44,8 & 32,5 & 34,5 \\
\hline 180 & 65,3 & 47,2 & 42,1 & 27,7 & 35,5 \\
\hline 187 & 67,8 & 45,6 & 43,2 & 32,7 & 36,3 \\
\hline 194 & 68,1 & 44,9 & 45,6 & 34,1 & 33,0 \\
\hline 200 & 67 & 41,2 & 41,8 & 38,5 & 37,6 \\
\hline 203 & 62,8 & 44,1 & 42 & 29,8 & 33,1 \\
\hline 209 & 60,1 & 43,6 & 43,7 & 27,5 & 27,3 \\
\hline 218 & 68,9 & 47,4 & 46,9 & 31,2 & 31,9 \\
\hline $220 *$ & 62,7 & 58,4 & 58,2 & 6,9 & 7,2 \\
\hline $224 *$ & 65,7 & 62 & 59,9 & 5,6 & 8,8 \\
\hline $227 *$ & 69,9 & 58,2 & 59,4 & 16,7 & 15,0 \\
\hline $232 *$ & 68,3 & 61,1 & 60,2 & 10,5 & 11,9 \\
\hline $236 * *$ & 68,2 & 61 & 45,2 & 10,6 & 33,7 \\
\hline $239 * *$ & 71,2 & 69 & 49,4 & 3,1 & 30,6 \\
\hline $241 * *$ & 72,1 & 64,7 & 45,2 & 10,3 & 37,3 \\
\hline $243 * *$ & 67,3 & 63,1 & 43 & 6,2 & 36,1 \\
\hline $247 * *$ & 27,4 & 48,4 & 24,3 & $-76,6$ & 11,3 \\
\hline 252 & 85,6 & 62,9 & 60,9 & 26,5 & 28,9 \\
\hline 255 & 74,2 & 31,2 & 20,8 & 58,0 & 72,0 \\
\hline 262 & 71 & 33,2 & 42,7 & 53,2 & 39,9 \\
\hline 268 & 82,9 & 59,6 & 49,8 & 28,1 & 39,9 \\
\hline 274 & 82,4 & 55,8 & 66,2 & 32,3 & 19,7 \\
\hline 276 & 82,9 & 40,6 & 57,8 & 51,0 & 30,3 \\
\hline 282 & 80,7 & 38,5 & 57,1 & 52,3 & 29,2 \\
\hline 288 & 81,0 & 29,7 & 46,7 & 63,3 & 42,3 \\
\hline 292 & 77,3 & 28,9 & 45,1 & 62,6 & 41,7 \\
\hline 296 & 75,9 & 27,6 & 46,3 & 63,6 & 39,0 \\
\hline
\end{tabular}

* período alimentado com afluente contendo somente amônia.

** período que ocorreu nitrificação nas mangueiras de alimentação. 
Tabela 2. Valores das concentrações de nitrogênio na forma de nitrito monitorados em Q1 e Q2.

\begin{tabular}{|c|c|c|c|c|c|}
\hline $\begin{array}{l}\text { Operação } \\
\text { (dias) }\end{array}$ & $\begin{array}{c}\text { Afluente } \\
\left(\mathrm{mg} \mathrm{N}-\mathrm{NO}_{2}^{-} / \mathrm{L}\right)\end{array}$ & $\begin{array}{c}\text { Efluente Q1 } \\
\left(\mathrm{mg} \mathrm{N}-\mathrm{NO}_{2}^{-} / \mathrm{L}\right)\end{array}$ & $\begin{array}{c}\text { Efluente Q2 } \\
\left(\mathrm{mg} \mathrm{N}-\mathrm{NO}_{2}^{-} / \mathrm{L}\right)\end{array}$ & $\begin{array}{l}\text { Eficiência de } \\
\text { remoção Q1 } \\
(\%)\end{array}$ & $\begin{array}{c}\text { Eficiência de } \\
\text { remoção Q2 } \\
(\%)\end{array}$ \\
\hline 17 & 79,0 & 3,5 & 16,3 & 95,5 & 79,4 \\
\hline 21 & 71,2 & 19,0 & 11,2 & 73,4 & 84,3 \\
\hline 24 & 67,2 & 26,2 & 25,9 & 61,0 & 61,5 \\
\hline 30 & 89,3 & 59,3 & 91,8 & 33,5 & $-2,8$ \\
\hline 48 & 92,9 & 90,9 & 98,6 & 2,2 & $-6,2$ \\
\hline 56 & 76,3 & 78,0 & 79,6 & $-2,3$ & $-4,3$ \\
\hline 70 & 75,4 & 90,0 & 104,9 & $-19,4$ & $-39,2$ \\
\hline 73 & 82,0 & 96,3 & 106,1 & $-17,5$ & $-29,4$ \\
\hline 74 & 77,8 & 67,7 & 73,4 & 13,0 & 5,7 \\
\hline 84 & 85,4 & 100,3 & 107,2 & $-17,5$ & $-25,5$ \\
\hline 91 & 79,1 & 82,5 & 84,0 & $-4,3$ & $-6,2$ \\
\hline 116 & 77,4 & 82,2 & 82,5 & $-6,3$ & $-6,7$ \\
\hline 123 & 65,6 & 76,2 & 73,4 & $-16,2$ & $-11,8$ \\
\hline 136 & 64,7 & 44,9 & 45,9 & 30,5 & 29,0 \\
\hline 138 & 69,7 & 42,7 & 45,6 & 38,7 & 34,6 \\
\hline 144 & 71,7 & 8,8 & 11,5 & 87,7 & 83,9 \\
\hline 147 & 70,1 & 13,1 & 23,7 & 81,3 & 66,1 \\
\hline 157 & 71,2 & 15,6 & 21,2 & 78,1 & 70,2 \\
\hline 161 & 70,6 & 17,2 & 14,7 & 75,6 & 79,2 \\
\hline 165 & 78,2 & 19,8 & 16,0 & 74,7 & 79,5 \\
\hline 170 & 71,6 & 16,9 & 15,2 & 76,4 & 78,8 \\
\hline 175 & 70,1 & 17,3 & 18,3 & 75,3 & 73,9 \\
\hline 180 & 74,1 & 21,3 & 12,1 & 71,3 & 83,7 \\
\hline 187 & 72,3 & 21,1 & 16,4 & 70,8 & 77,3 \\
\hline 194 & 71,2 & 16,8 & 18,2 & 76,4 & 74,4 \\
\hline 200 & 68,7 & 18,3 & 21,3 & 73,4 & 69,0 \\
\hline 203 & 67,0 & 15,9 & 19,3 & 76,3 & 71,2 \\
\hline 209 & 68,9 & 16,3 & 17,2 & 76,3 & 75,0 \\
\hline 218 & 70,5 & 24,1 & 18,3 & 65,8 & 74,0 \\
\hline $220 *$ & 0,0 & 7,2 & 8,1 & 0,0 & 0,0 \\
\hline $224^{*}$ & 0,0 & 3,4 & 2,9 & 0,0 & 0,0 \\
\hline $227^{*}$ & 0,0 & 0,0 & 0,0 & 0,0 & 0,0 \\
\hline $232^{*}$ & 0,0 & 0,0 & 0,0 & 0,0 & 0,0 \\
\hline $236^{\star *}$ & 71,0 & 15,1 & 21,7 & 78,7 & 69,4 \\
\hline $239 * *$ & 81,5 & 15,0 & 20,9 & 81,6 & 74,4 \\
\hline $241^{\star \star}$ & 89,2 & 54,3 & 42,6 & 39,2 & 52,2 \\
\hline $243^{\star \star}$ & 105,1 & 79,7 & 93,5 & 24,1 & 11,0 \\
\hline $247^{\star \star *}$ & 111,9 & 82,1 & 99,2 & 26,6 & 11,3 \\
\hline 252 & 75,0 & 58,9 & 69,1 & 21,6 & 7,9 \\
\hline 255 & 70,2 & 47,6 & 39,7 & 32,2 & 43,4 \\
\hline 262 & 71,2 & 52,1 & 41,2 & 26,8 & 42,1 \\
\hline 268 & 63,9 & 62,1 & 60,9 & 2,8 & 4,6 \\
\hline 274 & 72,4 & 16,4 & 18,1 & 77,4 & 75,0 \\
\hline 276 & 74,1 & 29,6 & 36,3 & 60,1 & 51,0 \\
\hline 282 & 69,9 & 33,4 & 36,8 & 52,2 & 47,4 \\
\hline 288 & 71,2 & 34,1 & 38,2 & 52,1 & 46,3 \\
\hline 292 & 78,2 & 30,1 & 37,8 & 61,5 & 51,7 \\
\hline 296 & 85,1 & 34,4 & 44,5 & 59,6 & 47,7 \\
\hline
\end{tabular}

* período alimentado com afluente contendo somente amônia.

** período que ocorreu nitrificação nas mangueiras de alimentação. 